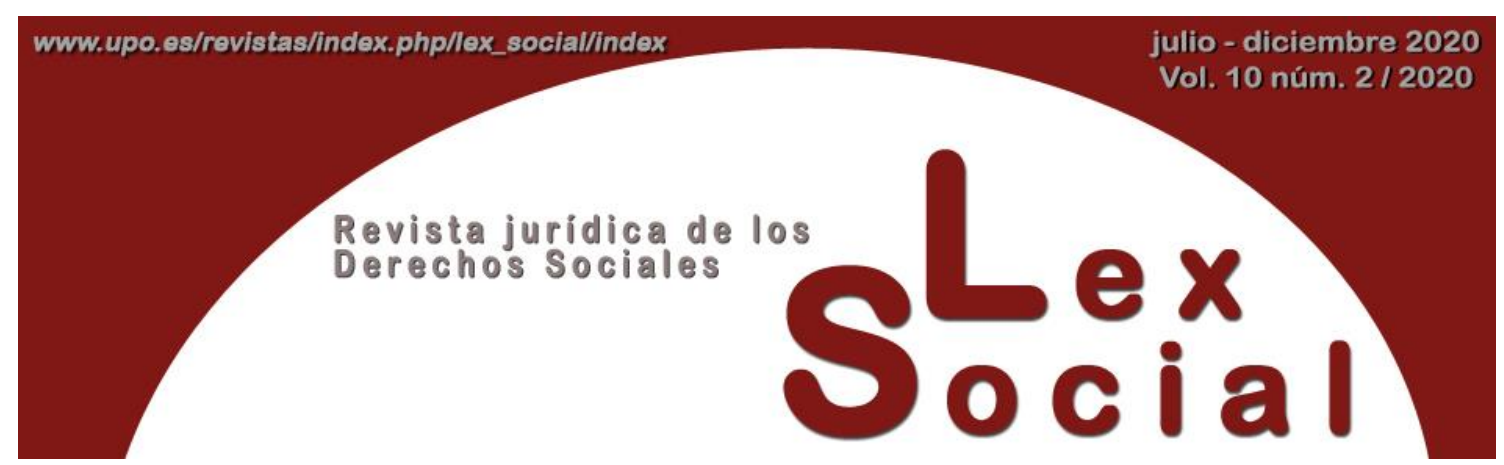

\title{
LA RENTA MÍNIMA GARANTIZADA COMO MEDIDA ESTRUCTURAL DEL SISTEMA DE SEGURIDAD SOCIAL EN LA "SOCIEDAD DEL RIESGO"
}

\section{MINIMUM INCOME GUARANTEED AS A STRUCTURAL MEASURE OF THE SOCIAL SECURITY SYSTEM IN THE "RISK SOCIETY”}

JOSÉ LUIS MONEREO PEREZ

Catedrático de Derecho del Trabajo y de la Seguridad Social

Universidad de Granada. Presidente de la Asociación Española de Salud y Seguridad Social (AESS) ${ }^{1}$

\section{RESUMEN}

La pobreza severa y la expansión de las situaciones de exclusión social y la desestandarización de las carreras y trayectorias del empleo y del aseguramiento han determinado la creación jurídica de diversos mecanismos de mínimos garantizados de ingresos condicionados, cuya fórmula más generalizada -aunque con distintas denominaciones técnicas de instrumentalización o materialización jurídica- ha sido la renta mínima, la cual combina una doble lógica reparadora y de reinserción profesional. Los mecanismos o instrumentos de protección tradicionales se muestran insuficientes. Pero en España el modelo vigente es invertebrado y falto de homogeneidad y racionalización en todos los órdenes (prestaciones, requisitos, modos de gestión, etcétera). Esto ha aconsejado el establecimiento de una renta mínima de nivel estatal, denominada legalmente "Ingreso Mínimo Vital".

\footnotetext{
${ }^{1}$ Director de la Revista de Derecho de la Seguridad Social Laborum.
} 
Palabras Clave: Seguridad Social, Seguridad Social no contributiva, Asistencia Social, rentas mínimas, ingreso mínimo vital, derechos sociales de la ciudadanía, derecho a la existencia digna, derecho al trabajo "decente" o digno, derecho a la reinserción profesional, Estado Social de Derecho, principios constitucionales de solidaridad social, justicia social e igualdad sustancial, pobreza absoluta o relativa, marginalidad, exclusión social, vulnerabilidad, desventaja social, nueva cuestión social.

\begin{abstract}
Severe poverty and the expansion of situations of social exclusion and the de-state of employment and employment and ensuring trajectories have determined the legal creation of various mechanisms of guaranteed minimum conditional income, the most widespread formula of which - albeit with different technical designations of instrumentalization or legal materialization - has been the minimum income, which combines a double restorative logic and reintegration Professional. Traditional protection mechanisms or instruments are insufficient. But in Spain the current model is invertebrate and lacking in homogeneity and rationalization in all orders (performances, requirements, management modes, etc.). This has advised the establishment of a state-level minimum income, legally referred to as "Minimum Vital Income".
\end{abstract}

KEYWORDS: Social Security, non-contributory social security, social assistance, minimum income, minimum living income, social rights of citizenship, right to decent existence, right to "decent" or decent work, right to professional reintegration, Social State of law, constitutional principles of social solidarity, social justice and substantial equality, absolute or relative poverty, marginality, social exclusion, vulnerability, social disadvantage, new social issue.

\title{
SUMARIO
}

Introducción.

1. Fenómenos disruptivos: la incidencia de la nueva revolución industrial, el derecho a la existencia y el futuro social.

2. Desestructuración del trabajo y exclusión social: las deficiencias de los dispositivos de protección social clásicos en la nueva era de la economía digital.

3. Identificación jurídica de las rentas de subsistencia.

3.1. La renta mínima de inserción como derecho subjetivo condicionado.

3.2. La renta básica garantizada o ingreso básico de ciudadanía como derecho subjetivo universal incondicionado.

3.3. Del derecho a la renta mínima condicionada al derecho a la renta básica universalista e incondicionada: ¿Una transición posible? 
4. El modelo español desvertebrado de rentas mínimas de inserción o de renta garantizada de ciudadanía en el Estado Social Autonómico.

5. El Ingreso Mínimo Vital como renta mínima dentro del Sistema institucional de la Seguridad Social No Contributiva.

5.1. El problema social subyacente como telón de fondo.

5.2. Rasgos fundamentales del Ingreso Mínimo Vital.

6. Balance y perspectivas y propuestas de mejora en el plano técnico-jurídico y de política del Derecho.

Bibliografía

[El derecho a la existencia] Todo miembro de la sociedad tiene derecho a que los bienes y los servicios necesarios para la conservación de su existencia, le sean proporcionados"

ANTON MENGER ${ }^{2}$

\section{Introducción}

La pobreza severa y la expansión de las situaciones de exclusión social y la desestandarización de las carreras y trayectorias del empleo y del aseguramiento han determinado la creación jurídica de diversos mecanismos de mínimos garantizados de ingresos condicionados, cuya fórmula más generalizada -aunque con distintas denominaciones técnicas de instrumentalización o materialización jurídica- ha sido la renta mínima, la cual combina una doble lógica reparadora y de reinserción profesional. Los mecanismos o instrumentos de protección tradicionales se muestran insuficientes. Pero en España el modelo vigente es invertebrado y falto de homogeneidad y racionalización en todos los órdenes (prestaciones, requisitos, modos de gestión, etcétera). Esto ha aconsejado el establecimiento de una renta mínima de nivel estatal, denominada legalmente "Ingreso Mínimo Vital". Con la experimentación de este dispositivo de nuevo tipo racionalizador se podría plantear a medio/largo plazo una transición paulatina hacia una medida más ambiciosa -y desde luego más compleja, pero deseable en el plano civilizatorio y de desarrollo del Estado Social de Derecho- como es la instauración de una renta básica universal incondicionada. El reto continúa siendo la lucha jurídica contra la pobreza y la exclusión social y asimismo el derecho a la existencia digna de las personas -en el contexto de convivencia donde se desarrolla su personalidadpuedan tener una vida digna y participar activamente en la comunidad o sociedad

\footnotetext{
${ }^{2}$ MENGER,A.: El derecho al producto íntegro del trabajo \& El Estado democrático del trabajo, edición y estudio preliminar, "Derechos sociales y Estado democrático social en Anton Menger" (pp. IX-LXXVIII), a cargo de José Luis Monereo Pérez, Granada, Ed. Comares (Col. Crítica del Derecho), 2004, pág. 13.
} 
democrática de pertenencia. Se trata de una cuestión de máxima actualidad, pero que entronca con el mismo origen de los derechos sociales en el marco de la construcción del conjunto de los derechos humanos ${ }^{3}$. La renta mínima es una de las instituciones sociales que están suscitando un mayor debate en el marco de la Unión Europea, donde se ha avanzado una propuesta de Directiva-Marco Europea. El ingreso mínimo vital (IMV) introducido en nuestro País en virtud del Real Decreto-ley 20/2020, de 29 de mayo, constituye una expresión de esta medida de garantía de rentas mínimas bajo el paradigma de la "condicionalidad". Es una medida que ya figuraba en el programa del Gobierno de coalición PSOE y Unidos Podemos, y que la epidemia del Covid-19 no ha hecho sino recomendar y acelerar su establecimiento inmediato.

\section{1.-Fenómenos disruptivos: la incidencia de la nueva revolución industrial, el derecho a la existencia y el futuro social .}

Silenciosamente - pero de manera cada vez más visible- se está asistiendo a una verdadera crisis social que introduce una fractura social en las sociedades contemporáneas. Se está produciendo un incremento extraordinario de las situaciones de desigualdad y una generalización de la inseguridad e incertidumbre sobre la existencia. Se consta la incidencia pérdida de empleos y la desestandarización y precarización de los existentes. Esta realidad social ha determinado una revitalización de una propuesta clásica como son la de las rentas de subsistencia en diversas expresiones y denominaciones (rentas mínimas de inserción condicionada, rentas de ciudadanía o ingreso ciudadano incondicionado, etcétera). También se detecta que las técnicas de protección clásicas se muestran insuficientes para abordar la nueva cuestión social planteada por el desarrollo de las fuerzas productivas (mediatizado por la innovación tecnológica y su utilización el sistema productivo) y su impacto en las empresas y en las formas "atípicas" de trabajo profesional.

De este modo las rentas de subsistencia se plantean como una nueva "fórmula mágica" de la teoría social y de la ciencia jurídica, por utilizar la afortunada expresión de Rudolf Wiethölter ${ }^{4}$, encaminadas a la captación y conformación de las realidades sociales. Pero no es por sí sola la solución a los problemas generados por la desestructuración, la destrucción de puestos de trabajo y los cambios de lo organización de la empresas propiciados por la revolución digital y la robotización de las relaciones económicas. Requiere su inserción en un conjunto más amplio de políticas públicas que garanticen derechos sociales de desmercantilización de las personas que trabajan y de protecciones sociales asociados al empleo y al margen de éste. Y sobre todo exige que una

\footnotetext{
${ }^{3}$ De esta materia me vengo ocupando desde 1996. Véase MONEREO PÉREZ, J.L.: Derechos sociales de la ciudadanía y ordenamiento laboral, Madrid, Ed. Consejo Económico y Social de España, 1996; MONEREO PÉREZ, J.L. y MOLINA NAVARRETE, C.: El derecho a la renta de inserción. Estudio de su régimen jurídico, Granada, Ed. Comares, 1999; MONEREO PÉREZ, J.L.: La renta mínima garantizada. De la renta mínima a la renta básica, Albacete, Ed. Bomarzo, 2018.

${ }^{4}$ WIETHOLTER, R.: Las fórmulas mágicas de la ciencia jurídica, Madrid, Ed. Edersa, 1991.
} 
planificación de la actividad económicas y fiscal que haga económicamente viable todo este conjunto de garantías.

Esta institución actualmente está en el centro del debate tanto es su expresión más débil (renta mínima garantizada) como en su manifestación más fuerte y ambiciosa (renta básica universal e incondicionada).

Es lo cierto que estas expresiones acaban siendo un desarrollo en gran medida coherente con el Estado social evolucionado, siempre y cuando no constituyan una alternativa a la centralidad del trabajo y al pleno empleo como un elemento central de vertebración e integración y cohesión social. Y asimismo siempre que no suponga la sustitución de las prestaciones contributiva de los sistemas de Seguridad Social en el nivel de cobertura alcanzado. En la plasmación de esta institución existen teorías e ideologías diferentes y por ello no puede merecer en sí misma una descalificación en términos generales sin atender a los distintos enfoques y modelos que actualmente se proponen ${ }^{5}$.

Con todo, el debate sobre las rentas mínimas o rentas de subsistencia en sus distintas expresiones está, innegablemente, al orden del día. Así se refleja en los intentos de implantación experimental -más allá de su mayor o menor éxito coyuntural- en países como Finlandia, y su experimentación localizada en Ontario, Groningen, Barcelona, etcétera ${ }^{6}$.

Cabría inquirir sobre si las rentas de subsistencia (incluida la expresión cualificada de la renta básica universal e incondicionada que en sí ha llegado a ser calificada incomprensible e injustificadamente- de neoliberal contra el Estado Social); e igualmente sobre si estas instituciones de sostenibilidad de ingresos garantizados por el Estado se asemejaría a algo así como un "caballo de Troya" del neoliberalismo más rancio en el corazón del Estado Social".

La respuesta ha de ser necesariamente negativa planteada en estos términos. La rentas de subsistencias pueden ser medidas no sólo compatibles sino que más incisivamente sean realizaciones (materializaciones) de la forma evolucionado del Estado social enmarcadas un una redefinición permanente del proyecto de sociedad y del ideal de cobertura que han

\footnotetext{
${ }^{5}$ Un visión sugerente, pero en ciertos aspectos indiferenciada y generalista en la descalificación es la que se mantiene en ALALUD, M.y PRIETO, C.: "La renta universal contra el Estado Social", en Gaceta Social, núm. 31 (2018), quienes afirman que la implantación de una renta básica universal e incondicionada para toda la población supondría la desconexión entre renta y trabajo, rompiendo la centralidad del trabajo como elemento vertebrador de la sociedad. El trabajo regulado y protegido limita al mercado mediante las cotizaciones sociales que colectivizan parte de las riquezas productivas, dando acceso a servicios gratuitos y protección social; en tanto que la renta universal conduce a privatizar la riqueza colectiva para dar efectivo a los individuos. Así, la lógica del Estado Social produce derechos fuera del mercado mientras que la renta universal se dirige a permitir a cada persona participar en la mercado, produciendo la mercantilización de las actividades que aún escapan a su esfera.

${ }^{6}$ Para las experiencias históricas e intentos de implantación referidos particularmente a la figura de la renta básica de ciudadanía o ingreso básico, puede consultarse VAN PARIJS,PH. y VANDERBORGHT,Y.: Ingreso básico. Una propuesta radical para una sociedad libre y una economía sensata, trad. Laura Lecuona y Maia F. Miret, México, 2017; STANDING, G.: La renta básica. Un derecho para todos y para siempre, Epílogo de Daniel Raventós y Davide Casassas, Barcelona, Ediciones de Pasado y Presente, 2018.
} 
de dispensar las protecciones sociales a las personas frente a cambiantes situaciones sociales y estados de necesidad social y políticamente relevantes. Son instituciones que pueden situarse en la lógica del Estado social y ser plenamente compatibles con el empleo garantizado. En este sentido se deben evitar simplificaciones ante la diversidad de ideologías y modelos que se pueden proponer (Algo no enteramente nuevo respecto de los mismos modelos de Estados del Bienestar: Estados del Bienestar democrático-sociales expansivos versus Estados del Bienestar "residuales" y minimalistas). No se olvide el "ideal de cobertura" al que ha de aspirar la Seguridad Social está abierto al tiempo y a la cultura de los derechos se vincula al principio de progresividad consagrado en la Carta Social Europea Revisada (Estrasburgo, 3 de mayo de 1996), al establecer que "Para garantizar el ejercicio efectivo del derecho a la Seguridad Social, las Partes se comprometen: [...] 3 a esforzarse por elevar progresivamente el nivel del régimen de Seguridad Social" (art. 12. "Derecho de la Seguridad Social", apartado 3) 7.

La historicidad de los institutos sociales y jurídicos nos ofrece una útil perspectiva de larga duración. El pensamiento socio-económico de los grandes reformadores de edad moderna se inscribe en una larga tradición cultural de defensa de alguna forma de "renta básica" o "renta mínima garantizada" (Desde posiciones ideológicas diferentes autores como Thomas Paine, Thomas Spence, Charles Fourier, Joseph Charlier, Henry George, e incluso los primeros escritos de Herbert Spencer) para garantizar a todos una existencia digna. Ellos partían de que la tierra era un recurso natural propiedad de todos los hombres, defendían la propiedad común de la tierra. Para ellos la Constitución jurídica de la sociedad tiene que asentarse sobre el principio de igualdad en la libertad, a través de una distribución justa de la riqueza disponible. Sus propuestas de instaurar una renta garantizada (en términos de "renta de subsistencia", "renta agraria", "renta de ciudadanía", etcétera) haría posible el derecho a una existencia digna, compatible con el desarrollo de la persona y el progreso económico, solo concebible también como progreso social propiamente dicho ${ }^{8}$.

Es más, en la historia de la invención de los derechos humanos como derechos jurídicos, las propuestas de las rentas de subsistencia estaban formuladas a la par que el debate sobre el conjunto de los derechos humanos. Un exponente harto significativo lo ello lo representa Robespierre en su Discurso de las Subsistencias (10 de mayo de 1793), poniendo de manifiesto que esta problemática estaba incrustada en los orígenes del debate

\footnotetext{
${ }^{7}$ MONEREO PÉREZ, J.L.: "Derechos a la Seguridad Social (Artículo 12 de la Carta Social Europea Revisada)", en VV.AA.: La garantía multinivel de los derechos fundamentales en el Consejo de Europa. El Convenio Europeo de los Derechos Humanos y la Carta Social Europea, Monereo Atienza, C. y Monereo Pérez, J.L. (Dirs. y Coords.), Granada, ed. Comares, 2017, págs. 629 y sigs.; y en una perspectiva más general abundando en los imprescindibles sistemas de control de cumplimiento, ALFONSO MELLADO, L.C., JIMENA QUESADA,L. y SALCEDO BELTRÁN, M.C.: La jurisprudencia del Comité Europeo de Derechos Sociales frente a la crisis económica, Albacete, Ed. Bomarzo, 2014; MONEREO PÉREZ, J.L.: La metamorfosis del Derecho del Trabajo, Albacete, Ed. Bomarzo, 2017, cap. III, págs. 137 y sigs.

${ }^{8}$ En este sentido MONEREO PÉREZ, J.L.: "Pobreza, trabajo y exclusión social en la larga duración: una reflexión crítica a partir de Henry George”, en Documentación laboral, núm. 83 (2008), págs. 11-109, en particular págs. 95-111.
} 
sobre los derechos de las personas que deberían jurídicamente garantizados. En él se subordina la propiedad privada al "derecho a la existencia"; y en nombre de este derecho social matriz se postula las protecciones sociales necesarias para garantizarlo efectivamente ("la propiedad social"). Su Propuesta de Declaración no prosperó, pero "lo social" no estuvo ausente del debate sobre los derechos que deberían ser proclamados en la naciente Declaración de los Derechos del Hombre. No es baladí hacer notar que la Constitución republicana de 24 de junio de 1793 se abrió con una nueva Declaración de los Derechos del Hombre y del Ciudadano que incorporaba explícitamente los derechos sociales de asistencia, educación y trabajo ${ }^{9}$.

De ahí hacia el viraje secuencia que se opera con la Declaración Universidad de los Derechos Humanos (1948), en cuyo art. 22 se establece que: "Toda persona, como miembro de la sociedad, tiene derecho a la seguridad social, y a obtener, mediante el esfuerzo nacional y la cooperación internacional, habida cuenta de la organización y los recursos de cada Estado, la satisfacción de los derechos económicos, sociales y culturales, indispensables a su dignidad y al libre desarrollo de su personalidad". O el art. 25.1, a cuyo tenor: "Toda persona tiene derecho a un nivel de vida adecuado que le asegure, así como a su familia, la salud y el bienestar, y en especial la alimentación, el vestido, la vivienda, la asistencia médica y los servicios sociales necesarios; tiene asimismo derecho a los seguros en caso de desempleo, enfermedad, invalidez, viudez, vejez y otros casos de pérdida de sus medios de subsistencia por circunstancias independientes de su voluntad"10.

En realidad, convendría recordar la parábola del vino nuevo en odres viejos, porque en esa larga duración lo que se atisba es la necesidad de reformular el contrato social. La inserción de un componente estatutario en el contrato de trabajo (haz de protecciones sociales) dignificó a la condición del trabajador. Pero en la nueva época el dilema reside en reinventar formas equivalentes -y no sustitutorias de las protecciones que giran sobre el empleo- de protección social en una economía cada vez más fragmentada y desmaterializada; formas que deben girar sobre la persona del trabajador y la búsqueda de nuevos mecanismos de inserción.

\footnotetext{
${ }^{9}$ Dos artículos son particularmente emblemáticos en la referida Declaración. El art. 21 ("Las ayudas públicas son una deuda sagrada. La sociedad debe la subsistencia a los ciudadanos desgraciados, ya sea procurándoles trabajo, ya sea proporcionando los medios de existencia a los que no estén en condiciones de trabajar"). Esa idea de "deuda social" enlaza ya con una embrionaria idea de "solidarismo social" de los orígenes. El otro artículo significativo es el art. 22 ("La instrucción es una necesidad para todos. La sociedad debe favorecer con todas sus fuerzas los progresos de la razón pública, y poner la instrucción al alcance de todos los ciudadanos").

${ }^{10}$ Ampliamente, MONEREO PÉREZ, J.L.: La dignidad del trabajador. Dignidad de la persona en el sistema de relaciones laborales, Murcia, ed. Laborum, 2019, Capítulos I (La dignidad de la persona en el sistema multinivel de garantías de los derechos y capacidades humanas) y II (La dignidad del trabajador y trabajo decente).
} 


\section{2.-Desestructuración del trabajo y exclusión social: las deficiencias de los dispositivos de protección social clásicos en la nueva era de la economía digital.}

¿Qué factores determinantes explican que unas medidas tan clásicas como las rentas de subsistencia tengan la extraordinaria actualidad que presente hoy?

En primer lugar, de llamarse la atención sobre la expansión de la pobreza y la exclusión social por el trabajo (su falta y su insuficiencia para garantizar una vida digna de la persona que trabaja y de su las personas que dependen económicamente de ella).

En segundo lugar, es de destacar la incidencia de la cuarta revolución industrial o "era digital", sus efectos en la economía y en el trabajo; pero también el tipo de respuesta regulativa institucional y empresarial que la está modulando y conformando en la esfera social. El desarrollo de las fuerzas productivas (que incluye la tecnología y su innovación) siempre ha sido determinante en el curso de los procesos sociales y en los distintos ámbitos del mundo de la vida ${ }^{11}$.

En tercer lugar, la realidad del envejecimiento de la población sin trabajo o con trabajos precarios o inestables.

Y, por último, la insuficiencia de los instrumentos clásicos de protección social arbitrados por los contemporáneos y necesarios Estados sociales. Esa insuficiencia presenta un carácter estructural y persistente, no simplemente contingente, pues trasciende de las consecuencias y respuestas institucionales a la grave crisis económica de la última década para cuestionar el modelo de organización de las sociedades democráticas situadas en la tradición del constitucionalismo social.

En lo que se refiere a la llamada cuarta revolución industrial, es manifiesto que, en unión con los demás factores causales, está determinando que se operan transformaciones disruptivas de envergadura en la era de la economía digital que además se producen a una gran velocidad (las tecnología disruptivas tienen como base la innovación: Big data, virtualización y cloud, ciberseguridad, realidad virtual y aumentada, blockchain, etcétera $)^{12}$. Ante mutaciones de esta entidad en el mundo del trabajo mediatizado por los cambios tecnológicos los sistemas de protección social tienen que dar una respuesta que sea coherente con la persecución de sus propios fines de proteger a las personas ante las siempre cambiantes situaciones de necesidad relevantes.

La cuarta revolución industrial (Revolución industrial 4.0) va a tener una incidencia en el empleo, tanto en lo relativo a los niveles de empleo como en las formas de empleo. Se

\footnotetext{
${ }^{11}$ HABERMAS, J. Ciencia y técnica como ideología, trad. Manuel Jiménez Redondo Tecnos, Madrid, 1986; y, como es obvio, MARX, K.: Elementos fundamentales para la crítica de la economía política, Madrid, Siglo XXI, 1976; POLANYI, K.: La Gran Transformación. Crítica del liberalismo económico, Madrid, Ed. La Piqueta, 1989.

12 Véanse, por ejemplo, las aportaciones recogidas en el monográfico de Teoría y Derecho. Revista de Pensamiento Jurídico, Economía digital, robotización y relaciones laborales, núm. 23 (2018), Editada por Tirant lo Blanch.
} 
producirán procesos contradictorios de creación y destrucción de empleo, pero también desplazamiento de trabajadores desde las actividades en declive a las nuevas actividades en expansión. El problema es que en muchos aspectos se ha roto con el paradigma teórico de la "destrucción creativa" formulada -no sin cierto optimismo- por el sociólogo alemán Werner Sombart y que después sería popularizada por el economista austriaco Joseph Schumpeter en su libro "Capitalismo, socialismo y democracia" (1942) como hecho central del desarrollo del capitalismo moderno ${ }^{13}$. Su validez hoy día es relativo, y en cualquier caso oscilante y nunca lineal. El tiempo indicará si prevalece el lado positivo del desarrollo o el lado negativo y su incidencia en la vida laboral y en los sistemas de protección social.

Por lo pronto lo que sí se aprecia son cambios sobre el empleo harto significativo: un empleo menos estandarizado; un empleo más fraccionado e inestable donde tienden a expandirse las plataformas digitales (Cabify, Uber, Airbnb o Upwork, etc., con formas de empleo difusas -zonas grisis- entre la autonomía y la subordinación ${ }^{14}$. De ahí su elevada controversia judicial), la llamada economía "colaborativa" (que en general lo es poco por ocultar la realidad de una relación subordinada); el sometimiento de la organización del trabajo y del empleo a transformaciones permanentes y no siempre previsibles, pues suelen estar presididas por la incertidumbre, con la consecuencia de un incremento de la flexibilidad laboral interna y externa; y la tendencia hacia la mercantilización y remercantilización de ámbitos dominados por el empleo público (con flujos y reflujos en este proceso discontinuo). Los efectos también se producen en la esfera de las protecciones sociales dispensadas por la forma política del Estado Social de Derecho, el cual tiene serias dificultades para "gobernar" estos procesos de la era digital (con el impulso de robotización y la inteligencia artificial), pues el problema se centra ante todo en el uso y encauzamiento hacia el interés general de las innovaciones tecnológicas, sin caer en la ingenuidad de oponerse sin más al proceso de transformación tecnológica a modo de un "neo-ludismo", que equivoca la identificación de la instancia de poder determinante (como sucedió en movimiento social e ideológico surgido en la primera Revolución Industrial, que se oponían a los nuevas tecnologías industriales del

\footnotetext{
${ }^{13}$ Igualmente, su otro libro, Teoría del desenvolvimiento económico, trad. J. Prados Arrarte, México-Buenos Aires, $3^{\text {a }}$ ed., 1963, precisamente para Joseph A. Schumpeter, el desarrollo económico está presidido por las innovaciones y los cambios tecnológicos que hacen ver al capitalismo como un proceso de evolución a continuas mutaciones (Así, en el mismo Prólogo a la Edición española del libro, 12 de abril de 1941, pág. 12, y ampliamente, págs. 17 y sigs. y 68 y sigs.). Menos optimismo se puede encontrar en autores como VEBLEN, TH.: Teoría de la empresa de negocios, edición y estudio preliminar, «La teoría de la empresa de negocios de Thorstein Veblen», a cargo de J.L. Monereo Pérez, Granada, Ed. Comares (Colección Crítica del Derecho), 2009; y más ampliamente, MONEREO PÉREZ, J.L.: La teoría crítica social de Thorstein Veblen: sociedad opulenta y empresa de negocios, Granada, Ed. Comares, 2010.

${ }^{14}$ Puede consultarse, GAUTHIER, G. (Coord.): Disrupción, economía compartida y Derecho. Enfoque jurídico multidisciplinario, Uruguay, Fundación de Cultura Universitaria, 2016; MERCADER UGUINA, J.R.: El futuro del trabajo en la era de la digitalización y la robótica, Valencia, Ed. Tirant lo Blanch, 2017; TODOLI SIGNES, A.: El trabajo en la era de la economía colaborativa, Valencia, Ed. Tirant lo Blanch, 2017; SIGNORINI, E.: Il diritto del lavoro nell' economia digitale, Torino, G. Giappichelli Editore, 2018; VICENTE PACHÉS, F.: Ciberacoso en el trabajo, Barcelona, Ed. Atelier, 2018.
} 
momento $\left.{ }^{15}\right)$. Sin caer en ningún tipo de excesos optimistas, se puede limitar las nuevas tecnologías dañinas y aprovechar las innovaciones tecnológicas que puedan ser útiles para el bienestar social y el desarrollo económico. En definitiva para gobernar los cambios tecnológicos en la lógica de las necesidades sociales y de un desarrollo económico sostenible orientado hacia el bienestar de la población y la "justicia social". Y esto no lo crean las nuevas tecnologías en sí mismas, sino las políticas democráticas que se implementan y los actores sociales y económicos implicados en los procesos sociales. No sólo hay que atender al desarrollo de las fuerzas productivas de la sociedad, sino también a la mediación política y jurídica que las gobiernan. Se trata de procurar el buen gobierno del cambio tecnológico y de su incidencia en las diversas esferas de la vida (incluido el mundo del trabajo $)^{16}$. Por lo demás, no existe un vínculo directo entre el desarrollo económico, la distribución de la riqueza y la justicia social ${ }^{17}$.

De este modo el impacto de los cambios tecnológicos en el empleo y en las protecciones sociales, que apuntan hacia una desestructuración del trabajo (precariedad, trabajo atípico, falsos autónomos, des-sindicalización y pérdida de poder de las organizaciones sindicales, etcétera ${ }^{18}$ y la ruptura del pacto social subyacente al constitucionalismo democrático-social con Estado Social de Derecho (al que se intenta convertir en un "Estado de mercado"), necesita ser gobernó y reorientado en una sociedad civilizada. Y ello por contraposición a los enfoques ideológicos deterministas que entienden que la globalización y la nueva revolución tecnológica suponen una inevitable descomposición de la sociedad del trabajo democráticamente organizada, desconociendo que esos cambios están asociados a las políticas neoliberales que han fomentado un determinado modelo de globalización liberalizadora y una orientación política y cultural (hegemonía) que convierte en inevitable los que corresponde al espacio de decisión de la Política y el Derecho. Un enfoque determinista neoliberal que ha permitido justificar la redistribución de la renta del trabajo al capital, el aumento de las desigualdades sociales, y la reducción y neutralización del garantismo jurídico de los derechos sociales fundamentales (una remercantilización de los derechos laborales y de las fórmulas de protección social pública) ${ }^{19}$. Ciertamente la presente coyuntura se caracteriza por las innovaciones tecnológicas y su aplicación a los procesos productivos, y ello supone que tanto transformación como destrucción o creación de nuevos empleos. Los enfoques apriorísticos sobre sus resultados no simples augurios sin fundamento científico sólido. Por lo demás, siempre habrá un espacio para la decisión política -de política del Derecho-

\footnotetext{
${ }^{15}$ Hobsbawm, E. J.y Rudé, G.: Revolución industrial y revuelta agraria. El capitán Swing, Madrid, Siglo veintiuno de España editores, 1969 ( $2^{\mathrm{a}}$ ed. 2009); Jones, Steven E.: Against technology: from the Luddites to Neo-Luddism. CRC Press, 2006; Sale, K.: Rebels against the future: the Luddites and their war on the Industrial Revolution: lessons for the computer age, Basic Books, 1996.

${ }^{16}$ CASTELLS, M.: La era de la información: economía, sociedad y cultura, 3 Vols., Madrid, 1996-2003. ${ }^{17}$ PIKETTY, TH: Le Capital au XXI siècle, París, Editions du Seuil, 2013 (publicado por la Editorial Fondo de Cultura Económica en español, 2016; y por RBA, 2015).

${ }^{18}$ Puede consultarse OIT: La relación de trabajo: una visión comparativa, Resumen Ejecutivo, bajo la dirección de G. Casale, Ginebra, Oficina Internacional del Trabajo, 2011.

${ }^{19}$ Puede consultarse MONEREO PÉREZ, J.L.: La metamorfosis del Derecho del Trabajo, Albacete, ed. Bomarzo, 2017, págs. 9 y sigs.
} 
en favor del trabajo decente y de un renovado sistema de protecciones sociales suficientes y adecuadas socialmente para atender a las nuevas situaciones de necesidad de los individuos.

Desde esa perspectiva hegemónica se construye un discurso donde los modelos garantistas de Derecho del Trabajo y de la Seguridad Social estarían no sólo desfasados, sino presididos por una heterogonía de sus fines típicos, pues se afirma que son disfuncionales ellos mismos para garantizar el empleo y las protecciones sociales que exige la actual Era digital. En ese discurso no hay lugar para el pleno empleo de calidad, que estamos ante el "fin del trabajo" (desde hace tiempo afirmado y ahora revitalizado con la expansión de la cuarta revolución industrial), que no es posible mantener (por ser financieramente insostenibles) los pilares del Estado Social (como el sistema de Seguridad Social y las demás formas de protección social pública). Con este discurso no hay espacio de decisión para la política democrática para gobernar el destino de las sociedades y sólo cabría dejar a las fuerzas operantes en el mercado con apoyo estatal de fomento las grandes "decisiones" sobre la orientación de la economía y la realización de la cohesión social. Precisamente, frente a ello, la lógica del Estado Social ha sido -y esla del gobierno de la economía y de los procesos sociales al servicio de la sociedad en su conjunto.

Es esa lógica de integrar el desarrollo económico y el progreso social lo que preside las respuestas actuales de defensa del Estado Social y Democrático de Derecho.

Paradigmáticamente, habría que recordar aquí el Informe de la OIT, "El empleo atípico en el mundo. Retos y perspectivas", noviembre de $2016^{20}$; la Recomendación OIT, núm. 205 (2017), sobre el empleo y el trabajo decente para la paz y la resilencia, que precisamente subraya la orientación de las políticas hacia el pleno empleo de calidad y la protección social (recogiendo la garantía de "la seguridad básica del ingreso") ${ }^{21}$. En la

\footnotetext{
${ }^{20}$ En dicho informe se propone un conjunto de políticas para abordar los déficits de trabajo decente en el empleo atípico y en general precario, concluyendo que es preciso que se realicen políticas que garanticen que todas las modalidades de empleo sin excepción constituyan trabajo decente, pues ninguna forma contractual es inmune a las continuas transformaciones del mundo del trabajo. Si bien es indudable que el futuro traerá nuevos cambios, nuestro sustento seguirá dependiente del trabajo y sus efectos en el bienestar general de las personas no cambiarán. Así pues, corresponde a los gobiernos, a los empleadores, a los trabajadores y a sus organizaciones, mediante esfuerzos nacionales, regionales e internacionales, abordar estos desafíos en el contexto de los debates sobre el futuro del trabajo con el objetivo de promover el trabajo decente para todos.

${ }^{21}$ Así, entre los principios rectores: Al adoptar medidas relativas al empleo y al trabajo decente para responder a las situaciones de crisis provocadas por los conflictos y los desastres y con miras a la prevención, los Miembros deberían tener en cuenta lo siguiente: a) la promoción del empleo pleno, productivo y libremente elegido y el trabajo decente, que son factores decisivos para promover la paz, prevenir las crisis, posibilitar la recuperación y potenciar la resiliencia; b) la necesidad de respetar, promover y hacer realidad los principios y derechos fundamentales en el trabajo, otros derechos humanos y otras normas internacionales del trabajo pertinentes, $y$ tener en cuenta otros instrumentos y documentos internacionales, según proceda y sea aplicable; c) la importancia de la buena gobernanza y la lucha contra la corrupción y el clientelismo; d) la necesidad de respetar las leyes y políticas nacionales y utilizar los conocimientos, las capacidades y los recursos locales; e) la naturaleza de la crisis y la magnitud de su impacto en la capacidad de los gobiernos, incluidos los gobiernos regionales y locales, las organizaciones de empleadores y de trabajadores y otras instituciones nacionales e instituciones pertinentes para aportar
} 
larga duración, lo que preside la acción de la OIT es una lucha por la justicia social y sus garantías jurídicas e institucionales ${ }^{22}$.

En estas coordenadas de política del Derecho Social la OIT apuesta la celebración de un nuevo contrato social para el futura del trabajo decente, que afronte la desigualdad, la

respuestas eficaces, con la cooperación y asistencia internacionales necesarias, según se requiera; f) la necesidad de combatir la discriminación, los prejuicios y el odio por motivos de raza, color, sexo, religión, opinión política, ascendencia nacional, origen social, discapacidad, edad, orientación sexual o de otra índole; g) la necesidad de respetar, promover y hacer realidad la igualdad de oportunidades y de trato entre mujeres y hombres, sin discriminación de ningún tipo; h) la necesidad de prestar una atención especial a los grupos de población y a las personas a los que la crisis ha hecho particularmente vulnerables, incluyendo, aunque no únicamente, a los niños y niñas, las personas jóvenes, las personas pertenecientes a minorías, los pueblos indígenas y tribales, las personas con discapacidad, los desplazados internos, los migrantes, los refugiados y otras personas desplazadas por la fuerza a través de las fronteras; i) la importancia de identificar y evaluar toda consecuencia negativa y no intencionada y de evitar los efectos colaterales perjudiciales para las personas, las comunidades, el medio ambiente y la economía; j) la necesidad de una transición justa hacia una economía ambientalmente sostenible como medio para el crecimiento económico sostenible y el progreso social; k) la importancia del diálogo social; 1) la importancia de la reconciliación nacional, cuando proceda; $\mathrm{m}$ ) la necesidad de solidaridad, responsabilidad y carga compartidas y cooperación a nivel internacional, de conformidad con el derecho internacional, y n) la necesidad de una estrecha coordinación y de sinergias entre la asistencia humanitaria y la asistencia para el desarrollo, en particular con miras a la promoción del empleo pleno, productivo y libremente elegido y el trabajo decente y de oportunidades de generación de ingresos, evitando la duplicación de esfuerzos y de mandatos. Y respecto a la Protección Social: En sus respuestas a las situaciones de crisis, los Miembros deberían, tan pronto como sea posible: a) tratar de garantizar la seguridad básica del ingreso, en particular para las personas que hayan perdido sus puestos de trabajo o medios de vida a causa de la crisis; b) adoptar, restablecer o ampliar regímenes integrales de seguridad social y otros mecanismos de protección social, teniendo en cuenta la legislación nacional y los acuerdos internacionales, y c) tratar de garantizar el acceso efectivo a una atención de salud esencial y a otros servicios sociales básicos, en particular para los grupos de población y las personas a los que la crisis ha hecho particularmente vulnerables. $22 \mathrm{~A}$ fin de prevenir las crisis, posibilitar la recuperación y potenciar la resiliencia, los Miembros deberían establecer, restablecer o mantener pisos de protección social y procurar cerrar las brechas de cobertura, teniendo en cuenta el Convenio sobre la seguridad social (norma mínima), 1952 (núm. 102), la Recomendación sobre los pisos de protección social, 2012 (núm. 202), y otras normas internacionales del trabajo pertinentes.

${ }^{22}$ RODGERS, G. et altri.: La OIT y la lucha por la justicia social, 1919-2009, Ginebra, Oficina Internacional del Trabajo, 2009. Y sólo ejemplificativamente, OIT: Marco multilateral de la OIT para las migraciones laborales. Principios y directrices no vinculantes para un enfoque de las migraciones laborales basado en los derechos, Ginebra, Oficina Internacional del Trabajo, 2007; OIT: La igualdad de género de género como eje del trabajo decente, Informe IV, Conferencia Internacional del Trabajo, $98^{\mathrm{a}}$ reunión, Ginebra, Oficina Internacional del Trabajo 2009; OIT: "Declaración de la OIT sobre la justicia social para una globalización equitativa, adaptada por la conferencia Internacional del trabajo en su nonagésima séptima reunión, Ginebra, Oficina Internacional del Trabajo, 10 de junio de 2008; OIT: Declaración de la OIT relativa a los principios y derechos fundamentales en el trabajo, adoptada por la Conferencia Internacional del trabajo en su octogésima sexta reunión, Ginebra, Oficina Internacional del Trabajo 18 de junio de 1998 (Anexo revisado, el 15 de junio de 2010), 2a ed., revisada, 2010. Puede consultarse, MONEREO PÉREZ, J.L.: "Refundar el ordenamiento laboral para juridificar plenamente el principio de justicia social y el trabajo decente", en Lex Social. Revista jurídica de los derechos sociales, Vol. 9, núm. 1 (2019), págs. 220-294; Ibid., "Los derechos sociales fundamentales ante las recientes reformas: un desafío para el trabajo decente”, y VEGA RUIZ, M.L.: "El futuro del trabajo: ¿Regular un derecho humanos? El debate sobre la centralidad del ser en el trabajo", en VVAA.: El futuro del derecho del trabajo y de la seguridad social en un panorama de reformas estructurales: Desafios para el trabajo decente, Congreso Internacional de Granada, Monereo Pérez, J.L., Túlio Barroso, F., Las Heras, H. (Dirs.), Moreno Vida, M.N. y Maldonado Molina, J.A. (Coords.), Murcia, Ed. Laborum, 2018, págs. 27-84, y págs. 11-26, respectivamente.; VV.AA.: El trabajo decente, Monereo Pérez, J.L., Gorelli Hernández, J. y, De Val Tena, L.A. (Dirs.), López Insua, B.M. (Coord.), Granada, Ed. Comares, 2018. 
seguridad de los ingresos y unas relaciones laborales presididas por el diálogo social y la regulación legal y convencional ${ }^{23}$.

Y como se verá más adelante y resulta visible, las instancias de la Unión Europea debaten, en esta coyuntura epocal, sobre la necesidad de instaurar una renta mínima europea. Resulta particularmente expresivo el Dictamen del Comité Económico y Social Europeo sobre la renta mínima europea e indicadores de pobreza (Dictamen de iniciativa) ${ }^{24}$. Su partido de partida es que la falta de reformas estructurales ante la crisis y las transformaciones en curso exige con carácter urgente adoptar un modelo político capaz de reforzar la solidaridad y los valores fundamentales del acervo social europeo. En la difícil coyuntura actual, "el establecimiento de una renta mínima europea contribuirá a la cohesión económica, social y territorial, a la protección de los derechos fundamentales, al equilibrio entre los objetivos económicos y sociales y al reparto equitativo de los recursos y la renta".

Pero es de realzar que lo que propone el CESE, después de un debate en profundidad sobre esta cuestión es "la acuciante necesidad de garantizar una renta mínima adecuada en la Unión Europea mediante una Directiva Marco" dirigida a combatir la exclusión social y la pobreza. En cuanto a la financiación, sugiere a la Comisión que estudie las posibilidades de financiación de dicha renta mínima garantizada europea prestando especial atención a la perspectiva de establecer un "fondo europeo adecuado". No es baladí hacer notar que la renta mínima no se concibe como una alternativa sustitutoria del pleno empleo, pues se "subraya que tener un empleo digno es la mejor garantía contra la pobreza y la exclusión social”. Para el CESE la renta mínima garantiza es un ingreso que no está basada en el pago de cotizaciones y que proporciona una red de seguridad para las personas que no pueden optar a las prestaciones de la Seguridad Social ${ }^{25}$. Su fundamento residiría especialmente en el art. 10, párrafo 2 de la Carta Comunitaria de los derechos sociales fundamentales de los trabajadores (1989) y en art. 34, párrafo 3 de la Carta de los Derechos Fundamentales de la Unión Europea (2000/2007).

EL CES subraya el potencial estabilizador de los regímenes de renta mínima, que podrían mitigar el impacto social de la crisis y provocar un efecto anticíclico, proporcionando recursos adicionales para impulsar la demanda en el mercado interior. Pero es de realzar que a pesar de los resultados positivos del método abierto de coordinación en el ámbito social, esta medida resulta insuficiente y hay que caminar en una dirección adicional que explore plenamente los instrumentos normativos y estructuras existentes para garantizar una mayor eficacia en las políticas de lucha contra la exclusión social y la pobreza en el

\footnotetext{
${ }^{23}$ OIT: La iniciativa del centenario relativa al futuro del trabajo. 4 Nota Informativa, Ginebra, OIT, 2019, págs. 1-9.

${ }^{24}$ (2014/C 170/04), Bruselas, Sesión de 10 de diciembre de 2013.

${ }^{25}$ Para el CESE hay que distinguir esta figura de otras políticas diversas como son: a) una renta básica universal o renta de integración, que es una ayuda permanente, de cuantía fija, que se paga intervalos preestablecidos a cada ciudadano adulto, independientemente de su situación económica o social o de su disponibilidad para el trabajo; y b) un impuesto negativo sobre la renta, basado en el concepto de tipo impositivo marginal.
} 
espacio jurídico europeo. De ahí que: "Para completar el método abierto de coordinación en materia de política social, el CESE apoya la introducción de una Directiva europea que amplíe los regímenes de renta mínima a todos los Estados miembros, aumente la eficacia de los regímenes existentes tomando en cuenta los distintos contextos nacionales y envíe así un potente mensaje sobre el pilar social europeo". La propuesta de Directiva Marco Europea debería establecer asimismo normas e indicadores comunes, proporcionar métodos para realizar el seguimiento de su aplicación y permitir la participación de los interlocutores sociales, los beneficiarios y demás partes interesadas a la hora de establecer o revisar los regímenes nacionales de renta mínima. El CESE realza que los regímenes de renta mínima están directamente vinculados a los sistemas de protección y prestaciones sociales, pero ello no debe conducir necesariamente a una dependencia con respecto a estos. En tal sentido los regímenes de renta mínima deberían ir acompañados de políticas generales y disposiciones específicas con las políticas activas de empleo, destinadas a las personas sin empleo a reincorporarse en el mercado de trabajo, servicios de colocación, una gestión de las prestaciones y los programas relativos al mercado laboral, como la formación y la creación de empleo apoyadas por estrategias de activación adecuadas, para dar mayores oportunidades a las personas en busca de empleo. Con lo que se enfatiza la renta mínima garantizada forma parte de un conjunto integrado de políticas públicas (política económica, política de empleo, política de fomento del empleo, etcétera).

Por su parte el Parlamento Europeo ha apoyado esta iniciativa de introducir una renta mínima ${ }^{26}$.

Aparte de ello existen otras iniciativas importantes que emanan de la sociedad civil y en particular de los agentes sociales. Así, se ha constituido la "Red Mundial de Renta básica" ("Basic Income Earth Network; https:/basicincome.org/), la cual ha venido realizando diversos Congresos Mundiales sobre la Renta Básica (una expresión distinta a la renta mínima garantizada, como luego se indicará), en la dirección de configurarla como un Derecho Humanos de contenido social. También ha impulsado distintas experiencias piloto en curso. El trasfondo es la más amplia necesidad estructural de repensar el Estado del Bienestar en el siglo XXI. En tal sentido considera que la Renta Básica no debe suponer una excusa para desmantelar el Estado Social, sino añadir una cobertura más plena de los ingresos que garanticen una integración en la sociedad democrática; pero también como una exigencia del propio sistema democrático en tanto que se base no sólo en una democracia formal, sino también en una democracia sustancial, asentada en el empoderamiento de los ciudadanos para que puedan vivir dignamente e intervenir plenamente en la construcción permanente de la vida social.

\footnotetext{
${ }^{26}$ Resolución del Parlamento Europeo, de 20 de octubre de 2010, sobre el papel de la renta mínima en la lucha contra la pobreza y la promoción de una sociedad integrada en Europa (2010/2039/(INI)), DO C70E de 8.3.2012, págs. 8-18; Resolución del Parlamento Europeo, de 15 de noviembre de 2011, sobre la plataforma europea contra la pobreza y la exclusión social (2011/2052(INI)), DO C 153E de 31.5.2013, pp. $57-78$.
} 
En el Informe 01|2017 Políticas públicas para combatir la pobreza en España ${ }^{27}$, se subraya respecto a los ingresos mínimos garantizados que hace ya varias décadas que la Unión Europea viene abordando estudios y recomendaciones en relación con la implantación por parte de los Estados miembros de un sistema de protección social pública y renta mínima caracterizado por el reconocimiento de un derecho subjetivo basado en la dignidad de la persona. La Recomendación del Consejo 92/441/CEE, de 24 de junio de 1992, relativa a los criterios comunes relativos a recursos y prestaciones suficientes en los sistemas de protección social desarrollaba los principios y modalidades de aplicación de la garantía de un nivel de recursos económicos coherente con el respeto a la dignidad humana. En este contexto, la cuestión de la garantía de rentas se ha sido enfocada sobre la base de los criterios de superación del asistencialismo tradicional y la discrecionalidad administrativa de las prestaciones y servicios asistenciales típicos.

Con la iniciativa impulsada (una propuesta ciertamente modesta, pero en la dirección correcta) por las organizaciones sindicales más representativas se presentó una "Proposición de Ley sobre establecimiento de una prestación de ingreso mínimos en el ámbito de protección de la Seguridad Social” $(2016)^{28}$. Su premisa es la inadecuación de nuestro sistema de garantía de rentas frente a los conocidos efectos del aumento de la pobreza. En España, un número cada vez mayor de personas se encuentran en riesgo de pobreza o exclusión y la pobreza severa afecta a tres millones; todo ello en un contexto de fuerte incremento del número de hogares sin ingreso alguno, de aumento del número de parados de larga duración y de reducción de las tasas de cobertura en el sistema de desempleo, con una elevadísima tasa de pobreza infantil. La necesidad de reforzar el actual sistema de protección social y de aportar soluciones es absolutamente imprescindible. Más allá de las dificultades económicas por las que atraviesa la economía española, la protección de las personas con escasa o ninguna cobertura social pública es una exigencia social, cívica y democrática. Las reformas de la protección por desempleo, lejos de haberse adaptado al actual mercado de trabajo y de dar respuestas al constante aumento del desempleo, han dado como resultado una política de contención del gasto, reduciéndose sus índices de cobertura, precarizándose no sólo el mercado laboral sino también la prestación por desempleo, que no llega a ofrecer una cobertura adecuada ni respecto a la población a proteger ni respecto a la duración de la percepción. Con los actuales instrumentos de protección social no se alcanza a proteger a todas las personas que se encuentran en situación de necesidad. Mientras que las prestaciones por desempleo

\footnotetext{
${ }^{27}$ Dictamen del Comité Económico y Social Europeo sobre el tema «Principios para unos sistemas de prestaciones sociales eficaces y fiables» (Dictamen de iniciativa) (2016/C 013/08). Consúltese también, CESE: Dictamen sobre la Renta mínima europea e indicadores de pobreza, SOC/482, diciembre de 2013. En este Dictamen el CESE recomienda que el sistema de rentas mínimas sea acompañado de otras medidas de políticas activas dirigidas a favorecer la incorporación al mercado de trabajo de la población más vulnerable, además de asegurar su acceso a servicios públicos de calidad.

${ }^{28}$ Corresponde a los números de expediente 120/000035 de la X Legislatura y 120/000003 de la XL Legislatura). 120/000002. Presentada por don José Campos Trujillo y otros. BOCG. Congreso de los Diputados. XII Legislatura. 9 de septiembre de 2016, núm. 3-1. Resulta harto significativa la comparecencia del Secretario General de UGT en el Congreso de los Diputados, en el marco de la Comisión del Pacto de Toledo, en defensa de esta Iniciativa Legislativa Popular (ILP), sobre la implantación de un sistema de garantías mínimas de rentas de ámbito estatal.
} 
sólo protegen al 55,7\% de las trabajadoras y de los trabajadores desempleados y con un una cobertura de carácter temporal, en el ámbito de protección que se ofrece desde otras administraciones públicas que proporcionan las rentas mínimas de inserción, se refleja una tasa de cobertura en la totalidad del Estado que apenas supera la cifra del 5,48\%. Dentro del ámbito de la Seguridad Social, las prestaciones por hijo a cargo son manifiestamente insuficientes para aliviar mínimamente la pobreza infantil (Exposición de Motivos de la ILP).

La prestación de ingresos mínimos de ILP es configurada como una prestación de modalidad no contributiva del Sistema de Seguridad Social destinada a garantizar unos ingresos adecuados a las personas que, con disponibilidad para trabajar, carecen de empleo y de unos recursos económicos para sí y, en su caso, para los familiares a su cargo (art. 1). La prestación de ingresos mínimos se define como una prestación de derecho subjetivo enmarcada en el nivel no contributivo de la Seguridad Social. La financiación debe garantizarse vía impuestos, a través de los Presupuestos Generales del Estado, y debe responder a los criterios de eficiencia y suficiencia y además contribuir a lograr una mayor cohesión social y territorial. El límite de de rentas o ingreso toma en consideración la unidad económica familiar. Se entiende por unidad económica familiar la derivada de la convivencia de la persona beneficiaria con su cónyuge, pareja de hecho y ascendientes o descendientes en primer grado, sean o no igualmente beneficiarios (art. 2.3). El Congreso de los Diputados, el 2.2. 2017 admitir a trámite la Iniciativa Legislativa Popular (ILP) impulsada por los sindicatos UGT y CCOO -y que 700.000 personas apoyaron con su firma- para establecer en España una renta mínima garantizada (RMG). Pero contó la oposición del Partido Popular y de Ciudadanos. A favor de esta nueva prestación social destinada a las personas sin recursos se han pronunciado el PSOE, Podemos, ERC, PDCAT y otras formaciones minoritarias.

La Renta mínima figura en la Pilar Europeo de Derechos Sociales ${ }^{29}$ y en el art. 34 de la Carta de los Derechos Fundamentales de la Unión Europea (en adelante, CDFUE) ${ }^{30}$. Sin

\footnotetext{
${ }^{29}$ Comunicación de la Comisión al Parlamento Europeo, al Consejo y al Comité de las Regiones, Apertura de una consulta sobre un pilar europeo de derechos sociales, Estrasburgo, 8.3.2016 $\operatorname{COM}(2016) 127$ final, y como desarrollo de ese Pilar Europeo de Derechos Sociales (En adelante, PEDS), Propuesta de Recomendación del Consejo, relativa al acceso a la protección social para los trabajadores por cuenta ajena y los trabajadores por cuenta propia, Estrasburgo, 13.3.2018 COM(2018) 132 final 2018/0059 (NLE). Esta Comunicación se basa expresamente en la Recomendación OIT, núm. 202 (2012), sobre los pisos de protección social R202 - Social Protection Floors Recommendation, 2012 (No. 202). Un análisis de los aspectos de Seguridad Social y protección social pública de la Propuesta de Recomendación de 13.3.2018 COM(2018) 132 final, en MONEREO PÉREZ, J.L.: "Pilar Europeo de Derechos Sociales y sistemas de seguridad social", en Lex Social. Revista de Derechos Sociales, Vol. 8, Núm. 2 (2018), págs. 251-298.

${ }^{30}$ Para en estudio sobre su alcance comprensivo de la rentas mínimas, véase MONEREO PÉREZ, J.L.: "Seguridad Social y Ayuda Social (Artículo 34 de la Carta de la UE)", en VV.AA.: La Europa de los Derechos. Estudio sistemático de la Carta de los Derechos Fundamentales de la Unión Europea, Monereo Atienza, C. y MONEREO PÉREZ, J.L. (Dirs. y Coords.), Granada, Ed. Comares, 2012, págs. 893 y sigs.; y reforzando el análisis de la necesaria perspectiva de la garantía multinivel de los derechos fundamentales, véase MONEREO PÉREZ, J.L.y ORTEGA LOZANO, P.G.: "Derecho a protección contra la pobreza y la exclusión social (artículo 30 de la Carta Social Europea", en VV.AA.: La garantía multinivel de los derechos fundamentales en el Consejo de Europa. El Convenio Europeo de Derechos Humanos y la Carta
} 
embargo, en la Recomendación sobre el acceso de los trabajadores a la protección social no se incluyen expresamente entre las ramas de Seguridad Social las rentas mínimas garantizadas o rentas de inserción (Apartado 3 de la Recomendación del Consejo relativa a la protección social para los trabajadores por cuenta ajena y los trabajadores por cuenta propia; Estrasburgo, 13.3.2018 $\operatorname{COM(2018)~} 132$ final), donde pesa el acotamiento preferente de las prestaciones contributivas y no contributivas de los regímenes de Seguridad Social, con remisión a las ramas de protección social a que se hace referencia en el apartado 5 de la Recomendación tal como se definen de conformidad con el Reglamento (CE) nº 883/2004 del Parlamento Europeo y del Consejo, de coordinación comunitaria de las prestaciones de Seguridad Social; expresamente se indica así en el Apartado 7.e) de la Recomendación) ${ }^{31}$. Ahora bien: en el caso de que una legislación de un Estado miembro de la Unión incluya una renta mínima dentro del sistema de Seguridad Social (paradigmáticamente, como prestación no contributiva interna a dicho Sistema) si habrá que entender que se aplica el Reglamento 883/2004. En España esto acontece con las rentas activas de inserción (RAI) en el marco de la protección por desempleo del Sistema de Seguridad Social, pero no respecto a las rentas mínimas de inserción (RMI), Rentas de ingresos o Rentas de Solidaridad -o con otras variadas denominacionesestablecidas por las Comunidades Autónomas (CC.AA) al amparo de sus competencias específicas en materia de "Asistencia Social" (art. 149.1.20 CE).

Dentro del tercero de los capítulos del PEDS (dedicado a la protección e incluso social), se acomete una ambiciosa propuesta de rentas mínimas en el principio 14 al indicar que "toda persona que carezca de recursos suficientes tiene derecho a unas prestaciones de renta mínima adecuadas que garanticen una vida digna a lo largo de todas las etapas de la vida, así como el acceso a bienes y servicios de capacitación. Para las personas que pueden trabajar, las prestaciones de renta mínima deben combinarse con incentivos a la (re)integración en el mercado laboral". El siguiente paso sería estudiar el modo y los distintos modelos en que se están implantando estos regímenes de renta mínima en la Unión Europea, a los efectos de comprobar su eficacia en los hogares para satisfacer sus necesidades. Entre los desafíos actuales sobre estos sistemas se encuentra la inadecuación de la cuantía de las prestaciones -que no permite a los beneficiarios salir de la pobreza-, la escasa cobertura y la falta de aprovechamiento de esta ayuda social de renta mínima debido a lo complejo que resulta acceder a estas medidas.

En la última década se han introducido nuevos criterios de desarrollo de la llamada "renta mínima europea", dentro del marco de la Estrategia de Lisboa y su sucesora, la Estrategia Europa 2020, que persiguen que este sistema de garantía de rentas esté vínculo al principio de inclusión activa y, por consiguiente, constituya el desarrollo de una renta

Social Europea, Monereo Atienza, C. y Monereo Pérez, J.L. (Dirs. y Coords.), Granada, Ed. Comares, 2017, págs. 925 y sigs.

${ }^{31}$ Véase el art. 3.1 ("Campo de aplicación material"). "El presente reglamento se aplica a toda la legislación relativa a la rama de Seguridad Social relación con: [...]". Por otra parte, se establece que "Salvo disposición en contrario del anexo XI, el presente Reglamento se aplicará a los regímenes de Seguridad Social generales y especiales, contributivos y no contributivos, así como a los regímenes relativos a las obligaciones del empleador o del armador" (art.3.2). Cfr., no obstante, el art. 58 del Reglamento 883/2004. 
básica, de carácter universal, que sea suficiente pero a la vez compatible con la inserción en el mercado de trabajo ${ }^{32}$.

En el dictamen del Comité Económico y Social Europeo (CESE) sobre la renta mínima europea, se señala que la renta mínima garantizada es una ayuda a los ingresos que no está basada en el pago de cotizaciones sociales y que proporciona una última red de seguridad para las personas que no pueden optar a las prestaciones de la seguridad social. El Comité entiende que como última salvaguarda contra la pobreza, está indisolublemente unida al derecho a llevar una vida digna de las personas que no tienen otra forma de asegurar sus ingresos y al de las personas que están a su cargo.

La Comisión Europea y el Parlamento Europeo han impulsado el proyecto EMIN o Red Europea de Renta Mínima, cuyo objetivo es construir un consenso para tomar las medidas necesarias para la incorporación progresiva de sistemas de ingresos mínimos adecuados y accesibles para los ciudadanos de los países miembros de la Unión Europea. Hay que tener en cuenta que el Parlamento Europeo defiende la implantación de una renta mínima en todos los países de la UE (2017). Se materializa en la Resolución del Parlamento Europeo, de 24 de octubre de 2017, sobre las políticas encaminadas a garantizar la renta mínima como instrumento para lucha contra la pobreza (2016/2270 (INI) ${ }^{33}$. Hay que tomar en consideración los trabajos realizados por la Comisión de Empleo y Asuntos Sociales del Parlamento Europeo, los comités de Empleo y Protección Social del Consejo de la UE, y las contribuciones nada despreciables de redes como la Red Europea de Renta Mínima (EMIN, por sus siglas en inglés) ${ }^{34}$ y todos los estudios de la Red Europea de Lucha contra la Pobreza (EAPN, por sus siglas en inglés) ${ }^{35}$, a los que también se asocia la CES. Todo ello, sin olvidar la labor de la OIT y del Consejo de Europa.

Es pertinente recordar que esta Resolución del Parlamento carece de fuerza normativa vinculante, aunque es un instrumento jurídico de enorme valor desde la perspectiva de la política del Derecho Social de la Unión. Y lo hace con referencia expresa a las Cartas Sociales Europeas y los instrumentos jurídicos de la OIT $^{36}$. Así en relación a la necesidad de establecer "Regímenes de renta mínima", se puede destacar los siguientes aspectos:

\footnotetext{
${ }^{32}$ La Recomendación de la Comisión 2008/867/CE, sobre la inclusión activa de las personas excluidas del mercado de trabajo hace pivotar esta en torno a tres aspectos fundamentales: un apoyo a la renta adecuado, mercados de trabajo inclusivos y el acceso a servicios sociales de calidad.

${ }^{33}$ Última actualización de 24 de junio de 2018.

$34 \quad$ https://eminnetwork.files.wordpress.com/2017/11/2017-nov-emin-la-route-de-lue-vers-lerevenu-minimum-fr-pdf-novembre-17.pdf. $35 \quad$ https://www.eapn.eu/wp-content/uploads/Working-Paper-on-a-Framework-Directive-ENFINAL.pdf.

${ }^{36}$ En el Preámbulo de la Resolución del Parlamento se citan, entre otros muchos instrumentos de fundamentación de la misma los siguientes:

- el artículo 5, apartado 3, del Tratado de la Unión Europea y los artículos 4, 9, 14, 19, 151 y 153 del Tratado de Funcionamiento de la Unión Europea,

- la Declaración Universal de Derechos Humanos de 1948, ratificada de nuevo por la Conferencia sobre los derechos humanos de 1993, y en particular sus artículos 3, 23 y 25,

- la Carta de los Derechos Fundamentales de la Unión Europea, y en particular sus disposiciones relativas a los derechos sociales y, más concretamente, sus artículos 34, 35 y 36, en los que se declaran 
El Parlamento Europeo pide a todos los Estados miembros que introduzcan regímenes de renta mínima adecuados, acompañados de medidas para favorecer la reincorporación al mercado de trabajo de todas las personas capaces de trabajar y de programas de educación y formación adaptados a la situación personal y familiar del beneficiario, con el fin de ayudar a las familias con ingresos insuficientes y permitirles que tengan un nivel de vida digno; hace hincapié en que esta renta mínima debe ser la última red de protección social y consistir en un apoyo financiero adecuado complementario a un acceso garantizado a servicios de calidad y a políticas activas de empleo, como el medio más eficaz para luchar contra la pobreza y garantizar una existencia digna a todos aquellos que no disponen de recursos suficientes; destaca, a este respecto, que el derecho a las ayudas sociales es un derecho fundamental y que los regímenes de renta mínima adecuados permiten a las personas vivir dignamente, favorecen su plena participación en la sociedad y garantizan su independencia a lo largo del ciclo de vida; Es que en otros Apartados se deja constancia de que el fundamento último es la dignidad humana y su elevación al máximo rango dentro de un sistema multinivel de garantías de los derechos fundamentales. Así, lamenta que algunos Estados miembros no parezcan tener en cuenta la Recomendación 92/441/CEE del Consejo, que reconoce «el derecho fundamental de la persona a recursos y prestaciones suficientes para vivir conforme a la dignidad humana»; y hace notar que, si bien la mayor parte de los Estados miembros disponen de regímenes nacionales de renta mínima, varios de estos regímenes no ofrecen un apoyo a la renta adecuado a todas las personas necesitadas; pide a todos los Estados miembros que prevean la introducción de regímenes de renta mínima garantizada y, en su caso, su mejora para contribuir a prevenir la pobreza y favorecer la inclusión social.

Se trata de un derecho de estructura jurídica compleja que entraña posiciones activas y posiciones pasivas de deber u obligación tanto para el sujeto o los que integran la unidad familiar como para los propios poderes públicos.

El Parlamento Europeo realza la perspectiva de política de familias (esto es, medidas jurídicas e intervenciones de los poderes gubernativos y de las Administraciones Públicas

específicamente el derecho a una ayuda social y a una ayuda de vivienda, el derecho a un nivel elevado de protección de la salud y el derecho de acceso a los servicios de interés económico general,

- la Carta Social Europea, y en particular sus artículos 1, 4, 6, 12, 14, 17, 19, 30 y 31,

- los Convenios de la Organización Internacional del Trabajo (OIT) n. ${ }^{\circ} 29$ y 105 sobre la abolición del trabajo forzoso, $\mathrm{y} \mathrm{n}^{\circ}{ }^{\circ} 102$ sobre la seguridad social, así como su Recomendación n. ${ }^{\circ} 202$ sobre los pisos de protección social,

- el Programa de Trabajo Decente y el Pacto Mundial para el Empleo de la OIT, aprobados por consenso mundial en la Conferencia Internacional del Trabajo del 19 de junio de 2009,

- las Conclusiones del Consejo de Empleo, Política Social, Sanidad y Consumidores, de junio de 2013, sobre el tema «Hacia la inversión social para el crecimiento y la cohesión»,

- la Recomendación 92/441/CEE del Consejo, de 24 de junio de 1992, sobre los criterios comunes relativos a recursos y prestaciones suficientes en los sistemas de protección sociall (Recomendación sobre los ingresos mínimos),

- la Recomendación 92/442/CEE del Consejo, de 27 de julio de 1992, relativa a la convergencia de los objetivos y de las políticas de protección social

- la Recomendación de la Comisión 2013/112/EU, de 20 de febrero de 2013, titulada «Invertir en la infancia: romper el ciclo de las desventajas» 
para facilitar recursos a las personas con responsabilidades familiares para que puedan desempeñar las mismas en las mejores condiciones y permitan la integración e inclusión de sus integrantes en la sociedad) en la que se enmarca la Renta mínima: es fundamental, en relación con el debate sobre la renta mínima, la posición especial en que se encuentran las familias con hijos y las familias monoparentales y hasta qué punto resultan afectadas 37 . Hay que tener en cuenta que el enfoque "familiarista" (o "familista") ha tenido una gran importancia en la construcción tradicional del modelo de Estado del Bienestar (y no sólo mediterráneo) en el que los vínculos, la dependencia y la solidaridad familiar continúan siendo unos de los grandes pilares básicos sobre el que se sustentan las políticas sociales del Estado del Bienestar ${ }^{38}$. El enfoque "familista" ha coexistido con la acción directa del sistema de protecciones sociales públicas. Esto permite comprender y explicar que los cambios en las estructuras y relaciones familiares han tenido siempre una gran influencia en la conformación y evolución de los diversos Estados del Bienestar.

En cuanto a su materialización e instrumentación jurídica viene a coincidir con la posición expresada en el Dictamen del CESE sobre la necesidad de formalizarla, conformarla y garantizarla a través de una Directiva-Marco relativa a una renta mínima adoptada en el marco del Derecho Social de la UE. Así se indica -coincidiendo con el Dictamen del Comité Económico y Social Europeo- que sería pertinente promulgar una Directiva marco sobre una renta mínima adecuada en la Unión Europea, que establecería normas e indicadores comunes, proporcionaría métodos para el seguimiento de su aplicación y mejoraría el diálogo entre las partes interesadas, los Estados miembros y las

\footnotetext{
37 El Apartado 30 de la Resolución parlamentaria se sitúa en esa lógica "familiarista". Destaca la importancia de definir unos criterios de admisibilidad apropiados y adaptados a la realidad socioeconómica de los Estados miembros que deban reunirse para poder beneficiarse de un régimen de renta mínima adecuado; considera que entre esos criterios debe figurar no ser beneficiario de una prestación por desempleo o que, aun siendo beneficiario, esta sea insuficiente para evitar la pobreza y la exclusión social, y se debe tener presente el número de hijos y de otras personas a cargo; insiste, no obstante, en que estos criterios no deben poner trabas administrativas para acceder a los regímenes de renta mínima a las personas que ya se encuentran en una situación muy vulnerable (por ejemplo, no se debe exigir una dirección fija en el caso de las personas sin hogar); También el Apartado 37, en el que se insiste en la necesidad de que se tenga en cuenta el número de personas a cargo al establecer el importe de la renta mínima, en particular los niños o las personas con un elevado grado de dependencia, con el fin de romper el círculo vicioso de la pobreza, y en especial de la infantil; pide a la Comisión y a los Estados miembros que garanticen la rápida aplicación de la Recomendación de 2013 titulada «Invertir en la infancia: romper el ciclo de las desventajas»; opina, además, que la Comisión debería elaborar un informe anual sobre los progresos en la lucha contra la pobreza infantil y sobre la aplicación de la citada Recomendación con la ayuda de los indicadores que en ella se facilitan (Este enfoque también, en el Apartado 38).

38 MORENO DOMÍGUEZ, AL.: "El familiarismo cultural en los estados de bienestar del sur de Europa. Transformaciones de las relaciones entre lo público y lo privado", en Sistema: Revista de ciencias sociales, núm. 182 (2004), págs. 47-74. En este estudio se presenta cómo la cultura familiarista característica de los países europeos -sobre todo mediterráneos)- se ha engendrado en un modelo de Estado del Bienestar en el que las cuestiones familiares se han considerado pertenecientes al ámbito estrictamente privado. Esta forma de entender las relaciones entre lo público y lo privado ha dado lugar a un modelo de sociedad y de Estado basado en la solidaridad intergeneracional y en la dependencia familiar de la mujer, lo que en cierta forma ha supuesto -criticablemente- un impedimento en el proceso de extensión de los derechos de ciudadanía social en los Estados del Bienestar postindustriales del sur de Europa. Esta idea de base también en AÑON, J. y MIRAVET, P.: "Paradojas del familiarismo en el Estado del bienestar: mujeres y renta básica", en Cuadernos de Relaciones Laborales, vol.23, núm. 2 (2005), págs. 101-121.
} 
instituciones de la Unión; y en esa línea de pensamiento interpela a la Comisión y a los Estados miembros para que estudien métodos e instrumentos para garantizar una renta mínima adecuada en todos los Estados miembros.

En definitiva, el Parlamento Europeo, apuesta por la implantación generalizada en los Estados miembros de una Renta mínima garantizada por un fondo de cohesión de la Unión, y su materialización en las sistemas de protección social pública en todos los países que forman parte de la misma.

Con todo, cabe decir que en los Estados miembros, hic et nunc, existe un laberinto de mecanismos (a menudo superpuestos y desorganizados) encaminados a proporcionar unos ingresos mínimos de subsistencia a sus beneficiarios, la evolución de estos últimos y la intensidad de la protección que brindan. Máxime, cuando en un contexto de incremento de la desigualdad y de sensibilización generalizada respecto a la misma, está retomando el debate central en las últimas décadas sobre la implantación de una renta mínima universal de subsistencia concebida como derecho social de nuevo tipo.

Se aprecian síntomas de descomposición del modelo clásico de protección social pública $^{39}$. En este contexto, la finalidad de un modelo de protección social que siga siendo protagonista destacado del cambio social ha de apoyarse - en obligado respeto del compromiso constitucional dentro del sistema multinivel de garantía de los derechos sociales fundamentales- en la integración de los derechos sociales en el status de ciudadanía, como una forma de acción encaminada a modificar el marco de las desigualdades sociales, según la clásica aspiración emancipadora y promocional del Estado Social de Derecho -garantizada como mandato constitucional ex art.9.2 $\mathrm{CE}^{40}$-, parece inexcusable la revisión de los términos tradicionales con que se ha venido afrontando las RMI o fórmulas análogas.

Con todo, el derecho a percibir una prestación de renta mínima de inserción (de estructura jurídica compleja) se resuelve en una nueva forma útil de gestión de lo social, pretende combinar la tradicional técnica de ayuda económica (política pública pasiva de protección social) con la técnica activa de inserción, que lo es de integración y participación. Ello requeriría, para su adecuada para su práctica efectiva, basarse no sólo en el compromiso prestacional del poder público sino también, y aunque en diverso grado, en el compromiso personal del individuo de poner de sí todo lo conveniente para conseguir la integración que el poder público ha de propiciar. Los principios de solidaridad e igualdad social

\footnotetext{
${ }^{39}$ Ampliamente, MONEREO PÉREZ, J.L.: Derechos sociales de la ciudadanía y ordenamiento laboral, Granada, Ed. Consejo Económico y Social de España, 1996, Tercera Parte ("La crisis del Estado del Bienestar y la revisión de las políticas públicas"), págs. 183 y sigs.; MONEREO PÉREZ, J.L. y MOLINA NAVARRETE, C.: El derecho a la renta de inserción. Estudio de su régimen jurídico, Granada, Ed. Comares, 1999, págs. 25 y sigs.

${ }^{40}$ Sobre la significación de política del derecho de este precepto, puede consultarse, MONEREO PÉREZ, J.L.y MOLINA NAVARRETE, C.: "La cláusula transformadora: el principio de igualdad de oportunidades", en VV.AA.: Comentario a la Constitución Socio-Económica de España, Monereo Pérez, J.L., Molina Navarrete, C. y Moreno Vida, M.N.(Dirs. y Coords.), Granada, Ed. Comares, 2002, págs. 131 y sigs.
} 
exigen que el conjunto de los ciudadanos (ciudadanos y personas residentes de larga duración) compartan una responsabilidad que es de todos y ponga los medios necesarios para posibilitar un acceso igualitario a las oportunidades y al ejercicio de los derechos sociales. Con esa finalidad, las diversas legislaciones en materia, europeas, regionales y autonómicas, en mayor o menor medida, prevén para los sujetos titulares o destinatarios de este tipo nuevo de prestaciones sociales su necesaria participación en programas y acciones de inserción, a través de convenios de contenido negociado. Este compromiso representaría para el individuo-sujeto jurídico la obligada expresión de su derecho a tomar parte activa en la vida social, su inserción en el sistema y no su dependencia del mismo. Igualmente, pone de manifiesto la necesidad que la sociedad tiene de su participación, garantizando de esta manera la igualdad de las partes intervinientes, según un imperativo inexcusable de la propia idea de ciudadanía social. Por ello, se entiende el derecho a la inserción como un derecho social que implica una combinación entre "derecho social" y "obligación jurídica", o en otros términos, un derecho social que incorpora la obligación jurídica instrumental (de los sujetos titulares y de los poderes públicos concernidos o intervinientes) al estatuto social, a diferencia del "derecho al trabajo" que incorpora el status al contrato de trabajo.

Ante la nueva Era Digital el Consejo Económico y Social Europeo (CESE), aprobó un nuevo Dictamen precisamente sobre "Seguridad Social sostenible y sistemas de protección social en la Era Digital" (Dictamen de iniciativa) ${ }^{41}$. En un contexto marcado por la incertidumbre se observa que los sistemas de seguridad y de protección social deberán adaptarse y responder adecuadamente a las transformaciones que derivan de la digitalización en los mercados y en los ciclos de vida de las personas. Se trata de identificar de forma comunicativa y concertada las medidas necesarias para ello, con la finalidad de que el sistema de protección social continúe siendo viable y adecuado en el nuevo contexto de la digitalización. El dato a retener es que es posible que una parte creciente de los trabajadores no esté en condiciones de contribuir a los sistemas establecidos de Seguridad Social, por lo que no podrían estar cubiertos por ellos, en particular por lo que respecta a las prestaciones de jubilación, de desempleo y salud.

Ciertamente la digitalización (la Era digital) está ocasionando transformaciones relevantes en el mercado de trabajo con formas de contratación que no encajan -o encubren- dentro del marco de la relación tradicional de tipo empleador-trabajador (es el caso de los trabajadores de las plataformas que frecuentemente son considerados problemáticamente trabajadores autónomos o parasubordinados). Lo cual somete a los sistemas de Seguridad Social a una fuerte presión para abordar la organización de las técnicas de cobertura más pertinentes y adecuadas conforme a los principios y derechos sociales fundamentales de los sistemas nacionales en el trabajo y en la Seguridad Social. De no ser así muchas personas que trabajan precariamente o que pierden su empleo (sobre todo una edad madura o avanzada) pasarían a ser personas necesitas de protección pero

${ }^{41}$ SOC/560-EESC-2017-01220-00-00-AC-TRA (EN) 1/8, Decisión del Pleno 26/01/2017. Ponente: Petru Sorin Dandea. 
sin que ostenten el derecho correspondiente a ser atendidas por los sistemas de Seguridad Social vigentes pensados para una fenomenología del empleo (mediada por las nuevas tecnologías) distinta para las cuales se habían construido. El mundo del trabajo cambia y las protecciones sociales han de cambiar de manera simultánea y coherente gobernando los procesos sociales. Pero las protecciones sociales, en el mundo del trabajo y la economía, no tienen una mera incidencia defensiva o reactiva sino también una capacidad de gobernar y dirigir los procesos sociales. Hay que recordar que la economía de mercado, como otros y diferentes activos (colectivistas, mixtos, etc.), es "locus artificialis", y no "locus naturalis"; y que esta artificialidad se deriva de una técnica del Derecho que, en dependencia de las decisiones políticas, confiere "forma" a la economía -modelándola-, y la convierte, a menudo, en mercantil o colectivista o mixta, y en otras materializaciones o cristalizaciones. Que esas decisiones políticas son en sí mismas cambiantes. E así que los distintos regímenes de la economía están marcados por la "historicidad", y nadie puede llamarse absoluto y definitivo, pues están marcados por la contingencia permanente $^{42}$.

En particular, los regímenes públicos de jubilación de los Estados europeos se basan en el principio de solidaridad intergeneracional. Ahora bien, el importe de la pensión contributiva se calcula en función de las cotizaciones abonadas por el empleador y el trabajador durante el periodo de vida activa. Es así que los trabajadores que han ejercicio actividades atípicas o bajo las formas difusas facilitadas por el uso de las nuevas tecnología digitales - que no están formalizadas a través de un contrato de trabajo clásico, en muchos supuestos tendrán muchas dificultades para acumular derechos de pensión suficiente y adecuados atendiendo a estos períodos de cotización discontinuos y de baja cuantía. Al no tener un contrato laboral durante largos periodos de tiempo, la pensión de jubilación que percibirán será muy reducida (o incluso no tendrán una pensión contributiva, sino de carácter no contributiva). Es por ello por lo que se podrían encontrar por debajo del umbral de pobreza o de un nivel de vida digno en la fase de inactividad vinculada a la vejez.

Aparte de que las legislaciones nacionales sobre jubilación deberían establecer mecanismos para garantizar pensiones dignas, unas de las medidas que podrían paliar (no sustituir) esta situación de riesgo podría ser el establecimiento de normas mínimas Europeas en los regímenes nacionales de pensiones. Una de ellas podría ser la creación de mecanismos de garantías de ingresos como las rentas mínimas garantizadas de carácter no contributivo, lo cual podría ser especialmente útil para aquellos trabajadores con empleo atípico y aquellos que ejercen actividades de carácter profesional en el marco de los nuevos oficios propiciados por las tecnologías digitales. Esta medida se insertaría en un giro social de la Unión Europea en el sentido de crear una base europea de derechos sociales fundamentales. No se debe ser ingenuo al respecto, porque existen modelos de renta mínimas y de rentas básicas de inspiración neoliberal que postulan la sustitución -

\footnotetext{
${ }^{42}$ Véase IRTI, N.: L' ordine giuridico del mercato, Roma-Bari, Editori Laterza, $2^{\mathrm{a}}$ ed., 2004, Pág. V, y ampliamente, págs. 97 y sigs., y 111 y sigs.
} 
el desmantelamiento- de la mayoría de mecanismo de protección construidos por los Estados del Bienestar en la tradición del constitucionalismo democrático-social.

En CESE estima que dada la compleja situación en que se encuentran los trabajadores que ejercen nuevas formas de trabajo propias de la era digital se podría aportar una solución global a los problemas vinculados al reconocimiento de sus derechos en materia de seguridad y protección social procediendo a una reforma general del modelo de financiación del sistema (combinando cotizaciones e impuestos). Los Estados miembros han de buscar soluciones que permitan financiar los sistemas de Seguridad Social recurriendo a instrumentos que garanticen su sostenibilidad y respondan a la necesidad de ofrecer acceso a las personas que desempeñan su actividad según las nuevas formas de trabajo. E incluso considera que podría dedicarse una parte de los dividendos procedentes de la digitalización a garantizar la sostenibilidad de los sistemas sociales, también en el futuro, para perfeccionar los instrumentos de protección de las personas y "aliviar las cargas que pesan sobre el factor trabajo".

\section{3.-Identificación jurídica de las rentas de subsistencia .}

Ante el interrogante de cómo restablecer la condición de miembro de pleno derecho en la sociedad (que parte de la premisa de garantizar una existencia digna) caben distintas soluciones, que en parte han sido ya experimentadas, con mayor o menor intensidad (y con mayor o menor fortuna), en distintos países. Entre ellas nos encontramos con dos tipos ideales: las rentas mínimas de inserción o de integración (programa de ingresos clásicos condicionados); y renta básica o ingresó básico (programa de ingresos innovadoras incondicionadas). Estas figuras presentan puntos de conexión y diferencias específicas. Veámoslo brevemente.

En sus formas más evolucionadas las dos técnicas de protección enlazan con la conformación de un Estado del Bienestar Activo, comprometido con la participación de los individuos desde la libertad y la integración en todos los ámbitos de la vida social y económica. Una "forma-Estado" que impulsa el trabajo libremente elegido y de calidad, con derechos, en contraste con los Estados del Bienestar "pasivos" que se limitan a la dispensa de prestaciones, sin una apoyo eficaz a las políticas activas de empleo respetuosas con la libertad de elección y con el fomento de un empleo de calidad para las personas. A su manera, las RMI (como rentas activas de inserción) y la renta básica (como nivel básico de protección que permite la libre elección, acompañada de políticas públicas de fomento del empleo de calidad, independientes de la renta básica incondicionada). Ambos tipos de ingresos mínimos públicos son potencialmente (e incluso necesariamente) compatibles con políticas públicas de pleno empleo de calidad para todos los que estén en disposición de trabajar. Y, por tanto, tampoco resultan incompatibles con las políticas públicas que fomentan un empleo garantizado correspondiente al derecho al trabajo, es decir, la procura por parte del poder público de las condiciones de creación de 
empleo para todos y disfrutar dela oportunidad de hacer efectivo el derecho a un trabajo como compromiso por parte del Estado o poder público.

\subsection{La renta mínima de inserción como derecho subjetivo condicionado.}

Esta fórmula de protección social atiende a las situaciones de exclusión social vinculadas al trabajo. La medida se aleja de las tradicionales técnicas de ayuda asistencialista y vienen a reconocer un derecho social condicionado y subsidiario en relación a los demás instrumentos de protección social pública. Se formaliza en un convenio de inserción donde el sujeto asume obligaciones jurídicas establecidas en un programa de inserción profesional. Con ello se trataría de buscar una solución integral al problema de la exclusión social. Por tanto, está sujeto a comprobación de ingresos o recursos del individuo y de la familia o unidad de convivencia; y está sometido a obligaciones de los sujetos beneficiarios.

La experiencia ha tenido una especial relevancia en España a través de la iniciativa desplegada - muy fragmentada y falta de una mínima homogeneidad en los modelos de organización de los dispositivos y medidas establecidas- por las Comunidades Autónomas al amparo formal de sus competencias en materia de asistencia social (Art. 148.1.20 ${ }^{\text {a }} \mathrm{CE}$, relativo a la competencia de las Comunidades Autónomas en materia de "Asistencia social") y la inacción deliberada del Estado en esta materia (salvo la figura próxima, pero de distinta configuración técnica como la Renta Activa de Inserción, en el marco de la protección estatal por desempleo de la Seguridad Social ${ }^{43}$ ). Las CCAA han realizado una labor fundamental en la cobertura de este vacío de regulación estatal (tan sólo con la excepción puntual de la aludida renta activa de inserción en el marco de la protección legal por desempleo de la Seguridad Social). Esta técnica protectora no es una mera técnica de ayuda -va más allá de la lógica pasiva y estigmatizante de la asistencia social típica clásica-, pues configurada como derecho social combina, en una doble dimensión, el subsidio económico con las medidas de inserción laboral, las cuales son expresión de las políticas activas de empleo ${ }^{44}$. Con esta conceptualización general, las

\footnotetext{
${ }^{43} \mathrm{RD}$ 1369/2006, de 24 de noviembre, sucesivamente modificaciones y en algunos casos de carácter in peius a través del RD-Ley 20/2012, de 13 de julio, de medidas para garantizar la estabilidad presupuestaria $\mathrm{y}$ de fomento de la competitividad (señaladamente, se subordina el reconocimiento del derecho a la renta activa de inserción a la pérdida de un empleo previamente desarrollado, con lo que ello tiene de efecto expulsivo). Puede consultarse, SELMA PENALVA, A.: "La función social de la Renta Activa de Inserción en el Siglo XXI", en Revista de Derecho de la Seguridad Social Laborum, Número Monográfico: "Medidas de Seguridad Social de fomento del empleo y su incidencia en la sostenibilidad del sistema en España e Italia", 2014.

${ }^{44}$ Puede consultarse MONEREO PÉREZ, J.L, y MOLINA NAVARRETE, C.: El derecho a la renta de inserción. Estudio de su régimen jurídico, Granada, Ed. Comares, 1999; Ibid., "Un nuevo derecho social de ciudadanía: modelos normativos de rentas mínimas de inserción en España y en Europa”, en Revista de Trabajo y Seguridad Social. CEF, núm. 45 (1998); Ibid., La protección de los derechos fundamentales. El modelo europeo, Albacete, Ed. Bomarzo, 2009; VILA TIERNO, F.: "Política de inserción laboral (I. Rentas Mínimas de Inserción)", y GOERLICH PESET, J.M.: "Política de inserción laboral (II. Empresas de
} 
rentas mínimas de inserción o integración presentan los siguientes rasgos caracterizadores:

$1^{\text {a }}$. No tienen una proyección subjetiva universal, pues se someten a requisitos de ingresos o de recursos, no solo individuales sino familiares; y además suelen fijar un límite mínimo de edad para su percepción (lo que puede desproteger a los jóvenes excluidos del mercado de trabajo y sobrecarga a las familias con insuficiencias en el nivel de recursos). Si las RMI se entienden como rentas mínimas de existencia no parece coherente este tipo de exclusiones por razón de la edad. También se cuestiona el carácter universalista de acceso y disfrute debido a que suele exigirse la residencia legal, aunque este requisito puede quedar flexibilizado por la simple exigencia de empadronamiento de las personas migrantes en situación administrativa irregular ${ }^{45}$.

Pero, además, podría encontrar un reconocimiento como zócalo mínimo en una Directiva en el Derecho Social de la Unión Europea. Un sistema de transferencias sociales para la Unión podría asumir una función legitimadora y adherente a la intensificación del proceso de construcción de una Europa unida basada en la garantía de los derechos sociales y en la superación del déficit democrático (Reténgase referida Resolución del Parlamento Europeo sobre rentas mínimas). La RMI tiene la virtualidad de ir más allá de un ingreso reparador y de compensación, pues incorpora la garantía de un derecho a la reinserción laboral, como garantía del derecho al trabajo, que -eso sí- está condicionada por la suscripción de un compromiso que impone obligaciones al sujeto beneficiario pero también a los poderes públicos. Es por tanto, un convenio que entraña obligaciones jurídicas para bilaterales, sujeto beneficiario y poderes públicos actuantes.

$2^{a}$. Presentan una estructura jurídica e institucional compleja en diversas vertientes. En primer lugar, tienen carácter individualizado (que incluye itinerarios personalizados de inserción laboral) que se formaliza a través de un convenio de inserción en virtud del cual el sujeto beneficiario adquiere deberes de conduzca que condicionan la continuidad de las prestaciones (subsidios y servicios instrumentales que reciben, como, por ejemplo, formación profesional). En segundo lugar, el condicionante de un cierto nivel de recursos disponibles por el sujeto y la unidad familiar de pertenencia determina

\footnotetext{
Inserción)", ambos trabajos en VV.AA.: Las políticas Activas de Empleo: Configuración y Estudio de su regulación jurídica e institucional, Monereo Pérez, J.L., Fernández Berrnat, J.A., López Insua, B.M. (Dirs. y Coords.), Cizur Menor (Navarra), Ed. Thomson/Aranzadi, 2016, págs. 875 y sigs., y 895 y sigs., respectivamente. Para las políticas de activación garantista de la protección pública del empleo en la lógica del Estado del Bienestar "activo", puede consultarse, MONEREO PÉREZ, J.L.: "El sistema español de protección por desempleo: Eficacia, equidad y nuevos enfoques”, y LÓPEZ INSUA, B.M.: "La renta activa de inserción como instrumento de lucha contra la exclusión social", en VV. AA.: La Protección por desempleo en España. XII Congreso Nacional de la Asociación Española de Salud y Seguridad Social, Murcia, Ed. Laborum, 2015, págs. 125 y sigs., y 385 y sigs., respectivamente.

45 Véase VV.AA.: Comentario a la Ley y al Reglamento de Extranjería, Inmigración e Integración Social, Monereo Pérez, J.L., Ferández Avilés, J.A. y Triguero Martínez, L. (Dirs. y Coords.), Granada, Ed. Comares, 2012; VV.AA.: Refugiados y asilados ante el modelo social europeo y español. Estudio técnicojurídico y de política del derecho, Monereo Pérez, J.L. (Dir.), Triguero Martínez, L. (Coord.), Granada, Ed. Comares, 2017; MIÑARRO YANINI, M.: La dimensión social del Derecho de asilo. El estatuto de garantías de integración socio-laboral de los 'refugiados', Albacete, Ed. Bomarzo, 2018.
} 
un penetrante control administrativo de los recursos disponibles en cada momento -casi obsesivo - (ejercido en nuestro Estado Social Autonómico a través de las Comunidades Autónomas ${ }^{46}$ ). Vista desde las dos perspectivas (control de los compromisos asumidos; control de recursos obtenidos dinámicamente), la RMI comporta un fuerte control público social de los comportamientos del sujeto beneficiario de las medidas económicas y proactivas que se consagran en la RMI. Un control que es instrumental, pero que también presenta consecuencias negativas. La tecnología de los informes al respecto sobre las familias o unidades de convivencia, puesta a punto por el sistema público, puede convertirse fácilmente en una fórmula extensiva de control social, cuyas agentes están dirigidos por instancias enmarcadas en la red administrativa y disciplinaria del Estado o poder público.

$3^{\text {a }}$. Las RMI es sin duda un derecho social de desmercantilización (como son todos los derechos sociales a prestaciones positivas ${ }^{47}$, pero es un derecho que no tiene exclusivamente una dimensión individual, sino también "colectiva", pues normativamente está referido a la "unidad familiar" entendida de manera amplia y flexible (uniones de hecho, familia monoparental, unidad de convivencia o dependencia económica, etc.). El reconocimiento y cuantía se dirige a los hogares, se focaliza a la unidad familiar o de convivencia y no tanto individualmente. Este enfoque difumina y desdibuja la idea de una verdadero derecho subjetivo individual. Puede, así, que paradójicamente haya pocos incentivos para formar una unidad familiar o unidad de convivencia.

Se sitúa en la lógica propia del garantismo jurídico e institucional, que no se limita a proclamar los derechos como principios sino que trata de garantizarlos normativamente ${ }^{48}$, asumiendo la doble función de garantía de ingresos y de inserción laboral (y por tanto directamente vinculada a la realización del derecho al trabajo).

4a . La RMI es un derecho social condicionado, paradójicamente en lo que se supone su función o finalidad proactiva, porque, en efecto, el sujeto protegido ha de suscribir un convenio de inserción, en virtud del cual se asumen obligaciones jurídicas como contrapartidas condicionantes de "activación"-, cuyo incumplimiento puede determinar la suspensión o pérdida del subsidio económico. El incumplimiento de estas

\footnotetext{
${ }^{46}$ Puede consultarse, MONEREO PÉREZ, J.L. y DÍAZ-AZNARTE, T.: El Estado Social Autonómico, Albacete, Ed. Bomarzo, 2008, págs.44 y sigs.

${ }^{47}$ MONEREO PÉREZ, J.L.: Derechos sociales de la ciudadanía y ordenamiento laboral, Madrid, Ed. CES, 1996, págs. 45 y sigs.

${ }^{48}$ Para la distinción entre declaraciones y garantías, puede consultarse MONEREO PÉREZ, J.L.: "La Carta comunitaria de derechos sociales fundamentales de los trabajadores" (I) y (II), en Revista Española de Derecho del Trabajo. Civitas, núms. 56-57 (1992-1993), núm. 57 (1993), espec., págs. 85 y sigs.; Ibid., «Genealogía de las Declaraciones de Derechos y su significación político-jurídica», estudio preliminar a JELLINEK,G.: La declaración de los Derechos del Hombre y del ciudadano, Granada, Ed.Comares, 2009.Para el garantismo jurídico moderno y el modelo normativo de Derecho propio del Estado Social de Derecho, véase FERRAJOLI, L.: Derechos y garantías. La ley del más débil, trad. P. Andrés Ibañez y A. Greppi, Madrid, Ed. Trotta, 1999; Ibid., Principia iuris. Teoría del derecho y de la democracia. 1. Teoría del derecho, trad. J. C. Bayón, P. Andrés Ibañez, A. Ruiz Miguel, L. Prieto Sanchís, Madrid, Ed. Trotta, $2^{\text {a }}$ ed., 2016.
} 
obligaciones jurídicas determina, pues, un control sancionador que incide sobre el disfrute de las prestaciones económicas del sujeto titular, beneficiario o destinatario de la medida. Se trata de deberes públicos anudados al derecho social de prestación pública ${ }^{49}$. Sin embargo, cabe decir, críticamente, que se debería insistirse más en la denominada "activación objetiva" a cargo del poder público actuante para garantizar una empleabilidad positiva (en garantía de un verdadero derecho a la reinserción profesional), que sobre la llamada "activación subjetiva" que incumbiría exclusivamente al sujeto titular, beneficiario o destinatario de la medida de protección social.

En términos de conjunto, este instituto de protección social esta preordenado típicamente a la garantía de integración a través de la inserción laboral, en la lógica de entender el trabajo como el factor más relevante de integración y participación en la sociedad de pertenencia. La idea de fin del trabajo y del trabajo como un valor en extinción no se sostiene en la práctica, más bien se asiste a la emergencia constante de nuevas formas de trabajo $^{50}$. No está pensado como derecho social a la integración social fuera de la inserción en el mercado de trabajo. Y esta fuerte orientación "empleativa" muestra los límites de la medida de protección social en una sociedad en la que se acentúa la realidad del trabajo como bien escaso, y en la cual la precariedad laboral está deviniendo -por el momento- como un elemento estructural de modelo contratación y organización flexible del trabajo profesional, tanto por cuenta ajena como por cuenta propia (éste en expansión en sus diversas manifestaciones). La precariedad, la desestructuración del trabajo, las rotaciones laborales y la pérdida de los empleos están suponiendo una pérdida del control sobre su propia vida de los trabajadores ${ }^{51}$.

La fórmula de las RMI puede estar organizada a nivel nacional (renta mínima garantizada nacional) o a un nivel descentralizado (renta mínima garantizada a nivel regional, federal o de Comunidad Autónoma). Las RM de "primera generación" están dirigidas mayormente a las situaciones de pobreza y tratan de satisfacer necesidades vitales de las personas -o más exactamente familias- sin recursos. Este modelo de ingreso mínimo, evoluciona históricamente dando un salto cualitativo en distintos países hacia una RMI de "segunda generación", que trata de afrontar el problema devenido en estructural de la nueva pobreza y las situaciones de exclusión social (normalmente vinculadas a la falta de trabajo o a un trabajo precario que no libera de la pobreza). Se pretende luchar contra la pobreza y las situaciones de exclusión social en el marco de una estrategia que combina los subsidios con las medidas orientadas a la inserción profesional. Los subsidios pueden

\footnotetext{
${ }^{49}$ Puede consultarse, MONEREO PÉREZ, J.L., MOLINA NAVARRETE, C.: El derecho a la renta de inserción, cit., págs. 338 y sigs.

${ }^{50}$ RIFKIN, J.: El fin del trabajo. El declive de la fuerza del trabajo global y el nacimiento de la era posmercado, Barcelona, Ed. Paidós, 1996; MÉDA, D.: El Trabajo: Un valor en peligro de extinción, Barcelona, Ed. Gedisa, 1998.

${ }^{51}$ Paradigmáticamente, SENNETT, R.: La corrupción del carácter. Las consecuencias personales del trabajo en el nuevo capitalismo, Barcelona, Ed. Anagrama, 2000; REVILLI, M.: Más allá del siglo XX. La política, las ideologías y las asechanzas del trabajo, Barcelona, Ediciones de Intervención Cultural/El Viejo Topo, 2001.
} 
ser de diferente cuantía, previa comprobación de recursos, e incorporaran políticas activas de empleo encaminadas a la reinserción profesional ${ }^{52}$.

En España, la RMI o renta garantiza podría tener su encaje en el art. 41 de la Constitución, como un derecho dentro de un sistema evolucionado de Seguridad Social (Seguridad Social Asistencialista), es decir una prestación no contributiva de la Seguridad Social. Sin embargo, no ha habido voluntad política para implantarlo por esa vía. Ha sido obra de las Comunidades Autónomas la implantación en sus respectivos territorios de dispositivos de rentas o ingresos mínimos de inserción o de integración. Y lo han hecho al amparo de su competencia en materia de asistencia social (art. 148. 1.20 $\mathrm{CE}$ ). De este modo, se ha dado lugar a distintos modelos heterogéneos y con manifiestas desigualdades y deficiencias planteadas por gran parte de la doctrina. En un debate abierto, actualmente se postula una creación de una RMI en el ámbito estatal y en el marco del sistema de Seguridad Social utilizando el cauce competencial del art. 149.1.17 ${ }^{\mathrm{a}} \mathrm{CE}$. Y no sólo para garantizar la racionalización del sistema desvertebrado actual, sino también para garantizar el principio de igualdad y la mejora de la calidad de las prestaciones dispensadas (pues el modelo descentralizado por CCAA ofrece limitaciones e insuficiencias palpables para aborda de la raíz el problema de la cuestión social de la pobreza y la exclusión social) para lucha contra las situaciones de pobreza y de exclusión social.

\subsection{La renta básica garantizada o ingreso básico de ciudadanía como derecho subjetivo universal incondicionado.}

Muchas de las limitaciones que presenta la institución de la RMI (junto con las limitaciones e insuficiencias intrínsecas detectadas en los tradicionales sistemas existentes basados en las técnicas de ayuda social, como las prestaciones no contributivas y las prestaciones y servicios asistenciales) subyacen al nuevo impulso reformista social renovado hacia la instauración de una medida que tiene un amplio trasfondo histórico, como es la llamada renta básica (también denominado ingreso básico) ${ }^{53}$. Toda vez que comparte el objetivo general de garantizar una renta de subsistencia digna que cree las condiciones materiales para la integración y la participación social de las personas. Pero presenta de inicio la diferencia específica de que se configura como un derecho social estrictamente individual, incondicionado y de carácter universalista al proporcionar una renta a todos los ciudadanos y residentes de larga duración en el ámbito de una determinada comunidad o unidad política definida. Se afirma que superaría los límites de

\footnotetext{
52 Véase MONEREO PÉREZ, J.L., MOLINA NAVARRETE, C.: El derecho a la renta de inserción, cit.; GARCÍA ROMERO, B.: Rentas mínimas garantizadas en la Unión Europea, Madrid, CES, 1999.

${ }^{53}$ El trasfondo histórico es verificable en la propuesta de autores clásicos como Thomas Paine, Henry George, etcétera. Véase MONEREO PÉREZ, J.L.: "Pobreza, trabajo y exclusión social en la larga duración: una reflexión crítica a partir de Henry George", en revista Documentación Laboral, núm. 83 (2008), págs. 11-109; VAN PARIJS,PH. y VANDERBORGHT,Y.: Ingreso básico. Una propuesta radical para una sociedad libre y una economía sensata, trad. Laura Lecuona y Maia F. Miret, México, 2017, págs. 99 y sigs.; REY PÉREZ, J.L.: El derecho al trabajo y el ingreso básico ¿Cómo garantizar el derecho al trabajo?, Madrid, Ed. Dykinson, 2007, págs. 239 y sigs.; PISARELLO, G. y DE CABO, A. (eds.): La renta básica como nuevo derecho ciudadano, Madrid, Ed. Trotta, 2006.
} 
las medidas protectoras propias de las técnicas y programas tradicionales del Estado Social de Derecho, evitarían las trampas de la pobreza, la exclusión social y el desempleo, la estigmatización de las medidas asistenciales de ayuda, su carácter preventivo, el empoderamiento de la persona respecto a su posición en el mercado de trabajo, y asimismo su carácter redistributivo más conforme con la idea de justicia social.

Los rasgos caracterizadores de esta nueva forma de renta de subsistencia (al servicio del derecho a la existencia digna) muestran las diferencias específicas respecto a la medida de la RMI:

$1^{\circ}$. Su identificación. La renta básica o ingreso básico es un "ingreso pagado por el gobierno a cada miembro pleno de la sociedad a) incluso si no quiere trabajar, b) sin tener en cuenta si es rico o pobre, c) sin importar con quien vive y d) con independencia de la parte del país en la que viva" 54 . Esta definición deja constancia de la universalidad, su incondicionalidad y su carácter indiferenciado respecto a cualquier tipo de trabajo. Es un derecho social de integración, pero que tiene la virtualidad de que no se materializa necesariamente ni a través del fomento del trabajo ni del trabajo garantizado. Aunque, evidentemente, es compatible con la consecución de tales objetivos mediante otros instrumentos de intervención pública en las relaciones de mercado.

A través de ella se realizaría un principio de justicia social redistributiva y se trataría de hacer frente a la creciente desestructuración del trabajo, la precariedad y el amenazante riesgo de la exclusión social, de personas que van quedando en la periferia de la sociedad, en un proceso de discriminación negativa y de desafiliación social ${ }^{55}$. La renta básica sería un derecho social que se constituye en una condición necesaria para el ejercicio del conjunto de los derechos fundamentales de la persona. Garantizaría una seguridad económica frente a los riesgos y la inseguridad de la vida. Pero garantiza ante todo una libertad real para todos, pues empodera a las personas frente a los poderes insaciables del mercado y frente a los propios poderes políticos ${ }^{56}$. La renta básica puede tener la

${ }^{54}$ VAN PARIJS, PH.: Libertad real para todos, trad. Francisco Álvarez, Barcelona, Ed. Paidós, 1996, pág. 56.

${ }^{55}$ Véase, al respecto, CASTEL, R.: La discriminación negativa, trad. A. Martínez-Riu, Barcelona, Ed. Hacer, 2010; Ibid., El ascenso de las incertidumbres, Buenos Aires, FCE, 2010; MONEREO PÉREZ, J.L.: Los orígenes de la Seguridad Social en España. José Maluquer y Salvador, Granada, Ed. Comares, 2007; Ibid., "Los (pre)supuestos histórico-institucionales de la Seguridad Social en la constitución social del trabajo", VV.AA.: Orígenes del contrato de trabajo y nacimiento del Sistema de Protección Social, Rojas Rivero, Gl. (Coord.), Albacete, Ed. Bomarzo, 2012, págs. 203-328, espec., págs. 271 y sigs. [“La "tercera modernidad" o "postmodernidad" y la revisión del modelo de protección pública frente a los riesgos sociales. De la "sociedad aseguradora" a la "sociedad del riesgo". Las nuevas necesidades y técnicas emergentes. De la Seguridad Social "pasiva" a la "activa" (Estado Social Activo)], con referencia a las rentas mínimas. En particular, respecto a la justificación de la renta básica en la justicia social, véase STANDING, G.: La renta básica. Un derecho para todos y para siempre, Epílogo de Daniel Raventós y DavideCasassas, Barcelona, Ediciones de Pasado y Presente, 2018, págs. 29 y sigs.

${ }^{56}$ No es de extrañar que la defensa de la instauración de una renta básica por autores de distintas tradiciones de pensamiento. Para su fundamento desde una teoría de la justicia, véase VAN PARIJS, PH.: Libertad real para todos (qué puede justificar el capitalismo si hay algo que pueda hacerlo), trad. Francisco Álvarez, Barcelona, Ed. Paidós, 1996; FERRAJOLI, L.: La democracia a través de los derechos. El constitucionalismo garantista como modelo teórico y como proyecto político, trad. P. Andrés Ibañez, Madrid, Ed. Trotta, 2014, págs. 199 y sigs. 
virtualidad de política jurídica de actuar como contrapoder social en la dirección de una "ciudadanía de los poderes" (la renta básica incondicionada en relación al trabajo proporciona a los más débiles un poder de negociación superior al que ostentan a través de una simple renta garantizada condicionada al trabajo o a los recursos detentados) y no solo de los derechos garantizados desde el punto de vista jurídico-formal, sino precisamente con apoyo en los mismos. Y es que la "modernidad liberal restringida" llevó a cabo una concepción muy restrictiva de la ciudadanía, excluyendo durante largo tiempo de la ciudadanía real y efectiva a gran parte de la población de presente en la sociedad $^{57}$.

Actualmente existe una inseguridad crónica que se caracteriza principalmente por la incertidumbre que no puede ser afrontada a través de los mecanismos de anticipación propios de las situaciones de riesgo. La incertidumbre neutraliza la resiliencia, esto es, la capacidad del individuo de enfrentarse a, compensar y recuperarse de los shocks (eventos adversos no elegidos) y los azares (eventos habituales de la vida diaria que traen costes y riesgos, como el matrimonio, el nacimiento de un niño o la muerte). A diferencia de los riesgos que son previsibles y calculables (como lo hacen los programas típicos de Seguridad Social clásicos en las tradiciones de William Beveridge y Otto von Bismarck), la incertidumbre no puede serlo de igual manera. De ahí que la renta básica podría tener un efecto de seguridad frente a un entorno cada vez más caracterizado por la incertidumbre ${ }^{58}$. Enmarcada en el principio de justicia social la renta básica tendría un visible encaje en el Derecho Internacional de los Derechos Humanos, y ya desde la misma Declaración Universal de los Derechos Humanos de 1948, cuando en ella se afirma en su art. 25 que: "Toda persona tiene derecho a un nivel de vida adecuado que le asegure, así como a su familia, la salud y el bienestar...". Su materialización jurídico-positiva se realiza principalmente en el art. 11.1 del Pacto Internacional de Derechos Económicos, Sociales y Culturales (de 19 de diciembre de 1966), a cuyo tenor: "Todos los Estados Partes en el presente Pacto reconocen el derecho de toda persona a un nivel de vida adecuado para sí y su familia, incluso alimentación, vestido y vivienda adecuados, y a una mejora continua de las condiciones de existencia. Los Estados Partes tomarán medidas apropiadas para asegurar la efectividad de este derecho..." $"$.

\footnotetext{
${ }^{57}$ Para la complementaria e interdependencia de la "ciudadanía de los derechos" y la "ciudadanía de los poderes”, puede consultarse ampliamente, MONEREO PÉREZ, J.L.: Derechos sociales de la ciudadanía y ordenamiento laboral, Madrid, Ed. Consejo Económico y Social de España, 1996, espec., págs. 166 y sigs.

58 STANDING, G.: La renta básica. Un derecho para todos y para siempre, Epílogo de Daniel Raventós y Davide Casassas, Barcelona, Ediciones de Pasado y Presente, 2018, pág. 78; y para la distinción entre incertidumbre y riesgos sociales, BECK, U.: La sociedad del riesgo. Hacia una nueva modernidad, Barcelona, Ed. Paidos, 1998; LUHMAN, N.: Sociología del riesgo, México, Universidad Iberoamericana, $3^{\mathrm{a}}$ ed., 2006, espec., págs. 79 y sigs.

${ }^{59}$ AÑON ROIG, M.J.: "Derecho a un nivel de vida adecuado y medios de subsistencia", y MONEREO PÉREZ, J.L.: "Derecho a la Seguridad Social y Asistencia Social”, ambos en VV.AA.: El Sistema Universal de los Derechos Humanos, Monereo Atienza, C. y Monereo Pérez, J.L. (Dirs. y Coords.), Granada, Ed. Comares, 2014, págs. 543 y sigs. y 625 y sigs., respectivamente.
} 
Se parte, pues, de la idea de que los actuales sistemas de protección social del Estado del Bienestar son insuficientes para abordar esta nueva cuestión social planteada por la "sociedad del riesgo" ${ }^{\prime 60} \mathrm{y}$ la creciente incertidumbre que dificulta la prevención necesaria bajo el prisma tradicionalmente predispuesto por esta forma política específica y diferenciada de atender "lo social" (Basta reparar en el carácter condicionado de los programas y medidas de protección social actualmente existentes; la trampa de la pobreza y del desempleo que conduce a la exclusión social por el trabajo, los aspectos negativos en la perspectivas de género, los límites para realizar políticas preventivas de la situaciones de pobreza y exclusión social, el carácter estigmatizador de las ayudas, lo que suele afectar negativamente a la dignidad de la persona/familia o unidad de convivencia concernida, porque en el fondo son las familias en sentido amplio las que reciben las ayudas no contributiva o asistenciales). El problema es de adaptación del Estado Social de Derecho a un contexto profundamente cambiado en todos los ámbitos económicos, sociales, laborales, familiares y culturales. Por tanto, no se trata tanto de renunciar a las aportaciones institucionales civilizatorias de esta "forma Estado", sino de que se renueve en una dirección proactiva capaz de responder a los nuevos desafíos que plantea la protección e integración social de las personas. Si el modelo de sociedad va cambiando, el modelo de protección social ha de hacerlo también, pero no mecánicamente sino impulsando aquellas orientaciones que en cada momento son democráticamente formuladas por gozar del consenso en la sociedad. Esa renovación sí implicaría una racionalización del sistema heterogéneo y en gran medida caótico de las prestaciones no contributivas y asistencias dispensadas por el Estado central y las Comunidades Autónomas. Y la configuración que tenga esas medidas depende del modelo, los instrumentos y objetivos que se persigan. En la perspectiva del Estado Social de Derecho, que si prefigura un modelo de sociedad abierta pero sobre la base de la construcción irrenunciable a esta "forma Estado" de una democracia formal y sustancial (Estado material de Derecho que garantiza los derechos y libertades fundamentales para todos los miembros de la comunidad política): el objetivo es garantizar la dignidad humana, la igualdad social, la solidaridad social, la justicia social y la libertad real para todos. Es así que la renta básica estatal (y deseablemente apoyada en una renta básica europea) debería integrarse plenamente en el marco más amplio de las políticas públicas que materializan los fines emancipadores del Estado Social (paradigmáticamente, artículos 1, 10, apartados 1 y 2, 9.2 y 41 y siguientes de la Constitución Española). Precisamente por ello resulta necesario renovar el pacto social y en este sentido la renta básica contribuiría a ampliar ese contrato social que está en la base de los sistemas de protección social pública garantizando el derecho de subsistencia digna para todas las personas. De ello se sigue que habrá modelos de Renta Básica que no sean coherentes con los objetivos, principios e instrumentos propios de emancipación social del Estado Social de Derecho. Y desde esa perspectiva el jurista no puede ser neutral por imperativo constitucional, y tendrá que postularse por el rechazo de los modelos neoliberales de renta básica que supongan un Estado liberal residualista de mínimos y el desmantelamiento de las prestaciones de

${ }^{60}$ BECK, U.: La sociedad del riesgo. Hacia una nueva modernidad, Barcelona, Ed. Paidos, 1998. 
Seguridad Social Contributiva (por más que la instauración de una renta básica suponga necesariamente una racionalización y simplificación de los mecanismos de protección social no contributiva y de aquéllos de naturaleza estrictamente carácter asistencial, para evitar duplicidades y solapamientos y para hacer viable una protección efectiva para todos con un mínimo de homogeneidad prestacional que ha de ser garantizada por el Estado como instancia principal en la provisión de la protección de aquellas situaciones de necesidad social y políticamente más relevante y por ello mismo estatalmente "socializadas").

Se aduce igualmente que la garantía de la renta básica contribuiría a una mayor desmercantilización del trabajo humano e incrementaría una esfera autónoma que no podría reducirse al mercado ni a la decisión de los sucesivos gobiernos estatales ${ }^{61}$.

Su implantación (como, en el fondo, también lo es la posibilidad -aquí defendida- de instaurar un sistema estatal de rentas mínimas de inserción homogéneo para todo el Estado Social Autonómico) depende de una decisión esencialmente política, aunque condicionada económicamente por la garantía de su viabilidad en cada momento.

$2^{\circ}$. Carácter básico. Se trata de proporcionar una seguridad económica básica, capaz de hacer posible que el individuo pueda tener una vida digna, no de mera subsistencia vital. Pero no se trata de una seguridad total, ni, es obvio, de garantizar la abundancia de recursos, que en esos términos no sería ni factible ni deseable ${ }^{62}$. Tiene que ver con el principio de suficiencia para garantizar tanto la vida digna como una participación real, efectiva, en la sociedad o comunidad política de residencia o pertenencia. Lo cual implica que se recibiría un ingreso por encima del nivel mínimo de superación de la pobreza extrema y en el umbral histórico que sea económicamente sostenible (viable), sobre todo teniendo en cuenta que la renta básica debería estar, en principio, en condiciones de reemplazar a todas -a la inmensa mayoría- de las prestaciones públicas no contributiva y las estrictamente asistenciales.

$3^{\circ}$. La renta básica es una prestación en metálico y no en especie; es un ingreso en efectivo. Lo cual no excluye -desde luego- la dispensa de prestaciones complementarias de servicios. El ingreso en metálico confiere mayor libertad real a sujeto beneficiario. Como tal debería atenderse al principio de suficiencia que queda subyacente (casi explicitado) en el carácter "básico" de la medida, como referido no tanto a la cobertura de necesidades primarias del sujeto titular, sino como haciendo referencia a los mínimos necesarios en cada momento para garantizar una vida digna y autónoma de la persona.

$4^{\circ}$. Se trata de un ingreso que se materializa en pagos sucesivos o periódicos. No se trataría de un pago único que se entregara de una sola vez al sujeto protegido. Es decir,

\footnotetext{
${ }^{61}$ VAN PARIJS,PH. y VANDERBORGHT,Y.: Ingreso básico. Una propuesta radical para una sociedad libre y una economía sensata, trad. Laura Lecuona y Maia F. Miret, México, Libros Grano de Sal, 2017, pág. 170.

${ }^{62}$ STANDING, G.: La renta básica. Un derecho para todos y para siempre, Epílogo de Daniel Raventós y DavideCasassas, Barcelona, Ediciones de Pasado y Presente, 2018, pág. 13.
} 
se ingresa con una periodicidad regular (normalmente mensual, pero podría tener otros intervalos de regularidad).

$5^{\circ}$. Se trata de un derecho social individual que se paga al sujeto titular. En cuanto derecho estrictamente individual que se otorga en calidad de miembro de la comunidad política, el criterio de la familia o de la unidad familiar no cuenta en sí mismo para el reconocimiento y atribución de los ingresos correspondientes. Por tanto, se trata de un ingreso desvinculado de cualquier tipo de familia o unidad familiar. No atiende al estatuto familiar o de convivencia del individuo con otras personas. Tampoco atiende al estatus económico o financiero ostentado por la persona beneficiaria. La renta básica es un derecho social de ciudadanía que realiza los valores de la igualdad material y de la solidaridad. Su garantía como nuevo derecho social de integración representaría un giro la trayectoria renovadora del Estado Social de Derecho. Evidenciando la indivisibilidad de los derechos fundamentales, la renta básica es un instrumento de la libertad real, no meramente formal, y para todos, no sólo para una minoría. No se ingresa al cabeza de familia, como subsidio para todos los miembros, sino que se le abona individualmente a cada miembro adulto de la familia; y nótese que pudiendo contribuir entre todos al sostén de la familia o unidad de convivencia; afectando, así, a la distribución del poder dentro de la familia; en los programas de protección social ya existentes de RMI, la cantidad a la que un individuo tiene derecho depende de la composición de su hogar; no es así en la renta básica ${ }^{63}$.

$6^{\circ}$. La renta básica es abonada por un poder público. Lo que hace visible que se trata de un típico derecho social de desmercantilización que garantiza un nivel de vida, de bienestar, con independencia del poder contractual del individuo en el mercado. No se trata de un derecho "de clase", de "grupos" o de "categorías" de individuos en atención a su situación o posición en la estructura de la sociedad de pertenencia. El poder público puede ser un Estado nacional, centralizado o compuesto (Estado federal, de Comunidades Autónomas o de Regiones...); o en hipótesis supranacional, como sería su instauración factible en la Unión Europea (entendida como Unión Social Europea), como garantía de ingresos básicos ${ }^{64}$.

$7^{\circ}$. El carácter universalista de la renta básica hace referencia a que se reconoce a todos los miembros de la comunidad política de referencia, sean ciudadanos o residentes que acrediten un tiempo mínimo de permanencia y cualquiera que sea su condición de sexo, edad, situación social, etcétera. Con ello se transita del principio de selectivo y condicionado al principio universalista incondicionado. En cierta medida este rasgo llama también a su carácter tendencialmente uniforme para todos, y en necesario ajuste siempre revisable como condición necesaria para cumplir función jurídica e institucional. Como

\footnotetext{
${ }^{63}$ VAN PARIJS,PH. y VANDERBORGHT,Y.: Ingreso básico. Una propuesta radical para una sociedad libre y una economía sensata, trad. Laura Lecuona y Maia F. Miret, México, 2017, págs. 17 y sigs.

${ }^{64}$ Esta propuesta de una renta o ingreso básico en el marco político institucional de la Unión Europea ha sido realizada desde hace tiempo. Así, VAN PARIJS, P. y GENET, M.: "Eurogrant", Basic Income Research Group Bulletin, núm. 15 (1992), págs.4-7; Ibid., "Ingreso universal y pleno empleo. La alianza inevitable", en Papeles de la FIM, núm. 7 (1996), págs. 29-39.
} 
condición mínima, pues, a todo residente habitual de una comunidad política. Interesa destacar que no existe nada parecido a una redistribución a la inversa por el hecho de que las personas ricas o con más recursos la perciban, porque éstos deberán de abonar los correspondientes impuestos progresivos y por tanto con eficacia redistributiva. La renta o ingreso básico podría ser sostenible predisponiendo los impuestos que se requieren para financiarla ${ }^{65}$.

$8^{\circ}$. La incondicionalidad es una característica inherente a esta figura y uno de los aspectos que se apartan del tipo de transferencias de rentas que están previstas en el diseño tradicional de los Estados Sociales bajo la forma evolucionada de Estados del Bienestar. La renta básica no exigiría acreditar la carencia de recursos mínimos o suficientes para una vida digna (comprobación de recursos o de renta -previa o sobrevenida después de su concesión-que en el sistema de ayudas otorgadas por los sistemas clásicos de protección social están además vinculadas al conjunto de los recursos disponibles de la unidad familiar o unidad de convivencia, pues tienen una dimensión finalista "familiarista"; dimensión, ésta, que está ausente de la institución de la renta básica). La incondicionalidad comporta la no exigibilidad de obligaciones laborales $y$, en consecuencia, no depende de la disponibilidad de trabajar ni obligación de formarse "para" el trabajo. En este sentido no exige contrapartidas por parte del sujeto titular, beneficiario o destinatario. Es decir, no se exigirían condiciones de comportamiento o conducta del sujeto, como, por ejemplo, compromiso de actividad o de formación, puesta a disposición para trabajar, pues su pago está incondicionado respecto de toda obligación o deber de trabajar.

$9^{\circ}$. Tiene un carácter permanente como derecho social que garantiza un derecho a la existencia digna durante toda la vida de la persona, aunque siempre sometida de los principios de decisión en un sistema democrático.

$10^{\circ}$. La complementariedad de la renta básica con la percepción de pensiones contributivas, públicas o privadas, y con carácter subsidiario respecto de las prestaciones económicas contributivas de la Seguridad Social (por ejemplo, por incapacidad temporal y el subsidio de desempleo del nivel contributivo), porque no tienen un carácter sustitutivo respecto de estás que se otorgan en razón a determinadas circunstancias concurrentes específicas (situaciones de necesidad relevantes para el sistema público o para los sistemas privados, en su caso). Si tendría el efecto sustitutivo de las prestaciones no contributivas y asistenciales, basadas en la técnica de ayuda para garantizar precisamente una renta de subsistencia mínima del sujeto -y normalmente de su posible unidad familiar de inserción-. Ahora bien: su reconocimiento sí excluiría, por ejemplo, las prestaciones no contributivas por desempleo, por jubilación, por incapacidad permanente, por muerte y supervivencia. Pero no las prestaciones económicas por

\footnotetext{
65 VAN PARIJS,PH. y VANDERBORGHT,Y.: Ingreso básico. Una propuesta radical para una sociedad libre y una economía sensata, trad. Laura Lecuona y Maia F. Miret, México, Libros Grano de Sal, 2017, págs. 177 y sigs.
} 
dependencia que van más allá de la idea de subsistencia y atiende a la necesidad del cuidado de una tercera persona y técnicas especializadas.

En relación a esto, conviene señalar que la renta básica no exige el advenimiento de una contingencia determinante o situación de necesidad que haya que reparar mediantes un sistema de prestaciones que la exigen como premisa del supuesto de hecho. La renta básica por su propia lógica sólo se garantiza con base a la condición de miembro de la comunidad política (en un determinado espacio territorial y geopolítico), y por ello tiene un efecto preventivo ex ante(señaladamente, de la situaciones de pobreza y exclusión social frecuentemente atendidas desde sistema públicos de prestaciones no contributivas o asistenciales; pues evidentemente, los sistemas privados no resultan apropiados para atenderlas), el cual contrasta con la dimensión reparadora ex post de las prestaciones clásicas de los distintos instrumentos predispuestos en el marco en los Estados del Bienestar contemporáneos.

$11^{\circ}$. Carácter preventivo. Es necesario subrayar que la renta básica es un derecho social universalista que actúa preventivamente "ex ante", mientras que la RMI y otras técnicas de protección análogas basadas en la técnica de ayuda suelen actuar "ex posterior", esto es, cuando ya se ha producido la contingencia que hay que reparar. No obstante, evoluciona hacia la renta de solidaridad social asumen también -desde su propia peculiaridad- ese carácter preventivo, aunque de manera más incompleta.

\subsection{Del derecho a la renta mínima condicionada al derecho a la renta básica universalista e incondicionada: ¿Una transición posible?}

A partir de la implantación de una RMI multinivel en el ámbito de la Unión Europea (nivel nacional y nivel comunitario) podría caminarse a un planteamiento más utópico ciertamente-que evidentemente no significa inviable- de instaurar formas de transición hacia una renta básica sin desmantelar el Estado del Bienestar (incluidas todas las prestaciones contributivas, prestaciones de dependencia y servicios públicos de contenido social...). La renta básica supondría establecer un suelo o nivel básico de un nuevo sistema de distribución de los recursos, a partir de la cual se mantendrían los sistemas contributivos de protección social pública (señaladamente, las prestaciones de Seguridad Social contributiva). Su implantación permitiría subvenir a los déficits de cobertura que actualmente ofrecen los sistemas públicos de protección y Seguridad Social en un contexto de economías abiertas y flexibles y con una marcada tendencia estructural hacia la desestructuración y precarización laboral; y no puede garantizarse sin fisuras que pueda llevarse a cabo de manera generalizada políticas de pleno empleo de calidad o decente (estable, justamente remunerado, y con plenitud de derechos individuales y colectivos). En cualquier caso, ello no supondría renunciar a la realización del derecho al trabajo de todas las personas que lo deseen y estén en condiciones de trabajar, de manera que continuarían estando vigentes (y eficaces en términos jurídicos y también de eficacia social) las normas internacionales que garantizan el derecho al trabajo y su materialización a través de una política orientada al pleno empleo de calidad (trabajo 
decente o digno de la persona que trabaja ${ }^{66}$. La renta básica conferiría una precondición para autentificar y ejercer el derecho a trabajar libremente. Pero más aún: es una garantía de libertad para trabajar o no hacerlo, y ante todo para tomar decisiones con libertad sobre los asuntos que interesan a la vida política y social y a la trayectoria individual y convivencial (incluidas, la opción por formar una familia o por las diversas formas de unidades de convivencia).

La instauración de la renta básica, como nuevo pilar de un nuevo sistema de distribución de la renta, exigiría un largo proceso de transición y ante todo de experimentación ${ }^{67}$. Es difícil pensar en una implantación inmediata y generalizada erga omnes sino se realizar en el marco de una transformación del modelo de organización y gestión pública de "lo social"; y no parece nada fácil que se puedan instaurar sin más en un solo país de la Unión. En el caso de los países de la UE lo lógico sería su instauración a través de una intervención armonizadora de mínimos (y, por tanto, a nivel del ordenamiento jurídico comunitario), lo cual remite al instrumento normativo de la Directiva-Marco como mecanismo flexible de aproximación y convergencia en el espacio social europeo.

En el caso de España, al igual que ocurre en otros países europeos, habría que caminar hacia una decidida implantación de un sistema nacional de RMI, superando la heterogeneidad y aporías del modelo desvertebrado actualmente existente. Será después cuando, acaso, pueda pensarse en profundizar ese modelo nacional de RMI hacia la lenta experimentación de fórmulas análogas o próximas a la renta básica en sentido estricto, tal y como anteriormente se conceptualizado y delimitado anteriormente. Y ese largo camino a recorrer sólo evidenciando que las técnicas de ayudas proactivas ex post (RMI) son incapaces para afrontar el problema de la nueva cuestión social generada por la desestructuración del trabajo, la precariedad laboral, la tercerización de la economía, etcétera; circunstancias, éstas, que aconsejarían el establecimiento de medidas ex ante de carácter más preventivo (como sería el caso de la renta básica).

Para España se ha planteado una alternativa de financiación que implicaría un amplio proceso de redistribución de renta de los sectores más ricos o con más recursos al resto

\footnotetext{
66 Como lo consagran el art. 23 de la Declaración Universal de los Derechos Humanos: el Pacto Internacional de Derechos Económicos, Sociales y Culturales de 1966; o la OIT en su Convenio sobre la Política de Empleo, núm. 122 (1964), y en su Declaración para una globalización equitativa de 2008; pero también los instrumentos de Derecho Internacional Regional Europeo, como la Carta Social Europea Revisada de 1996; y la Carta de los Derechos Fundamentales de la Unión Europea (CDFUE); Véase MONEREO PÉREZ, J.L.: "Derecho al Trabajo (Artículo 1 de la Carta Social Europea)", y MONEREO PÉREZ, J.L.y LÓPEZ INSUA, B.M.: "Derecho a unas condiciones equitativas (artículo 2)", ambos en VV.AA.: La garantía multinivel de los derechos fundamentales en el Consejo de Europa. El Convenio Europeo de Derechos Humanos y la Carta Social Europea, Monereo Atienza, C. y Monereo Pérez, J.L. (Dirs. y Coords.), Granada, Ed. Comares, 2017, págs. 361 y sigs., y 395 y sigs., respectivamente; Ibid., "La garantía internacional del derecho a un "trabajo decente", en Nueva Revista Española de Derecho del Trabajo, núm. 177 (2015), págs. 27-72. Resulta de interés en este contexto, la llamada "Carta de los Derechos Humanos Emergentes", Institut de Drets Humans de Catalunya, Barcelona, 2004, elaborada por un grupo de expertos.

${ }^{67}$ VAN PARIJS,PH. y VANDERBORGHT,Y.: Ingreso básico. Una propuesta radical para una sociedad libre y una economía sensata, trad. Laura Lecuona y Maia F. Miret, México, 2017, págs.227 y sigs.
} 
de la población a través de la utilización instrumental de diversos tipos impositivos y de reformas que podrían suponer la supresión en distinta intensidad de prestaciones no contributivas o de carácter asistencial que sería innecesarias al instituir el sistema nacional de rentas básicas. De esta manera, en el largo camino hacia su implantación la renta básica se enmarcaría en una renovada política económica que permitirá garantizar la existencia material de toda la población, con lo que ello supone de realización de la justicia social pero también de nuevas razones para alcanzar una mayor legitimación política del sistema establecido que la instaure (incluida la UE, con el estigma persistente todavía de su déficit democrático). Son dos buenas razones para actuar ${ }^{68}$. Es decir una doble estrategia de incremento de los ingresos, por un lado, y de racionalización del sistema de prestaciones actualmente existentes en el cuadro del Estado del Bienestar ${ }^{69}$.

Con todo, la renta básica -como derecho de ciudadanía social- estaría orientada a garantizar una efectiva integración o inserción social ${ }^{70}$, atendiendo a razones democratizadoras, pero también a políticas de orden, pues el mundo será un lugar muchos más peligroso si no se logra la integración social. Debe, no obstante, hace referencia a los riesgos que la renta básica o asignación universal (que, como se ha dicho, consiste en el pago de un ingreso mínimo a todas las personas, atendiendo al vínculo de ciudadanía con independencia de toda contribución productiva y condicionalidad de ingresos) pueda tener, pues paradójicamente puede que permita eximir al mercado de toda obligación social, ya que si cada individuo goza de un mínimo de renta garantizada, es posible pensar que pueda aceptar -o verse obligado a ello- un empleo precario, que se situé en una situación de subempleo o en una situación salarial próxima a la pobreza relativa. La renta básica permitiría disociar el estatuto protector del estatuto jurídico del trabajo ${ }^{71}$. En cierto modo se estaría cerca del modelo de Estado Social "Paineano"72, que permitiría constituir un fondo para pagar incondicionalmente un ingreso uniforme a todos los miembros de la sociedad, el cual va más allá de la solidaridad tratando de poner en práctica el valor de la equidad. En esa lógica discursiva, la renta básica permitiría afrontar no sólo las situaciones de pobreza clásicas sino más precisamente el fenómeno de la exclusión social,

\footnotetext{
${ }^{68}$ En el sentido postulado por SEARLE. J.R.: Razones para actuar. Una teoría del libre albedrío, Oviedo, Ed. Nobel, 2000.

${ }^{69}$ Véase la propuesta de financiación elaborada en ARCARON, J., RAVENTÓS, D. y TORRENS, L.: Renta básica incondicional. Una propuesta de financiación racional y justa, Barcelona, Ediciones del Serbal, 2017; VAN PARIJS, PH.y VANDERBORGHT, Y.: La renta básica. Una medida eficaz para luchar contra la pobreza, trad. D. Casassas, Prólogo de D. Raventós, Barcelona, Ed. Paidós, 2006; VAN PARIJS,PH. y VANDERBORGHT,Y.: Ingreso básico. Una propuesta radical para una sociedad libre y una economía sensata, trad. Laura Lecuona y Maia F. Miret, México, 2017.

${ }^{70}$ Cfr. PARIJS,PH.v.y VANDERBORGHT,Y.: L' allocation universelle, París, Éditions La Découverte, París, 2005.

${ }^{71}$ Véase CASTEL,R.: L' Insécurité sociale. Qu' est-ce qu'étreprotégé?, París, Éditions du Seuil et La République des Idées, 2003, espec., cap. V.

${ }^{72}$ Modelo tributario de la memoria de Thomas Paine titulada La justicia agraria (1797), en El sentido común y otros escritos, est., prel., selección y trad., de R. Soriano y E.Bocardo, Madrid, Tecnos, 1990. En este sentido MONEREO PÉREZ, J.L.: "Pobreza, trabajo y exclusión social en la larga duración: una reflexión crítica a partir de Henry George", en Documentación laboral. Revista de relaciones laborales, economía y sociología del trabajo, y trabajo autónomo, núm. 83-Vol. II (2008), págs. 11-109, en particular 95-101.
} 
el cual incluye el carácter multidimensional de los mecanismos por los que las personas y grupos se encuentran excluidos de la participación de las prácticas propias de la participación activa en la vida social y política. La noción de exclusión social engloba las causas y los efectos de la nueva pobreza, consecuencia de los cambios estructurales de las economías y de las estructuras sociales contemporáneas.

Quizás la única manera de evitar este peligro de "heterogonía" de los fines ${ }^{73}$ de la medida de la renta básica sea buscar mecanismos adicionales y complementarios que prioricen las políticas de activas de pleno empleo garantizado por la intervención sistemática de los poderes públicos, quedando garantizado el derecho a la renta básica como medida complementaria y no sustitutiva de la obligación de los poderes públicos de garantizar las condiciones idóneas o apropiadas para que todas las personas que lo deseen tengan un empleo de calidad.

\section{4.-El modelo español desvertebrado de rentas mínimas de inserción o de renta garantizada de ciudadanía en el Estado Social Autonómico.}

En la evolución de la protección social en las dos últimas décadas sobresale positivamente la transición en muchos países desde los dispositivos asistenciales tradicionales hacia las rentas mínimas de inserción ${ }^{74}$. Esta transición supone un importante cambio conceptual de las rentas mínimas, pues se trata de figuras en las que convergen, a priori, dos derechos distintos, pero integrados en un "derecho función" de estructura compleja: el derecho al aseguramiento de un nivel mínimo de renta y el derecho a la provisión de itinerarios de inserción (diseño de proyectos individualizados, actividades formativas, trabajos de colaboración social, etc.). Ello dota a las rentas mínimas de inserción de un carácter diferente y alternativo a los sistemas tradicionales. Estos derechos, que descansan en lógicas contradictorias sólo en apariencia (reparadora y pro-activa), se conjugan así como manifestación del "derecho social a la inserción" pero -se insiste- como derecho de estructura y función jurídica compleja.

Es posible, pues, distinguir entre los ingresos mínimos de la "primera generación" y los de "segunda generación". El proceso de recreación -cuando no "reinvención"- de las RMI se ha acrecentado con la evolución hacia las "rentas de solidaridad activa", cuyo paradigma es nuevamente el ordenamiento francés. La "revenu minimum d' inserción"

\footnotetext{
${ }^{73} \mathrm{La}$ idea de heterogonía de los fines es una aportación lúcida de Max Weber. Véase, al respecto y en el marco de su pensamiento político y jurídico, MONEREO PÉREZ, J.L.: Modernidad y capitalismo. Max Weber y los dilemas de la teoría política y jurídica, Barcelona, Ediciones de Intervención Cultural/El Viejo Topo, 2013, y con un enfoque más particularizado, el ensayo de STARK, W.: "Max Weber y la heterogonía de los fines", en VV.AA.: Presencia de Max Weber, editado por Parsons, T. et altri, Buenos Aires, Ed. Nueva Visión, 1971, págs.191-208.

74 MONEREO PÉREZ, J.L.: "La renta de "subsistencia". En especial, la renta de inserción como derecho social", en VV.AA.: La jurisprudencia constitucional en materia laboral y social en el período 1999-2010. Libro homenaje a María Emilia Casas, Baylos Grau, A.P., Cabeza Pereiro, J., Cruz Villalón, J., Valdés Dal-Ré, F. (Coords.), Madrid, Ed. La Ley, 2015, págs. 713-755.
} 
(RMI), que aprobó por la Ley de 1 de diciembre de 1989, fue reemplazada por la "revenu de solidarité active" (RSA), creada por Ley n ${ }^{\circ}$ 2008/1249, de 1 de diciembre de 2008 generalizando la renta de solidaridad activa y reformando las políticas de inserción. A su vez, la RSA ha sido afectada -reemplazándola- por una nueva prestación denominada “prime d' activité", aprobada por la Ley de 17 de agosto de 2015. La RMI presentaba en el modelo francés también dos componentes: un componente de garantía de recursos y otro de inserción. A diferencia de la RMI la RSA y la "prima de actividad" jerarquizan expresamente las formas de inserción: hacen de la inserción profesional la forma prioritaria de inserción y presentan la inserción social como una inserción por defecto ${ }^{75}$. Acentúa, así, el elemento "pro-activo" profesional, pero dejando en un segundo lugar, en la prioridades o preferencias, el elemento de la reinserción social.

Todo ello en el sentido de que la función básica de los primeros es la de satisfacer las necesidades vitales de las personas consideradas, tratándose de prestaciones económicas con contraprestaciones ligeras por parte del beneficiario, tales como la aceptación de ofertas de empleo. Este tipo de rentas mínimas presenta algunos serios inconvenientes, bien porque no logran eliminar el estigma de la asistencia, bien porque se prefiere la ayuda material a las medidas de fomento de la inserción, con lo que se corre el riesgo de que los pobres queden en una situación de dependencia permanente del régimen de protección social (el conocido riesgo de la "cronificación"). Frente a estos sistemas, han surgido otro tipo de ingresos mínimos "de segunda generación”, en los que junto al riesgo de la pobreza, entendida como una insuficiencia de medios económicos, se contempla también el de la exclusión social y/o profesional. En este sentido, los ingresos mínimos se conciben como una estrategia de lucha contra la pobreza y la exclusión social en la perspectiva de la inserción, dado que se vincula el disfrute del subsidio con medidas complementarias de inserción social.

\footnotetext{
${ }^{75} \mathrm{Al}$ respecto, BADEL, M.: "La lutte contre les exclusions en droit français le rôle des minima sociaux. Rapport France”, en VV.AA.: La exclusión social: Estudio comparado desde la perspectiva jurídica laboral y constitucional, QUINTANILLA NAVARRO, R.Y. (Dir.), MATEOS Y DE CABO, Ó.I. (Coord.), Madrid, Universidad Rey Juan Carlos, 2018, págs. 317-337; y también, EYDOUX, A.: "Du RMI au RSA, la gouvernance de 1' insertion en questión", en Inform.soc., no 179 (2013); DAMON, J.: Le revenu universel en questions(s), en RDSS, 2016; Ibid., "L'investissement social: contenu et portée notion en vogue", en RDSS, 2015; LE NAIRE, O, et LEBON, C.: Le revenu de base, París, Éd. Actes Sud, 2017. Para ver esa evolución en la perspectiva comparada, MILANO, S.: "Le revenu mínimum garanti dans les pays de la CEE”, en Droit Sociale, 1988; MONEREO PÉREZ, J.L., y MOLINA NAVARRETE, C.: El Derecho a la renta de inserción, Granada, Ed. Comares, 1999; GARCÍA ROMERO, M.B.: Rentas mínimas garantizadas en la Unión Europea, Madrid, CES, 1999; KESSLER,F.: "Revenu minima en Europe: esquisse à d' evolutions légigislatives", en regards EN3S, n. 38 (2010). Una revisión del ingreso básico y "sus parientes" en perspectiva de síntesis, en VAN PARIJS, PH.y VANDERBORGHT, Y.: Ingreso básico. Una propuesta radical para una sociedad libre y una economía sensata (original en inglés 2017), trad. L. Lecuona y M.F. Miret, México, Libros Grano de Sal, 2017, págs. 49 y sigs., y bibliografía allí citada; MONEREO PÉREZ, J.L.: La renta mínima garantizada. De la renta mínima a la renta básica, Albacete, Ed. Bomarzo, 2018; CALVO GALLEGO, J.: "La renta básica universal e incondicionada y la lucha contra la pobreza en la ocupación: una primera aproximación”, dispone en https://idus.us.es/xmlui/bitstream/handle/11441/82102/La\%20renta\%20b\%C3\%A1sica\%20universal....pd f?sequence $=1 \&$ is Allowed $=y$.
} 
Es el nuestro un modelo de renta de inserción descentralizado y en gran medida desvertebrado por la inexistencia de una normativa estatal de renta mínima garantizada y, en todo caso, la falta de una mínima coordinación entre las rentas autonómicas. Por tanto tienen una configuración jurídica automática (Dejando a salvo la figura distinta de la RAI en el marco de la protección por desempleo, la cual está integrada en el sistema de Seguridad Social). En todos los casos, y como regla general, estamos ante rentas condicionadas a la concurrencia de determinados requisitos (señaladamente, comprobación del estado de necesidad y la indisponibilidad de recursos suficientes para atenderla) y que tienen un carácter subsidiario respecto de otros instrumentos de garantía de rentas obtenidas por el sujeto y la unidad familiar o unidad de convivencia, pues su finalidad es satisfacer la necesidades básicas tanto del sujeto beneficiario como de los restantes miembros que integran esa unidad convivencia en los términos jurídicamente relevantes. Las RMI se dirigen, pues, a las personas y a sus familias o unidades de convivencia. Pero sí hay un aspecto individualizador independiente del subsidio económico (proyectado hacia la unidad de convivencia), cual el compromiso del beneficio (y correlativa obligación de los poderes públicos de instrumentar lo necesario para garantizar su efectividad) de suscribir un compromiso de actividad encaminada a la reinserción (actividades formativas y aquellas que se determina que propicien o faciliten la inserción profesional). En esta perspectiva, la RMI mira a garantizar la efectividad del derecho al trabajo de las personas excluidas o que están incorporadas al mercado de trabajo.

Así la Ley 14/2017, de 20 de julio, de renta garantiza de ciudadanía (que desarrolla el art. 24.3 del Estatuto de Autonomía de Cataluña) ${ }^{76}$, sería un buen exponente paradigmático de estos rasgos configuradores. La renta garantizada de ciudadanía constituye la manifestación de varios principios: del principio de igualdad entendido como la eliminación de cualquier discriminación en el acceso a la prestación; del principio de equidad, puesto que el reconocimiento y la aplicación de la prestación se plantean como respuesta a la situación de necesidad desde una vertiente de redistribución de los recursos y de discriminación positiva; del principio de empoderamiento y autonomía de las personas en sociedad, entendido como el conjunto de prestaciones económicas y servicios que las fortalecen y les permiten salir de las situaciones de pobreza y necesidad, que deberían ser siempre transitorias y no cronificadas, y del principio de universalidad, solidaridad y complementariedad, pues se garantiza su acceso a todas las personas que reúnen los requisitos exigidos, constituye una manifestación de solidaridad y de justicia social y complementa los ingresos de sus destinatarios en situaciones de carencia de medios. Asimismo, responde al principio de subsidiariedad, puesto que la prestación se

\footnotetext{
${ }^{76}$ Ley Orgánica 6/2006, de 19 de julio, de reforma del EAC: "Las personas o las familias que se encuentran en situación de pobreza tienen derecho a acceder a una renta garantizada de ciudadanía que les asegure los mínimos de una vida digna, de acuerdo con las condiciones que legalmente se establezcan".
} 
reconoce cuando no es posible el acceso a otros mecanismos de protección, ya sea porque ha finalizado su cobertura o porque no han sido concedidos (Preámbulo) ${ }^{77}$.

Tienen derecho a la renta garantiza de ciudadanía las personas que cumplan los requisitos regulados por la presente ley (art. 5.1). No es una verdadera "renta básica"78. Esta Ley considerada destinatarios a los titulares y beneficiarios de la renta garantizada de ciudadanía (art. 5.2.c). Entiende por titular la persona en favor de la cual se aprueba la prestación económica de la renta garantizada de ciudadanía y, en su caso, un plan individual de inserción laboral o de inclusión social (art. 5.2.a), y por beneficiarios, las personas que forman parte del mismo núcleo como miembros de la respectiva unidad familiar (art. 5.2.b). Se deja constancia, por otra parte, "una unidad familiar solo puede dar derecho a un único expediente de prestación de renta garantizada de ciudadanía" (art. $5.4)^{79}$.

Paradigmática resulta, igualmente, la RMI Social de Andalucía (Decreto-Ley 3/2017, de 19 de diciembre, por el que se regula la Renta Mínima de Inserción Social en Andalucía). El enfoque y el modelo seguido -más allá de algunas similitudes- es matizadamente distinto al implantado en la Comunidad Autónoma de Cataluña. El objeto del DecretoLey es regular la prestación económica orientada a la erradicación de la marginación y la desigualdad y a la lucha contra la exclusión social, denominada Renta Mínima de Inserción Social en Andalucía, que deberá incorporar un itinerario a través de un Plan de

\footnotetext{
${ }^{77}$ La regulación y el desarrollo de la renta garantizada de ciudadanía responde también a otro grupo de principios que constituyen el marco de la actuación de las administraciones públicas en esta materia. Así, tiene en cuenta el principio de responsabilidad pública en la atención al ciudadano, ya que la provisión de la prestación se incardina en el sistema de servicios sociales y de empleo públicos, y su disponibilidad y gestión quedan garantizadas por las administraciones públicas en el ejercicio de sus competencias. Asimismo, la regulación de la prestación es una manifestación del principio de estabilidad, de modo que se mantiene la percepción de la prestación siempre y cuando persista la situación de exclusión social que la ha originado y el cumplimiento de los requisitos, las condiciones y las obligaciones establecidos. Del mismo modo, tiene en consideración el principio de atención individualizada. Por ello, la prestación debe responder en cada caso a las condiciones y necesidades particulares de sus destinatarios, sin olvidar, en su caso, las peculiaridades de los grupos o colectivos a los que pertenecen.

La participación de los destinatarios constituye, asimismo, un principio de atención inexcusable. Por ello se garantiza su contribución activa, comprometida y responsable en la superación de la situación, así como su intervención en la programación y desarrollo de los itinerarios que puedan diseñarse para la integración. Es también, sin duda, una prestación con un carácter de política familiar muy marcado, que protege a las familias y a los niños de las situaciones de vulnerabilidad. El carácter integral de la prestación da respuesta también a la pobreza infantil derivada de la existencia de familias con hijos en situación de extrema pobreza. Por último, se considera también la perspectiva de género, con el establecimiento de medidas de acción positiva que tienen en cuenta las necesidades especiales que presentan las víctimas de violencia de género. ${ }^{78}$ La Disposición derogatoria de la Ley 14/2017 incluye, significativamente, a la Ley 10/1997, de 3 de julio, de la RMI, "con las excepciones establecidas por las disposiciones transitorias de la presente Ley" (Ley 14/2017).

${ }^{79} \mathrm{Se}$ aporta un concepto instrumental de unidad familiar: "A los efectos de lo establecido por la presente ley se considera unidad familiar la formada por una o más personas que mantienen entre ellas vínculos familiares por consanguinidad o afinidad hasta el segundo grado, así como por adopción o acogimiento, o vínculos de convivencia asimilados a los vínculos mencionados, excluyendo los que sean de simple vecindad compartida. La relación de parentesco se cuenta a partir del titular" (art. 6.1 de la Ley 14/2017).
} 
inclusión sociolaboral, en los términos establecidos en los artículos 42.1 y 42.2.g) de la Ley 9/2016, de 27 de diciembre, de Servicios Sociales de Andalucía (Art. 1).

La ordenación normativa explicita la finalidad de este instrumento de protección social al indicar que "los fines de la Renta Mínima de Inserción Social en Andalucía son los siguientes: a) Reducir la tasa de pobreza y de exclusión social en Andalucía, especialmente la pobreza infantil. b) Mejorar las posibilidades de inclusión social y laboral de las personas en situación de pobreza, exclusión social o riesgo de estarlo, especialmente de aquellas que tienen menores a su cargo y teniendo en cuenta la diferente situación de los hombres y las mujeres. c) Aumentar el grado de autonomía personal y familiar y atender la satisfacción de las necesidades básicas para una vida digna de la unidad familiar "(Art. 6. Finalidad).

En cuanto a las Personas titulares y beneficiarias: Conforme al art. 6 de la Ley 9/2016, de 27 de diciembre, tendrán derecho a la Renta Mínima de Inserción Social en Andalucía, las unidades familiares cuyas personas miembros tengan vecindad administrativa en Andalucía, se encuentren en situación de pobreza, exclusión social o riesgo de estarlo, y cumplan los requisitos establecidos en el artículo 7 del presente Decreto-ley, así como aquellas que, aún no cumpliendo alguno de los requisitos, se encuentren en situación de urgencia o emergencia social. Podrán ser personas titulares de la Renta Mínima de Inserción Social en Andalucía las personas solicitantes y perceptoras con vecindad administrativa en cualquiera de los municipios de Andalucía y que forman parte de una unidad familiar pluripersonal o bien constituya por sí misma una unidad familiar unipersonal (art. 3).

El tercer modelo o paradigma relevante es el de la Renta de Garantía de Ingresos (RGI). Su regulación básica se establece en Ley 18/2008, de 23 de diciembre, para la Garantía de Ingresos y para la Inclusión Social ${ }^{80}$, y por el Decreto 147/2010, de 25 de mayo, de la Renta de Garantía de Ingresos (desarrollo de aquélla). El objeto de la Renta de Garantía de Ingresos es una prestación periódica de naturaleza económica, dirigida tanto a la cobertura de los gastos básicos para la supervivencia como a la de los gastos derivados de un proceso de inclusión social y/o laboral, y destinada a las personas integradas en unidades de convivencia que no dispongan de ingresos suficientes para hacer frente a dichos gastos (art. 1). La renta de garantía de ingresos se configura jurídicamente como una prestación periódica de naturaleza económica, dirigida a las personas integradas en una unidad de convivencia que no disponga de ingresos suficientes para hacer frente tanto a los gastos asociados a las necesidades básicas como a los gastos derivados de un proceso de inclusión social (art. 11; por su parte, el art. 2 delimita los objetivos perseguidos). Se estructura, además, como un verdadero derecho subjetivo: La renta de garantía de ingresos se configura como un derecho subjetivo para todas aquellas personas que cumplan los requisitos específicamente regulados para el acceso a la prestación en la

\footnotetext{
${ }^{80}$ La Disposición derogatoria, deroga la Ley 12/1998, de 22 de mayo; y deroga la Ley 10/2000, de 27 de diciembre, de Carta de los Derechos Sociales (modificada por la Ley 4/2007, de 22 de junio), sólo en los artículos 6,7 y 8.
} 
modalidad que resulte de aplicación (art. 12). De estas características destaca la configuración de un derecho de estructura jurídica compleja, pues se habla de un "doble derecho" (art. 3), en virtud del cual se reconoce a las personas tanto el derecho a acceder a medios económicos suficientes para hacer frente a las necesidades básicas de la vida como el derecho a disfrutar de apoyos personalizados orientados a la inclusión social y laboral. No excluye la posición de "deber", pero sí parece que éste se sitúa en un segundo plano.

El segundo elemento a retener también tiene que ver con el modelo de atención personalizada y de proximidad, ajustado al enfoque comunitario de la atención y la puesta en valor de su carácter preventivo (adviértase la relevancia que adquiere la dimensión preventiva en el cuadro finalista de la medida social instaurada). Así, en ese marco, otorgará prioridad a las actuaciones de prevención, facilitará, siempre que resulte posible y conveniente, la atención de las personas en su entorno habitual y garantizará la adaptación de las intervenciones a las necesidades de la persona o de la unidad convivencial, el carácter integral de dichas intervenciones y la continuidad de los itinerarios de atención (art. 4).

La titularidad del derecho se configura en términos muy amplios, distinguiendo entre personas titulares, destinatarias y perceptoras. $1^{\circ}$. Serán titulares de las prestaciones económicas de derecho y, en su caso, de los instrumentos de inclusión regulados en la presente ley las personas a nombre de quienes se tramita y concede la prestación y en quienes recae el derecho a la prestación o al convenio de inclusión. $2^{\circ}$. Tendrán la consideración de personas destinatarias de las prestaciones económicas de derecho y del convenio de inclusión las personas que formen parte de la misma unidad de convivencia que la titular. En el caso de las ayudas de naturaleza subvencional, tendrá la consideración de beneficiaria la persona a nombre de quien se tramita y a quien se concede la ayuda. $3^{\circ}$. Con carácter general, serán perceptoras de las prestaciones económicas de derecho reguladas en la presente ley las personas titulares de las mismas. En el caso de las ayudas de naturaleza subvencional, serán perceptoras, con carácter general, las personas beneficiarias de las mismas (art. 8).

Por otra parte, destinatarios de las medidas es también la "unidad de convivencia", concepto instrumental palpablemente se distingue de la unidad familiar (art. 9, en relación con el art. 8).

Un aspecto muy importante en la lógica interna de las instituciones es el relativo a la centralidad que ostenta el "Convenio de Inclusión" (art. 7).

Ciertamente, sobre la base del título competencial de "asistencia social" las CCAA han asumido la competencia en materia de Renta de Inserción. El resultado práctico ha sido una expansión de las medidas asistencializadoras de las CCAA, al amparo de una interpretación flexible del art. 148.1.20 $\mathrm{CE}$, que ha permitido incluir la innovadora figura de las rentas mínimas de inserción. El TC ha apreciado ya desde los orígenes de la instauración de este tipo de medidas la legitimidad de la inclusión en la competencia de 
asistencia social autonómica, entendiendo que no forman parte del Sistema de Seguridad Social, operando con técnicas diferentes a las que han venido caracterizando a la Seguridad Social clásica (muy marcada de los ya relativizados criterios de previsionalidad y de contributividad) (SSTC 146/1986, de 25 de noviembre, 76/1986, de 9 de junio, 13/1992, de 6 de febrero, 239/2002, de 11 de diciembre, 226/2012, de 19 de noviembre, 227/2012, de 29 de noviembre, etcétera), y también dando cuenta de la posterior evolución contemporánea hacia una seguridad social asistencial o no contributiva (realzando el componente asistencialista de la misma Seguridad Social). Estableciendo, esta línea, una distinción operativa entre una asistencia social "interna" al sistema institucional de la Seguridad Social y otra "externa" que sería de competencia exclusiva de las CCAA (SSTC 76/1986, de 9 de junio, 13/1992, de 6 de febrero, 239/2002, de 11 de diciembre, 226/2012, de 19 de noviembre, 227/2012, de 29 de noviembre). Admitido que las CCAA tienen una competencia propia en materia de asistencia social (asistencia externa al sistema de Seguridad Social) y que la Seguridad Social junto a la dimensión contributiva incorpora un componente asistencial, la delimitación de fronteras es más delicada obedeciendo a una decisión no meramente técnico-jurídica sino también de política del Derecho. De manera que no será suficiente distinguir entre previsión social y asistencia social (ésta se caracteriza, como es conocido, por la atención preferente a las situaciones objetivas de necesidad, por la inexigibilidad de la contributividad -al menos en vía principal-, y tendencialmente por incorporar una lógica universalista, aunque según el tipo de medidas puede remitirse a sujetos específicos y estar condicionada al cumplimiento de determinados requisitos; su concesión está normalmente condicionada) ${ }^{81}$, sino que es preciso establecer mecanismos de atribución competencial que garanticen espacios efectivos vitales de regulación de la materia asistencial tanto para las CCAA como para la Seguridad Social Asistencial. El debate y las iniciativas actuales en favor de un "sistema de Rentas Mínimas garantizadas en todo el Estado", con el que se atienda prioritariamente a los cerca de 740. 000 hogares que no tienen ningún tipo de ingresos, en los que viven, 1, 4 millones de personas; o incluso la más ambiciosa propuesta de implantación a nivel estatal -y en el marco de la Seguridad Social- de una "renta básica" o ingreso de ciudadanía universalista (e incondicionado; la cual en su lógica interna sobrepasa la idea misma de la asistencia social clásica abarcando una renovada asistencia social universalista que podría formar parte, potencialmente en términos constitucionales, de la Seguridad Social Asistencial ex art. $41 \mathrm{CE}$ ), ilustraría por sí mismo el hecho de que las fronteras son próximas y que lo que debe procurarse es respetar las respectivas garantías constitucionales de competencias en materia de asistencia social entre el Estado y las CCAA buscando soluciones coherentes y equilibradas (artículos 148.1.20 CE, y 149.1.17, en relación con el art. 41 y concordantes del Texto constitucional). Es relevante hacer notar que conforme al art. 34.3 ("Seguridad Social y ayuda social") de la Carta de los Derechos Fundamentales de la Unión Europea, "con el fin de combatir la exclusión social y la pobreza, la Unión reconoce y respeta el derecho a una ayuda social... para garantizar una existencia digna a todos aquellos que

${ }^{8181}$ Hay que tener en cuenta que el principio de la condicionalidad incorpora un criterio de intercambio funcional entre prestaciones y sujetos protegidos que da lugar a un sistema de obligaciones recíprocas. 
no dispongan de recursos suficientes, según las modalidades establecidas en el Derecho de la Unión y por las legislaciones y prácticas nacionales" $\$ 2$.

Con base al art. 148.1.20 $\mathrm{CE}$ las CCAA han venido asumiendo competencias en materia de asistencia social y servicios sociales, en cuyo marco autonómico se han incluido la renta mínima de inserción con distintas denominaciones. En todo caso, es necesario replantear el modelo en un doble sentido: racionalizándolo la heterogeneidad de rentas de inserción (con distintas denominaciones, por otra parte) establecidas en las CCAA, simplificándolo y coordinando los distintos tipos de medidas, por un lado, y por otro, pensar seriamente en establecer una renta básica a nivel de todo el Estado Social Autonómico, que pudiera ser completada o mejoradas por cada CCAA. Por lo demás, no es baladí hacer notar que ese reajuste de la medida se impondría porque una renta básica incluida dentro de la Seguridad Social Asistencial (en su vertiente no contributiva) provocaría automáticamente la incorporación al Reglamento 883/2004, de 29 de abril, en cuyo art. 3.5 se excluye expresamente de las normas de coordinación comunitaria a las prestaciones asistenciales. Aparte de ello, existen iniciativas, todavía muy poco desarrolladas, de establecer una "renta mínima europea" (Véase, señaladamente, el Dictamen del CESE sobre "la renta mínima europea e indicadores de pobreza (Dictamen de iniciativa)", 2014/C 170/04, DOCE, 5.6.2014). El impulso más significativo es la Resolución del Parlamento Europeo, de 24 de octubre de 2017, sobre las políticas encaminadas a garantizar la renta mínima como instrumento para luchar contra la pobreza (2016/2270/(INI)).

Debe ser objeto prioritario de la iniciativa legislativa y de la concertación social la propuesta de un Sistema de Rentas Mínimas Garantizadas en España. Las actuales prestaciones sociales de índole asistencial se caracterizan por la diversidad y las diferencias territoriales y por un nivel de cobertura claramente insuficiente. Las instituciones de la Unión Europea vienen promoviendo desde hace tiempo diversas propuestas para el desarrollo de sistemas de rentas mínimas y otros instrumentos de lucha contra la pobreza y la exclusión social. La propia Comisión Europea ha propuesto reforzar la relación entre rentas mínimas y activación laboral, diseñando el concepto de "inclusión activa" ("conjunto de procesos sociales e institucionales que desarrollan el derecho de todo ciudadano a la plena integración en la sociedad, al ejercicio de sus derechos sociales y de manera particular a la inserción laboral y social”) e instando a las políticas públicas $\mathrm{y}$ a los agentes sociales para promover acciones y programas que hagan frente a las importantes insuficiencias de los sistemas de protección contra el riesgo de pobreza y o exclusión, riesgos sin duda modificados e incrementados como consecuencia de la intensidad y la duración de la crisis económica.

\footnotetext{
${ }^{82}$ Véase MONEREO PÉREZ, J.L.: "Los derechos a la Seguridad Social y a la Ayuda Social (Artículo 34)", en VV.AA.: La Europa de los derechos. Estudio sistemático de la Carta de los Derechos Fundamentales de la Unión Europea, Monereo Atienza, C. y Monereo Pérez, J.L. (Dirs. y Coords.), Granada, Ed. Comares, 2012, págs. 893 y sigs.
} 
Hay que tener en cuenta que el debate sobre la instauración de una "renta mínima europea” ya está planteado en el marco de las instituciones de la Unión Europea. Así el Comité Económico y Social Europeo (CESE) entiende que atendiendo a las previsiones de conformación de los mercados de trabajo y a la difícil coyuntura actual, el establecimiento de una renta mínima europea, contribuirá a la cohesión económica, social y territorial, a la protección de los derechos humanos fundamentales, al equilibrio entre los objetivos económicos y sociales y al reparto equitativo de los recursos y la reta. Realza que es acuciante la necesidad de garantizar una renta mínima adecuada en la Unión Europea mediante una Directiva Marco dirigida a combatir la pobreza y la exclusión social, facilitando la inserción en el mercado de trabajo, tal y como han solicitado también el Comité de las Regiones y varias organizaciones de lucha contra la pobreza y la exclusión social, e insta a la Comisión Europea a emprender una acción concertada que responda a la Resolución adoptada por el Parlamento Europeo (Resolución del Parlamento Europeo, de 15 de noviembre de 2011, sobre la plataforma europea contra la pobreza y la exclusión social; 2011/2052/(INI), DOC 153E de 31.5. 2013, pp. 57-78). La renta mínima garantizada es una ayuda a los ingresos que no está basada en el pago de cotizaciones (contributividad) y que proporciona una red de seguridad para las personas que no pueden optar a las prestaciones de la Seguridad Social. Como última salvaguarda contra la pobreza y exclusión social, está indisolublemente unida al derecho a llevar una vida digna de las personas que no tienen otra forma de asegurar sus ingresos y al de las personas que están a su cargo. (Véase Dictamen del Comité Económico y Social Europeo sobre la renta mínima europea e indicadores de pobreza (Dictamen de Iniciativa), aprobado los días 10-11 de diciembre de 2013. 2014/C 170/04; y el Dictamen del Comité Económico y Social Europeo (CESE), "Por una Directiva marco europeo sobre la renta mínima” [Dictamen de iniciativa], aprobada en pleno $n^{\circ} .541$, el 20. 02.2019 ${ }^{83}$ ).

En consecuencia, en el marco de las políticas legislativas concertadas se debe situar la propuesta de un Sistema de Rentas Mínimas Garantizadas común para toda España (Estados Social Autonómico), que tenga carácter estructural y voluntad de permanencia y que se regule mediante una ley estatal. Se trataría con ello de hacer efectivo el derecho a percibir unos ingresos mínimos de subsistencia y de establecer medidas de apoyo dirigidas a conseguir la inclusión sociolaboral, reconociendo este derecho con carácter subjetivo.

\section{El Ingreso Mínimo Vital como renta mínima dentro del Sistema institucional de la Seguridad Social No Contributiva.}

\subsection{El problema social subyacente como telón de fondo.}

Como se constata en la Exposición de Motivos del Real Decreto-ley 20/2020, de 29 de mayo, por el que se establece el ingreso mínimo vital (en adelante, LIMV), España se

\footnotetext{
${ }^{83}$ SOC/585- EESC-2018-02210.00-00-AC-TRA (EN) 1/16- Ponente: Georges Dassis.
} 
encuentra entre los países de la Unión Europea con una distribución de la renta entre hogares más desigual. Existe un eleva nivel de desigualdad, con situaciones de pobreza extrema y no sólo de desventaja social. Se aportan datos significativos al respecto y se indica que aunque las causas de estas altas tasas de desigualdad y pobreza son múltiples, un factor común es el débil efecto redistributivo del conjunto de la intervención del Estado en España en comparación con la mayoría de los países de nuestro entorno. Dicha debilidad deriva en parte del menor desarrollo y financiación de partidas con claro impacto redistributivo (en especial la ausencia de una política estatal de garantía última de ingresos, como existe en la mayor parte de los países europeos), y en parte también por el diseño concreto que han tomado las políticas públicas.

Ante esta realidad, han sido las comunidades y ciudades con Estatuto de Autonomía las que han ido configurando diferentes modelos de políticas de rentas mínimas. Estos sistemas han desempeñado un papel muy relevante para la atención de las personas en situación de vulnerabilidad, tanto en los momentos de crisis económica como en las etapas de crecimiento. Sin embargo, se trata de modelos muy diferentes entre sí, con variaciones muy sustanciales en su diseño, y especialmente en sus grados de cobertura y nivel de protección. El resultado ha sido una heterogeneidad significativa en el acceso a las prestaciones sociales de las personas en situación de necesidad, muchas de las cuales continúan sin ser suficientemente cubiertas por nuestro Estado del bienestar. Estas debilidades del sistema de garantía de ingresos español han sido puestas de manifiesto de manera recurrente en informes y recomendaciones procedentes de las instituciones europeas. Así, en la recomendación del Consejo relativa al Programa Nacional de Reformas de 2018 de España, se afirma que «el impacto de las transferencias sociales en la reducción de la pobreza está por debajo de la media europea y está bajando. Los programas de garantía de rentas están marcados por grandes disparidades en las condiciones de acceso y entre regiones, y por la fragmentación de los programas destinados a diferentes grupos de individuos en búsqueda de empleo y gestionados por diferentes administraciones» (punto 12). En la Recomendación de 2019, se afirma que «la proporción de personas en riesgo de pobreza y exclusión social, así como la desigualdad de ingresos sigue estando por encima de la media de la Unión (...). La pobreza infantil, aunque se está reduciendo, sigue siendo muy alta.» (punto 14).

También en el marco comunitario, el Pilar Europeo de Derechos Sociales, adoptado en la Cumbre social en favor del empleo justo y el crecimiento celebrada en Gotemburgo en noviembre de 2017, pretende dar a los ciudadanos europeos unos derechos sociales nuevos y más efectivos. Este Pilar Europeo de Derechos Sociales establece veinte principios fundamentales, uno de los cuales (principio 14) está dedicado a la renta mínima, señalando que: «Toda persona que carezca de recursos suficientes tiene derecho a unas prestaciones de renta mínima adecuadas que garanticen una vida digna a lo largo de todas las etapas de la vida, así como el acceso a bienes y servicios de capacitación. Para las personas que pueden trabajar, las prestaciones de renta mínima deben combinarse con incentivos a la (re)integración en el mercado laboral». 
Por otra parte, con el fin de prevenir y luchar contra la pobreza y la exclusión social en España, por Acuerdo del Consejo de Ministros de 22 de marzo de 2019 se aprobó la Estrategia Nacional de Prevención y Lucha contra la Pobreza y la Exclusión Social 20192023. Entre otros elementos, la estrategia identifica la reducción de la desigualdad de rentas entre los principales desafíos de las sociedades europeas y en España en particular.

Estos problemas ya existían, por causas estructurales y deficiencias del sistema general de protección social pública, pero a mayor abundancia la necesidad de instaurar un medida de renta mínima o de ingreso mínimo vital como política destinada a corregir estos problemas se ha visto "acelerada" por la crisis sanitaria del COVID-19 y el estado de alarma declarado por el Real Decreto 463/2020, de 14 de marzo. Más allá del impacto directo sobre la actividad económica, la pandemia ha desembocado en una profunda crisis social, que afecta especialmente a las personas en situación de vulnerabilidad. De ahí el establecimiento como medida de urgencia -y en el marco del Derecho de la emergencia actual, aun siendo una medida de carácter estructural y permanente- un mecanismo de garantía de ingresos de ámbito nacional. Este mecanismo, articulado a partir del mandato que el art. $41 \mathrm{CE}$ otorga al régimen público de Seguridad Social para garantizar la asistencia y prestaciones suficientes ante situaciones de necesidad, asegura un determinado nivel de rentas a todos los hogares en situación de vulnerabilidad con independencia del lugar de residencia. Materializando esa finalidad se aprueba el IMV como prestación económica de la Seguridad Social en su modalidad no contributiva.

Es en este contexto -como se percibe de carácter estructural y no limitado a la situación coyuntural de la tragedia de la Pandemia Covid-19-, donde hay que enmarca el Real Decreto-ley 20/2020, de 29 de mayo, por el que se establece el ingreso mínimo vital (BOE 01-06-2020) ${ }^{84}$ (en adelante, LIMV). El real decreto-ley tiene por objeto la creación y regulación del ingreso mínimo vital (IMV) como prestación dirigida a prevenir el riesgo de pobreza y exclusión social de las personas que vivan solas o integradas en una unidad de convivencia, cuando se encuentren en una situación de vulnerabilidad por carecer de recursos económicos suficientes para la cobertura de sus necesidades básicas. El ingreso mínimo vital se configura como el derecho subjetivo a una prestación de naturaleza económica que garantiza un nivel mínimo de renta a quienes se encuentren en situación de vulnerabilidad económica (es decir, con referencia a las personas más desfavorecidas, los pobres -en sentido absoluto, indigentes- o relativo, con insuficiencia grave de recursos-, los marginados y los excluidos por falta de trabajo o ser "trabajadores pobres") en los términos que se definen en el real decreto-ley. El Ingreso Mínimo Vital es una nueva prestación de la Seguridad Social que va acompañada de estrategias de inclusión

\footnotetext{
${ }^{84}$ El Congreso convalidó este Real Decreto-ley por el que se establece el Ingreso Mínimo Vital. Cfr. Resolución de 10 de junio de 2020, del Congreso de los Diputados, por la que se ordena la publicación del Acuerdo de convalidación del Real Decreto-ley 20/2020, de 29 de mayo, por el que se establece el ingreso mínimo vital. De conformidad con lo dispuesto en el art. 86.2 de la Constitución, el Congreso de los Diputados, en su sesión del día de hoy, acordó convalidar el Real Decreto-ley 20/2020, de 29 de mayo, por el que se establece el ingreso mínimo vital, publicado en el "BOE" número 154, de 1 de junio de 2020. Se ordena la publicación para general conocimiento. Palacio del Congreso de los Diputados, 10 de junio de 2020.-La Presidenta del Congreso de los Diputados, Meritxell Batet Lamaña.
} 
focalizadas. El IMV, que será de carácter permanente dentro del cuadro del catálogo prestacional de la Seguridad Social, tiene como principales objetivos la redistribución de la renta, con la intención de erradicar la pobreza extrema, y la inclusión social y participación en el mercado laboral de las personas en situación de vulnerabilidad. El IMV es la respuesta del Gobierno de coalición al problema estructural de pobreza que existe en España y que hasta ahora no ha sido suficientemente atajado por las políticas y medidas protectoras existentes, como han puesto de manifiesto en numerosas ocasiones las recomendaciones remitidas a España desde diferentes organismos internacionales ${ }^{85} \mathrm{y}$, por supuesto, la doctrina científica. Su puesta en marcha se ha acelerado ${ }^{86}$ para ayudar a

\footnotetext{
${ }^{85}$ No es baladí hacer notar que esta medida del IMV ha sido valorada muy positivamente por la Directora del Fondo Monetario Internacional, Kristalina Georgieva, quien en respuesta a la pregunta "España ha aprobado una renta mínima vital para familias vulnerables. ¿Cree que debería ser una herramienta permanente o solo adscrita a esta crisis?" responde con contundencia: "Primero, bravo. España ha adoptado una medida apropiada para proteger a las personas más vulnerables de esta crisis y, segundo, sí, tiene lógica hacerla permanente. Con la advertencia de que hay también instrumentos regionales y se tiene que hacer algo de trabajo para asegurarse de que hay una coherencia, de que no se producen solapamientos que generen injusticias. La pobreza en España es más alta en comparación con la eurozona, especialmente entre los niños. Un 21\% de la población se encuentra bajo el umbral de la pobreza, cuando en la Unión Europea es menor del $17 \%$. En cuanto a gente en riesgo de pobreza, España estaba en el $26 \%$ y la UE, en el $22 \%$. En otras palabras, España ha hecho un trabajo importante para mejorar en igualdad y este es un buen instrumento. Al salir de esta crisis debemos construir estabilizadores de protección social". Entrevista en el Diario ELPAIS, Sección “Economía y Trabajo", Lunes 15 de junio de 2020, págs. 38-39, en particular pág. 39.

${ }^{86}$ COALICIÓN PROGRESISTA (PSOE/UNIDAS PODEMOS): Un nuevo Acuerdo para España, Madrid, a 30 de diciembre de 2019. En cualquier caso, ya había iniciativas en marco del Derecho Internacional y en la propia Unión Europea. No sólo es su amparo directo en el art. 34 de la Carta de los Derechos Sociales Fundamentales de la Unión Europea, sino también el instrumento de "Derecho blanco" (soft law), el cual ha adquirido una gran relevancia en el "Derecho comunitario", aunque en sí importante en el plano de la política del Derecho, del Pilar Europeo de Derechos Sociales -dicho instrumento se aprobaría en la Cumbre de la Unión Europea de noviembre de 2017, y en cuyo apartado 14, establece que "Toda persona que carezca de recursos suficientes tiene derecho a unas prestaciones de renta mínimas adecuadas que garanticen una vida digna a lo largo de todas las etapas de la vida, así como el acceso a bienes y servicios de capacitación. Para las personas que puedan trabajar, las prestaciones de renta mínima deben combinarse con incentivos a la (re)integración en el mercado laboral". Véase, la Comunicación de la Comisión al Parlamento Europeo, al Consejo y al Comité de las Regiones, "Apertura de una consulta sobre un pilar europeo de derechos sociales", Estrasburgo, 8.3.2016 COM(2016) 127 final. Consúltese, MONEREO PÉREZ, J.L.: "Pilar Europeo de Derechos Sociales y sistema de seguridad social", en Lex Social. Revista de Derechos Sociales, Vol. U, Núm. 2 (2018), págs. 251-298; MONEREO PÉREZ, J.L.: La renta mínima garantizada. De la renta mínima a la renta básica, Albacete, ed. Bomarzo, 2018, págs. 7 y sigs., en particular pág. 10. Para un estudio sobre del alcance comprensivo de las rentas mínimas en el art. 34 de la Carta de los Derechos Fundamentales de la Unión Europea, véase MONEREO PÉREZ, J.L.: "Seguridad Social y Ayuda Social (Artículo 34 de la Carta de la UE)", en VV.AA.: La Europa de los Derechos. Estudio Sistemático de la Carta de los Derechos Fundamentales de la Unión Europea, Monereo Atienza, C. y Monereo Pérez, J.L. (Dirs. y Coords.), Granada, ed. Comares, 2012, págs. 893 y sigs.; y reforzando el análisis de la necesaria perspectiva de la garantía multinivel de los derechos fundamentales, véase MONEREO PÉREZ, J.L. y ORTEGA LOZANDO, P.G.: "Derecho a a protección contra la pobreza y la exclusión social (artículos 30 de la Carta Social Europea", en VV.AA.: La garantía multinivel de los derechos fundamentales en el Consejo de Europa. El Convenio Europeo de Derechos Humanos y la Carta Social Europea, Monereo Atienza y Monereo Pérez, J.L. (Dirs. y Coords.), Granada, ed. Comares, 2017, págs. 925 y sigs. Asimismo, MONEREO PÉREZ, J.L.: "La garantía internacional y europea de los derechos a la Seguridad Social y Asistencia Social", en VV.AA.: Estudios sobre Seguridad Social. Libro Homenaje al Profesor José Ignacio García Ninet, Madrid, ed. Atelier, 2017, págs. 187-245.
} 
cubrir las situaciones de vulnerabilidad causadas por la COVID-19, que se suman a las de las familias que ya se encontraban en dificultades previamente.

El IMV adopta una decisión de política del Derecho de gran envergadura porque asume como propia y legítima la iniciativa de establecer una nueva medida de garantía de rentas que antes sólo estaba encomendada a las Comunidades Autónomas a través de sus instrumentos "asistenciales" con distintas denominaciones. Es obvio que no estamos ante una "recentralización", sino más bien ante una racionalización motivada por la necesidad de establecer una solución homogénea y coherente para todo el territorio español, cubriendo las limitaciones intrínsecas y extrínsecas de las rentas mínimas disponibles por las Comunidades Autónomas. Pero con ello se realiza la finalidad propia de la Seguridad Social tal como viene establecida en el art. 41 de la Norma Fundamental.

El IMV es toda una política social que constituye un nuevo pilar prestacional de nuestro Sistema institucional de Seguridad Social (art. $41 \mathrm{CE}$ y normas concordantes del bloque normativo constitucional regulador de la Seguridad Social) y que se engarza alrededor de una prestación, de forma que, más allá de la ayuda monetaria incluye estrategias de inclusión, en coordinación con las comunidades autónomas y los ayuntamientos, que permitan a las personas en situación de vulnerabilidad económica transitar a una situación mejor que les permite una inclusión social efectiva en una sociedad democrática. Los beneficiarios contarán con incentivos a la contratación y también se creará un "Sello Social" para las empresas que les ofrezcan formación y empleo.

Además, se fomentará la participación en el mercado laboral con incentivos. Cuando el titular de la prestación no tenga empleo y lo encuentre, parte de su salario estará exento transitoriamente en el cálculo de la prestación. En el caso de que esté ocupado, cuando su salario se incremente, la cuantía de la prestación se reducirá en una cantidad inferior. En el caso de que el titular no esté ocupado, se exigirá la inscripción como demandante de empleo para el acceso a la prestación.

Para el reconocimiento de la prestación se tendrán en cuenta los ingresos del año inmediatamente anterior, aunque para atender las situaciones de vulnerabilidad generadas por la pandemia de COVID-19, también se podrá reconocer para solicitudes cursadas durante 2020 teniendo en cuenta la situación de ingresos de este año.

El resultado del Ingreso Mínimo Vital y de las distintas estrategias y políticas de inclusión será evaluado anualmente por la Autoridad Independiente de Responsabilidad Fiscal (AIReF), mediante la emisión de la correspondiente opinión.

\subsection{Rasgos fundamentales del Ingreso Mínimo Vital.}

$\left.1^{a}\right)$. Finalidad: lucha contra la pobreza y la desigualdad a través de la garantía de ingreso y la igualdad de oportunidades. La ordenación es nítida en su propio tenor literal, cuando delimita el objeto del real decreto-ley, indicando que "tiene por objeto la creación y regulación del ingreso mínimo vital como prestación dirigida a prevenir el riesgo de pobreza y exclusión social de las personas que vivan solas o integradas en una unidad de 
convivencia, cuando se encuentren en una situación de vulnerabilidad por carecer de recursos económicos suficientes para la cobertura de sus necesidades básicas" (art. 1. Objeto). Subyace la idea-fuerza de establecer una prestación económica que cubra el riesgo general de pobreza y de exclusión social.

Esta prestación nace con el objetivo principal de garantizar, a través de la satisfacción de unas condiciones materiales mínimas, la participación plena de toda la ciudadanía en la vida social y económica, rompiendo el vínculo entre ausencia estructural de recursos y falta de acceso a oportunidades en los ámbitos laboral, educativo, o social de los individuos. La prestación no es por tanto un fin en sí misma, sino una herramienta para facilitar la transición de los individuos desde la exclusión social que les impone la ausencia de recursos hacia una situación en la que se puedan desarrollar con plenitud en la sociedad. Aunque la situación de privación económica que sufren las personas a las que va dirigida esta medida esté en el origen de su situación de vulnerabilidad, la forma concreta que tomará su inclusión social variará en función de las características de cada individuo: para algunos, será el acceso a oportunidades educativas, para otros, la incorporación al mercado de trabajo o, la solución a una condición sanitaria determinada. Este objetivo de inclusión condiciona de manera central el diseño de la prestación, que, incorporando las mejores prácticas internacionales, introduce un sistema de incentivos buscando evitar la generación de lo que los expertos en política social han llamado «trampas de pobreza», esto es, que la mera existencia de prestación inhiba el objetivo de inclusión social y económica de los receptores. Para aplicar este sistema de incentivos, resulta fundamental la cooperación con las comunidades autónomas y entidades locales en el despliegue de unos itinerarios de inclusión flexibles y adaptados a cada situación para los beneficiarios del ingreso mínimo vital, dado que, en el ejercicio de sus competencias, pueden acceder de manera más directa a las realidades concretas de los perceptores a través de los servicios sociales, pieza clave en la articulación del sistema. El sector privado también será copartícipe del diseño de estos itinerarios de inclusión, estableciéndose un Sello de Inclusión Social que acredite a todas aquellas empresas que ofrezcan oportunidades de empleo y formación a los perceptores del ingreso mínimo vital. El IMV no es, pues, una política dirigida apriorísticamente a grupos o individuos concretos, sino que, atendiendo a aquellos que en un momento determinado sufren situaciones de exclusión y vulnerabilidad, protege de forma estructural a la sociedad en su conjunto. Esta política actuará así como un seguro colectivo frente a los retos que nuestras sociedades enfrentarán en el futuro próximo: carreras laborales más inciertas, nuevas vulnerabilidades, transformaciones económicas asociadas a la robotización o el cambio climático, y en general una mayor volatilidad en los ingresos y los empleos, problemas frente a los que casi nadie será inmune, pero que afectarán especialmente a los grupos sociales más vulnerables (Véase Exposición de Motivos de la LIMV). 
$2^{\mathrm{a}}$ ). Prestación de Seguridad Social no contributiva y, por tanto, inserta en el Sistema institucional de la Seguridad Social ${ }^{87}$. Debe destacarse al respecto una multiplicidad encadenada de títulos competenciales. Este real decreto-ley - establece la Disposición final novena, relativa al Título competencial- "se dicta al amparo de lo dispuesto en el artículo 149.1.1. $.^{\mathrm{a}}, 13 .^{\mathrm{a}}, 14 .^{\mathrm{a}}, 17 .^{\mathrm{a}}$ y 18. ${ }^{\mathrm{a}}$ de la Constitución Española, que atribuye al Estado la competencia exclusiva sobre la regulación de las condiciones básicas que garanticen la igualdad de todos los españoles en el ejercicio de los derechos y en el cumplimiento de los deberes constitucionales; bases y coordinación de la planificación general de la actividad económica; hacienda general y deuda del Estado; legislación básica y régimen económico de la Seguridad Social; y bases del régimen jurídico de las administraciones públicas y el procedimiento administrativo común". Adviértase que la "legislación básica" ex art. 149.1.17 $\mathrm{CE}$ presupone la posibilidad de que las Comunidades Autónomas puedan dictar una legislación no básica ostentando, de asumirlas, una competencia compartida que va más allá de la simple ejecución de la competencia "exclusiva" estatal por los órganos administrativos de dichas Comunidades Autónomas $^{88}$. La STC 239/2002, de 11 de diciembre ${ }^{89}$, vino a dar una apertura constitucional a la competencia autonómica para completar las medidas de Seguridad Social establecidas por la legislación estatal (en cuyo Fallo se desestiman los conflictos positivos de competencia promovidos por el Gobierno de la Nación frente a los Decretos de la Junta de Andalucía 284/1998, por el que se establecen ayudas económicas complementarias a favor de pensionistas por jubilación e invalidez en sus modalidades no contributivas, y 62/1999, de modificación del Decreto 284/1998, y declarar que la competencia controvertida corresponde a la Comunidad Autónoma).

No estamos ante una prestación de carácter asistencial, ni tampoco ante una prestación técnica de servicios sociales, aunque requiera de prestaciones serviciales de carácter accesorio y que se utilice en su materialización de la colaboración activa de las Comunidades Autónomas. La legitimidad y oportunidad constitucional es evidente atendiendo a los títulos competenciales, los cuales se vinculan directa y funcionalmente con el art. 41 de la Norma Fundamental.

La medida del IMV -y su progresivo perfeccionamiento- supondrán un avance importante en la construcción expansiva de nuestro Modelo de Seguridad Social. Su

\footnotetext{
${ }^{87}$ Esta configuración jurídica de la medida había sido realizada ya expresamente por la doctrina científica, MONEREO PÉREZ, J.L.: La renta mínima garantizada. De la renta mínima a la renta básica, Albacete, ed. Bomarzo, 2018, espec., Capítulo 3.2. "La propuesta de racionalización a través de la reconducción de las rentas mínimas autonómicas en el Sistema de Seguridad Social: la creación de una renta mínima garantizada a nivel estatal", págs. 98 y sigs.; Ibid., "La renta Mínima para las familias sin recursos", en ASOCIACIÓN ESPAÑOLA DE SALUD Y SEGURIDAD SOCIAL: Protección a la familia y Seguridad Social. Hacia un nuevo modelo de protección sociolaboral, II Congreso Internacional y XV Congreso Nacional de la AESSS, celebrado en Madrid, octubre de 2018, publicado en Murcia, ed. Laborum, 2018, págs. 831 y sigs.

${ }^{88}$ MONEREO PÉREZ, J.L.: "El derecho a la Seguridad Social (Art. 41 CE)”, en VV.AA.: Comentario a la Constitución Socio-Económica de España, Monereo Pérez, J.L., Molina Navarrete,C. y Moreno Vida, M.N. (Dirs. y Coords.), Granada, Ed. Comares, 2002, pág. 1495.

${ }^{89}$ BOE núm. 9, de 10 de enero de 2003.
} 
establecimiento permitirá equilibrar la configuración de un modelo integrado por una doble esfera, contributiva y no contributiva, en el que esta segunda ha sido hasta ahora un elemento secundario en términos de conjunto. El IMV supondrá una profundización de este último ámbito no contributiva de la Seguridad Social.

La Constitución ofrece un marco especialmente favorable para esta profundización de esta vector de no contributivo de la Seguridad Social, sin detrimento del segmento contributivo. Así lo ha declarado el Tribunal Constitucional respecto al art. $41 \mathrm{CE}$ (en interpretación sistemática con los artículos 1 y 9.2), la doctrina constitucional concibe la Seguridad Social como una «función del Estado» que atiende a cambiantes situaciones de necesidad (SSTC 37/1994; 65/1987). Pero también atendiendo al ideal de cobertura que se recoge en el estándar multinivel de garantía del derecho a la Seguridad Social (artículos 10.2 y 96 de Texto Constitucional) ${ }^{90}$.

Aunque hay que establecer las líneas más nítidas de demarcación conviene retener que conforme al art. 8. 3, "A efectos de este real decreto-ley, no computarán como ingresos los salarios sociales, rentas mínimas de inserción o ayudas análogas de asistencia social concedidas por las comunidades autónomas, y otros ingresos y rentas de acuerdo con lo previsto en el artículo 18". Por lo tanto la regla es de compatibilidad. Ahora bien, admitido que no estamos ante una medida asistencial del art. 148.20 CE, sino ante una medida típica de Seguridad Social no contributiva o asistencial interna a dicho sistema institucional, la cuestión residirá en establecer los nexos de relación y las posibilidades de "legislación no básica" que ofrece el mismo art. 149.1.17 CE, pues sólo hay una reserva de competencia exclusiva en lo que se refiere literalmente a la "legislación no básica" (a diferencia de lo que acontece respecto de la legislación laboral ex art. 149.1.7 $\mathrm{CE}$ ). También el desarrollo reglamentario podría establecer vías de engarce y de solución preventiva de posibles conflictos de competencia, que en términos de principio aquí no existen (Recuérdese que con arreglo a lo previsto en el art. 8.5, "Reglamentariamente se podrán establecer, para supuestos excepcionales de vulnerabilidad que sucedan en el mismo ejercicio, los supuestos y condiciones en los que podrán computar los ingresos y rentas del ejercicio en curso a los efectos de acceso a esta prestación". Pero habría que entrar más sutil y nítidamente en el acoplamiento estructural y funcional entre los respectivos ámbitos competenciales del Estado (Seguridad Social no contributiva) y de las Comunidades Autónomos (Asistencia Social).

\footnotetext{
${ }^{90}$ MONEREO PÉREZ, J.L.: "Derecho a la Seguridad Social y Asistencia Social (art. 22 DUDH; art. 9 PIDESC)", en VV.AA.: El sistema Universal de los Derechos Humanos, Monereo Atienza, C. y Monereo Pérez, J.L. (Dirs. y Coords.), Granada, ed. Comares, 2014, págs. 515 y sigs.; Ibid., "Derechos a la Seguridad Social (Art. 12 de la Carta Social Europea)", en VV.AA.: La garantía multinivel de los derechos fundamentales en el Consejo de Europa. El Convenio Europeo de los Derechos Humanos y la Carta Social Europea, Monereo Atienza, C. y Monereo Pérez, J.L. (Dirs. y Coords.), Granada, ed. Comares, 2017, págs. 629 y sigs.; Ibid., "Seguridad Social y ayuda social" (Art. 34 de la Carta de la UE)", en VV.AA.: La Europa de los Derechos. Estudio Sistemático de la Carta de los Derechos Fundamentales de la Unión Europea, Monereo Atienza, C. y Monereo Pérez, J.L. (Dirs. y Coords.), Granada, ed. Comares, 2012, págs. 893 y sigs.
} 
Es ésta una medida que perfecciona el "ideal de cobertura" en la lógica evolutiva que ha inspirado siempre el desarrollo de la seguridad social: la invención de sistemas prestacionales que hagan frente a las nuevas necesidades sociales dentro de la socialización pública (o nacionalización estatal) de su cobertura solidaria ${ }^{91}$.

El IMV o renta mínima vital configurada como prestación no contributiva de Seguridad Social permite una protección pública homogénea para todas las personas -individuales o en unidades de convivencia- en todo el Estado español, sobrepasando el carácter invertebrado y dispar actual de las rentas mínimas territorializadas por Comunidades Autónomos. Ello sin perjuicio de reconocer la aportación extraordinaria que se ha llevada a cabo por el Estado Social Autonómico en esta materia. Pero esta nueva renta mínima de ámbito estatal inserta en el Sistema de Seguridad Social era ya necesaria para hacer frente a las situaciones protegidas y superar los límites de las rentas mínimas autonómicas ${ }^{92}$.

Siendo ello así, lo más lógico es que esta prestación específica se incluyera directamente en el RD-Legislativo 8/2015, de 30 de octubre, por el que se aprueba el Texto Refundido de la Ley General de Seguridad Social, y como un capítulo separado del Título VI, relativo a las "Prestaciones no contributivas". Tanto más, dado que se configura no como una prestación de carácter excepcional respecto al sistema general vigente, sino como una prestación permanente del Sistema. Por tanto, es criticable técnicamente que no se haya insertado en dicho Título. Y debería hacerse lo antes posible para subsanar esta deficiencia de técnica legislativa, que tiene además el inconveniente de política del Derecho de hacer visible una supuesta provisionalidad (y esto dejar mal situada a esta medida) de una medida que en su concepción ya originaria no la tiene (a pesar de algunas presiones políticas).

$3^{\mathrm{a}}$ ).-La financiación es íntegramente estatal con cargo a presupuestos generales del Estado. La financiación del ingreso mínimo vital se realizará a cargo del Estado mediante la correspondiente transferencia a los presupuestos de la Seguridad Social (Cap. VI LIMV).

$4^{\text {a }}$ ).-La gestión es pública y residenciada en el INSS para garantizar su homogeneidad al igual que las demás prestaciones del sistema de Seguridad Social, sin perjuicio de la colaboración en la gestión por parte de las Comunidades Autónomas; las cuales - no se olvide- al amparo del art. 149.1.17 ${ }^{a}$ pueden asumir una legislación no básica, que lógicamente respete ese núcleo esencial básico, sin el cual se produciría una disfuncional regulación asimétrica de esta institución prestacional de Seguridad Social.

\footnotetext{
${ }^{91}$ En la perspectiva histórica de desarrollo de las políticas de Seguridad Social, MONEREO PÉREZ, J.L.: "Los (pre)supuestos histórico-institucionales de la Seguridad Social en la constitución social del trabajo", en ROJAS RIVERO, G. (Coord.): Orígenes del contrato de trabajo y nacimiento del Sistema de Protección Social, Albacete, ed. Bomarzo, 2012, págs. 203-328.

${ }^{92}$ En este sentido MONEREO PÉREZ, J.L.: La Renta Mínima Garantizada. De la Renta Mínima a la Renta Básica, Albacete, ed. Bomarzo, 2018, cap. 3 ("El modelo español de rentas mínimas de inserción o de renta garantizada de ciudadanía"), págs. 57 y sigs.
} 
El INSS será el organismo competente para el reconocimiento y control de la prestación, sin perjuicio de la posibilidad de suscribir convenios y de las disposiciones adicionales cuarta y quinta. La tramitación del procedimiento se realizará por medios telemáticos. Es indispensable evitar que los procedimientos burocráticos de reconocimiento del derecho al IMV acaben siendo intimidatorios y estigmatizadores que desincentiven la incorporación efectiva al programa de ayuda social proactiva.

$5^{\text {a) }}$ Derecho subjetivo perfecto de las personas protegidas. Se establece que: "El ingreso mínimo vital se configura como el derecho subjetivo a una prestación de naturaleza económica que garantiza un nivel mínimo de renta a quienes se encuentren en situación de vulnerabilidad económica en los términos que se definen en el presente real decreto-ley. A través de este instrumento se persigue garantizar una mejora de oportunidades reales de inclusión social y laboral de las personas beneficiarias" (art.2. Concepto y naturaleza.1). Lógicamente, es un derecho subjetivo perfecto a la prestación económica (y vale decir también a las accesorias) cuando se acreditan los requisitos exigidos legalmente, porque se trata de una medida condicionada a un déficit de recursos económicos del sujeto o de la unidad de convivencia tomada como supuesto de hecho de la norma.

Su orientación es decididamente universalista y regida por un principio de automaticidad, no se requieren los requisitos instrumentales de afiliación, alta y cotización. Sí, acreditar la residencia y la situación de necesidad en los términos exigidos por la ordenación legal. La ordenación legal distingue entre personas beneficiarias (art. 4 LIMV: a) Las personas integrantes de una unidad de convivencia en los términos establecidos legalmente; b) las personas de al menos 23 años y menores de 65 años que viven solas, o que compartiendo domicilio con una unidad de convivencia en los supuestos del art. 6.2.c), no se integran en la misma, siempre que concurran determinados requisitos explícitamente previstos) y personas titulares (art. 5 LIMV: "las personas con plena capacidad de obrar que la soliciten y la perciban, en nombre propio o en nombre de una unidad de convivencia. En este último caso, la persona titular asumirá la representación de la citada unidad. La solicitud deberá ir firmada, en su caso, por todos los integrantes de la unidad de convivencia mayores de edad que no se encuentren incapacitados judicialmente") del IMV, que pueden no coincidir.

Sujetos titulares también los extranjeros, conforme al art. 19 ("Acreditación de los requisitos") "La residencia legal en España se acreditará mediante la inscripción en el registro central de extranjeros, en el caso de nacionales de los Estados miembros de la Unión Europea, Espacio Económico Europeo o la Confederación Suiza, o con tarjeta de familiar de ciudadano de la Unión o autorización de residencia, en cualquiera de sus modalidades en el caso de extranjeros de otra nacionalidad". Este requisito puede plantear graves problemas sobre todo respecto de las personas migrantes en situación administrativa irregular; y hay que tener en cuenta que muchas de estas personas están realizando trabajos precarios que los sitúa abiertamente dentro de esa categoría de marginalidad que suele llamarse "trabajadores pobres". Esta exclusión puede ser 
criticable desde la perspectiva de los derechos sociales y del principio de igualdad y no discriminación; y desde luego plantea el gran problema de erradicar el trabajo informal o irregular (que para el jurista es típicamente un trabajo en condiciones de ilegalidad y contrario al "trabajo decente" o digno). Hay que tener en cuenta la lógica in fine que inspira a artículos como el 36.5 de la Ley Orgánica 4/2000, de 11 de enero, sobre derechos y libertades de los extranjeros en España y su integración social. Pero también el art. 2 ter ("Integración de los inmigrantes").

$6^{\text {a) }}$ Carácter condicionado al nivel de rentas obtenidas por el sujeto o la unidad de convivencia. No se trata, por tanto, de una renta básica incondicionada como derecho de ciudadanía plena e indiferenciada en relación a situación económica de las personas destinatarias. Es, así, de un sistema de renta mínima basado en la solidaridad social bajo en condicionamiento de la comprobación de recursos de la persona individual o de la unidad de convivencia.

$\left.7^{a}\right)$ Medida de carácter permanente dentro del Catálogo de prestaciones NO contributivas del Sistema de Seguridad Social. Lo cual se comprende porque atiende a situaciones de necesidad social consideradas institucionalmente como de carácter estructural aunque agravadas por la crisis social generada por la pandemia del Covid-19. Ciertamente, esta medida se adapta "En desarrollo del art. 41 de la Constitución Española, y sin perjuicio de las ayudas que puedan establecer las comunidades autónomas en el ejercicio de sus competencias, el ingreso mínimo vital forma parte de la acción protectora del sistema de la Seguridad Social como prestación económica en su modalidad no contributiva". (art.2. 2 Concepto y naturaleza).

$\left.8^{\mathrm{a}}\right)$. La acción protectora se resuelve en una prestación económica que se fijará y se hará efectiva mensualmente en los términos establecidos en la LIMV y en sus normas de desarrollo (por establecer todavía).

En cuanto a la determinación de la cuantía mensual de la prestación de IMV que corresponde a la persona individual o a la unidad de convivencia vendrá determinada por la diferencia entre la cuantía de la renta garantizada, según lo establecido en la LIMV y su normativa de desarrollo, y el conjunto de todas las rentas e ingresos de la persona beneficiaria o de los miembros que componen esa unidad de convivencia del ejercicio anterior, en los términos establecidos en los artículos 8, 13 y 17, siempre que la cuantía resultante sea igual o superior a 10 euros mensuales (art. 10).

Implícitamente se consagra un Principio de adecuación social finalista respecto de la cuantía económica del IMV. Lo cual se expresa en dos sentidos: por un lado, la un ingreso mínimo garantizado que se califica de "vital", lo que indica que quiere garantizar no simplemente un nivel de "subsistencia" en la cobertura de las necesidades, sino un nivel digno de vida, aunque ciertamente se expresa con una cuantía de intensidad mínima. En segundo lugar, el principio de adecuación social finalista se expresa en la ordenación normativa al señalar que: "Se articula en su acción protectora diferenciando según se dirija a un beneficiario individual o a una unidad de convivencia, en este caso, atendiendo 
a su estructura y características específicas" (art. 3.a) del RD-Ley 20/2020). Es importante señalar que la norma elude el concepto de "familia" (que de por sí ya ha adquirido un alcance más amplio abarcando distintos de tipos de familia con diversos modos de formalización jurídica, las llamadas de "hecho" también están "juridificadas") 93, aunque evidentemente lo comprende en el más amplio concepto normativo de "unidad de convivencia", conforme a la delimitación imperativa realiza ex art. 6 (Unidad de convivencia), que establece un concepto legal general al que se añaden una serie de excepciones tipificadas como tales que confirma ese concepto y regla general. El concepto general se expresa en los siguientes términos: "Se considera unidad de convivencia la constituida por todas las personas que residan en un mismo domicilio y que estén unidas entre sí por vínculo matrimonial o como pareja de hecho en los términos del art. 221.2 del texto refundido de la Ley General de la Seguridad Social, o por vínculo hasta el segundo grado de consanguinidad, afinidad, adopción, y otras personas con las que conviva en virtud de guarda con fines de adopción o acogimiento familiar permanente" (art. 8.1). Por su parte, se establece un "como excepción" a la regla anterior una serie de supuestos específicos de "consideración de unidad de convivencia a los efectos previstos en este real decreto-ley" (art. 8.2). El carácter excepcional supone que no admite nuevas inclusiones, ni tampoco interpretaciones extensivas, ni analógicas exorbitantes del fin explicitado en la normativa ${ }^{94}$.

$\left.9^{a}\right)$ Carácter no sustitutivo respecto de las medidas de "ayuda social" (la técnica de ayuda es la que se utilizó para que las Comunidades Autónomos pudiesen asumir competencias en materia de rentas mínimas de inserción, o ingresos de solidaridad o salario social, que con distintas denominaciones han ido evolucionando hacia una asistencia social moderna que reconoce derechos subjetivo a las prestaciones económicas y serviciales dispensadas $)^{95}$. En cualquier caso, está pendiente a través de la normativa reglamentaria que el real decreto-ley prevé, llevar a cabo una racionalización de la articulación entre ésta y otras ayudas.

$10^{\mathrm{a}}$ ) Medida de carácter subsidiario, pues sólo actúa, cuando se está por debajo del nivel mínimo de ingresos que se garantiza, por un lado, y por otro, cuando se esté por debajo de ese nivel mínimo sólo se completa hasta llegar a él; y asimismo cuando se reciben otras prestaciones como, por ejemplo, las rentas mínimas de inserción. En efecto, se dispone que: el IMV “Garantiza un nivel mínimo de renta mediante la cobertura de la diferencia existente entre la suma de los recursos económicos de cualquier naturaleza de

\footnotetext{
${ }^{93}$ El estudio más completo que se ha realizado en nuestro País sobre la protección social de la familia es, sin la menor duda, el realizado en ASOCIACIÓN ESPAÑOLA DE SALUD Y SEGURIDAD SOCIAL: Protección a la familia y Seguridad Social. Hacia un nuevo modelo de protección sociolaboral, 2 Tomos, Congreso Internacional y XV Congreso Nacional de la AESSS, celebrado en Madrid, octubre de 2018, publicado en Murcia, ed. Laborum, 2018.

${ }^{94}$ Para los límites intrínsecos de la interpretación analógica véase ATIENZA RODRÍGUEZ, M.: Sobre la analogía en el Derecho. Ensayo de análisis de un razonamiento jurídico, Madrid, ed. Civitas, 1986, espec., págs. 15 y sigs., y 179 y sigs.

${ }_{95}$ El carácter complementario y no sustitutivo de una renta de subsistencia estatal respecto de las rentas mínimas autonómicas había sido mantenido por la MONEREO PÉREZ, J.L.: La renta mínima garantizada. De la renta mínima a la renta básica, Albacete, ed. Bomarzo, 2018, pág. 111.
} 
que disponga la persona beneficiaria individual o, en su caso, los integrantes de una unidad de convivencia, y la cuantía de renta garantizada para cada supuesto en los términos del art. 10" (art. 3.a) del RD-Ley 20/2020).

$11^{\text {a) }}$ En cuanto a la duración es potencialmente indefinida atendiendo a la misma duración/superación de la situación de necesidad objetiva objeto de cobertura (cuestión distinta es que si tiene éxito y se supera la situación de necesidad fijada en el nivel mínimo de rentas legalmente establecido, desaparecerá el presupuesto de hecho de la norma y con el el derecho actual de la RMV, sin perjuicio de que el sujeto pueda actualizar ese derecho si vuelve a encontrarse en cualquier momento ante la situación de necesidad.

$12^{\mathrm{a}}$ ) Condicionalidad. Incorpora una posición de deber jurídico recíproco, que se refleja en los requisitos de acceso (art. 7 LIMV), en la indicación de los deberes que los sujetos protegidos asumen en el desenvolvimiento dinámico del disfrute de la prestación y en el régimen de infracciones y sanciones (artículos 33 y 34 LIMV). Por un lado, del sujeto protegido sobre el que recaen "cargas" anudadas al derecho relativas a la aceptación de ofertas de trabajo adecuado y a actividad formativas o de reciclaje profesional. Por también conlleva, al mismo tiempo, el deber público de poner todos los medios necesarios para facilitar la incorporación al mercado de trabajo (vinculado al derecho al trabajo). Por consiguiente: la "activación" adquiere una doble vertiente, subjetiva del sujeto para esa puesta a disposición, y objetiva del poder público/Administración pública actuante para poner los medios adecuados para garantizar la inclusión social y el derecho al trabajo.

$13^{\mathrm{a}}$ ) Incorporación de medidas proactivas, las cuales tienen que ver con el objetivo básico de superación de las situaciones de falta de integración en la sociedad (señaladamente, pobreza o marginalidad "descalificadora") o de exclusión social por el trabajo (su falta o insuficiencia dada su precariedad manifiesta). En efecto, se indica que IMV "Se configura como una red de protección dirigida a permitir el tránsito desde una situación de exclusión a una de participación en la sociedad. Contendrá para ello en su diseño incentivos al empleo $y$ a la inclusión, articulados a través de distintas fórmulas de cooperación entre administraciones" públicas (art. 3.d). Pese a carácter modesto, el IMV se corresponde las nuevas necesidades y técnicas emergentes de la Seguridad Social "pasiva" a la "Activa" (el Estado Social Activo) El dato normativo es que este tipo de "derechos sociales" prestacionales se reconfiguran como derechos sociales "condicionados" al cumplimiento de deberes jurídicos de actuación adicionales por parte de los sujetos protegidos o beneficiarios ${ }^{96}$. Estas medidas proactivas son fundamentales,

\footnotetext{
${ }^{96}$ En la perspectiva histórica del desarrollo diacrónico de las políticas de Seguridad Social, puede consultarse, MONEREO PÉREZ, J.L.: "Los (pre)supuestos histórico-institucionales de la Seguridad Social en la constitución social del trabajo", en ROJAS RIVERO, G. (Coord.): Orígenes del contrato de trabajo y nacimiento del Sistema de Protección Social, Albacete, ed. Bomarzo, 2012, Cap. 4. págs. 271 y sigs.; ampliamente, Ibid., Los orígenes de la Seguridad Social en España. José Maluquer y Salvador, Granada, ed.Comares (Col. Crítica del Derecho), 2007, passim.
} 
y no deben considerarse como simples medidas de acompañamiento (aunque están poco enfatizadas en la ordenación reglamentaria se previsible y deseable que se concreten).

Conforme al art. 3. d) LIMV, el IMV precisamente "se configura como una red de protección dirigida a permitir el tránsito desde una situación de exclusión a una de participación (activa) en la sociedad. Contendrá para ello en su diseño incentivos al empleo y a la inclusión, articulados a través de distintas fórmulas de cooperación entre administraciones". Lo que, es obvio, presupone la suscripción de un compromiso por parte de los sujetos protegidos, generador de deberes u obligaciones jurídicas asumidas al acceder a la prestación que condicionan el derecho (lo que puede dar lugar a la suspensión del derecho ex art. 14, o incluso a la extinción del mismo ex art. 15).

Se contempla la promoción de estrategias de inclusión de las personas beneficiarias del ingreso mínimo vital, en coordinación con todas las administraciones involucradas. Asimismo, se prevé la firma de convenios con otros órganos de la administración, con comunidades autónomas y entidades locales, pudiendo estos convenios regir la cooperación en el procedimiento administrativo, en el desarrollo de estrategias de inclusión o en cualquier otro ámbito de relevancia para los fines del ingreso mínimo vital.

El programa de IMV deberá fomentar la resilencia de la persona o unidad de convivencia protegida-más allá de la necesaria labor de supervisión-. La resilencia confiere poder y capacidad para resistir y recuperarse de la situación de vulnerabilidad derivada de la pobreza o exclusión social desde el punto de vista de las personas y en vista a la imagen que de ellas se proyecta en la sociedad de inclusión, inclusiva.

14a) El IMV es intransferible: "No podrá ofrecerse en garantía de obligaciones, ni ser objeto de cesión total o parcial, compensación o descuento, retención o embargo, salvo en los supuestos y con los límites previstos en el artículo 44 del texto refundido de la Ley General de la Seguridad Social, aprobado por Real Decreto Legislativo 8/2015, de 30 de octubre" (art. 3.6).

$15^{\mathrm{a}}$ ) Por último, el IMV es compatible con el trabajo. Es más: el modelo legal promueve esa compatibilidad, pues lo que desea es la inclusión social a través del trabajo, no desincentivarlo. Adviértase que IMV pretende ser, una medida de estructura jurídica y finalista compleja que combina medidas pasivas (prestación económica que garantice un nivel de subsistencia digno, situada en la dirección de garantizar el derecho a la existencia) y medidas activas (formación/capacitación profesional y mecanismos que propician la incorporación o reinserción en el mercado de trabajo, en la línea de garantizar el derecho al trabajo). En este sentido se la puede calificar como una nueva y típica renta activa de inserción. El art. 8. 3, establece que "A efectos de este real decreto-ley, no computarán como ingresos los salarios sociales, rentas mínimas de inserción o ayudas análogas de asistencia social concedidas por las comunidades autónomas, y otros ingresos y rentas de acuerdo con lo previsto en el art. 18" ("Cómputo de los ingresos y patrimonio"). Por su parte, se añade en el apartado 4 que "Con el fin de que la percepción del ingreso mínimo vital no desincentive la participación en el mercado laboral, la 
percepción del ingreso mínimo vital será compatible con las rentas del trabajo o la actividad económica por cuenta propia de la persona beneficiaria individual o, en su caso, de uno o varios miembros de la unidad de convivencia en los términos y con los límites que reglamentariamente se establezcan. En estos casos, se establecerán las condiciones en las que la superación en un ejercicio de los límites de rentas establecidos en el punto 2 del presente artículo por esta causa no suponga la pérdida del derecho a la percepción del ingreso mínimo vital en el ejercicio siguiente. Este desarrollo reglamentario, en el marco del diálogo con las organizaciones empresariales y sindicales más representativas, prestará especial atención a la participación de las personas con discapacidad y las familias monoparentales. 5. Reglamentariamente se podrán establecer, para supuestos excepcionales de vulnerabilidad que sucedan en el mismo ejercicio, los supuestos y condiciones en los que podrán computar los ingresos y rentas del ejercicio en curso a los efectos de acceso a esta prestación”. Comentar, adicionalmente, que no sólo se trata de evitar que se des-incentive la incorporación al mercado de trabajo (lo cual se sitúa, quiérase o no, en una lógica de "activación subjetiva"), sino también el aspecto positivo -y menos de control disciplinario- consistente en el fomento del trabajo como derecho de integración social (art. 35.1 CE), lo cual se sitúa en una lógica garantista de "activación objetiva". Es harto significativo que la Exposición de Motivos destaque la idea de activación y los mecanismos de control posible del fraude; aunque, ciertamente, no descuida la idea-fuerza de la inclusión social por el trabajo profesional. La compatibilidad con el trabajo es importante para evitar el "riesgo moral" de que la IMV actúe como como un desincentivo para aceptar una oferta de trabajo adecuado (y no lo es tanto si es poco remunerado) y contrarrestar la "trampa de la pobreza" y la "trampa de la precariedad". La compatibilidad trabajo-IMV pretende evitar ese "riesgo moral" entre posibles costes de transacción.

Queda pendiente, todavía, una reflexión sobre la mejora de esta nueva medida de protección social -IMV- para alcanzar sus fines idóneos (por el momento se residencia más en las situaciones de extrema necesidad, cuando habría que esperar más que se avanzara hacia una renta mínima garantiza condicionada que vaya más allá de la lógica del "mínimo vital" para penetrar en una lógica de fomento de la integración social plena, aunque sin alcanzar todavía el objetivo utópico -que no significa irrealizable- de una renta básica universal "incondicionada"), lo cual implica, entre otras cosas, la mejora de su cuantía y la racionalización interna de las prestaciones no contributivas del sistema de Seguridad Social. Al tiempo habrá que racionalizar todas las prestaciones mínimas del sistema de protección social en los niveles no contributivos y asistenciales, con las prestaciones familiares y su conexión con el importe del salario mínimo interprofesional; sin que se afecte al nivel o vector contributivo profesional que tiene su lógica propia, incluida la noción de "suficiencia contributiva" referenciada a las rentas de activo dejadas de percibir con los correctivos correspondientes ${ }^{97}$. Por el momento las prestaciones por

\footnotetext{
${ }^{97}$ MONEREO PÉREZ, J.L.: La renta mínima garantizada. De la renta mínima a la renta básica, Albacete, ed. Bomarzo, 2018, espec., Capítulo 3.2. "La propuesta de racionalización a través de la reconducción de
} 
hijo o menor a cargo han sido integradas en el IMV (Disposición transitoria séptima). Pero a la par que el IMV se convierte en una más intensa renta mínima garantizada de carácter también condicionado, el proceso de racionalización de las prestaciones no contributivas y asistenciales deberá ir avanzando. Siempre que se respete el mantenimiento de la Seguridad Social Contributiva y su catálogo de prestaciones, pues nuestro modelo de Seguridad Social no es "residual" sino "institucional" orientada en el nivel contributiva a dispensar prestaciones próximas a las rentas de activo (concepto de suficiencia contributiva, frente a la noción de suficiencia no contributiva y asistencial que atiende ante todo a garantizar una subsistencia digna sin necesidad de otorgar prestaciones equivalentes a las rentas de activo) $)^{98}$.

Parece que el legislador es consciente de la necesidad de una mejora, y del inicio a la parte de todo un proceso de racionalización del conjunto de prestaciones basadas ante todo en técnicas de ayuda social (prestaciones no contributivas y mecanismos asistenciales). Pues se prevé que con el objetivo de evitar duplicidades de cara al ciudadano y en aras de una mayor efectividad de la política, la puesta en marcha del ingreso mínimo vital exigirá también una progresiva reordenación del conjunto de ayudas estatales cuyos objetivos se solapan con los de esta nueva política. Este proceso de reajuste se iniciará con la eliminación de la actual prestación de la Seguridad Social por hijo o menor acogido a cargo sin discapacidad o con discapacidad inferior al 33 por ciento. La progresiva reorganización de las prestaciones no contributivas que deberá abordarse en los próximos años permitirá una focalización en colectivos particularmente vulnerables que contribuya a una mayor redistribución de la renta y la riqueza en nuestro país. Desde esta perspectiva, el IMV supone el inicio de un proceso de reorganización de las técnicas de ayuda de nuestro modelo general de protección social pública.

Por otra parte, esta importante medida de garantía de ingresos -que opera como un estabilizador social y permite instaurarla con carácter homogéneo en toda España-, está lejos todavía de ser suficiente, pero va a dejar vacíos de cobertura protectora. Hay que proseguir en esta línea hacia una más completa renta mínima garantizada a nivel estatal, incluso yendo más allá de la relevante -pero inactuada- iniciativa legislativa popular (ILP), que fue propuesta por los dos sindicatos más representativas de nuestro país. Y ello con independencia de que se refuercen los distintos mecanismos de garantías de rentas contributivas (desempleo y jubilación, señaladamente), cuya intensidad o calidad protectora debe mejorar para homologarnos con otros países europeos de referencia comparables al nuestro. Existe una alta cronificación del desempleo en una horquilla letal porque el desempleo de larga duración afecta a jóvenes y personas maduras. En este sentido el IMV actúa como suelo de protección social respecto de la pobreza y situaciones

las rentas mínimas autonómicas en el Sistema de Seguridad Social: la creación de una renta mínima garantizada a nivel estatal", págs. 98 y sigs.

${ }^{98}$ MONEREO PÉREZ, J.L.: "Derecho a la Seguridad Social (Artículo 41 CE)", en VV.AA.: Comentarios a la Constitución Socio-Económica de España, Monereo Pérez, J.L., Molina Navarrete, C. y Moreno Vida, M.N. (Dirs. y Coords.), Granada, ed. Comares, 2002, págs. 1425-1524; Ibid., "Dignidad de la persona y protección social en la Constitución de 1978: balance y propuestas de reforma para la mejora de sus garantías de suficiencia como derecho social fundamental", en RTSS. CEF. Núm. 429 (diciembre 2018). 
extremas de exclusión social, sobre el cual $-\mathrm{y}$ sin perjuicio de otras prestaciones complementarias- las comunidades autónomas podrían intervenir con carácter complementario conforme a sus necesidades y posibilidades de recursos. Pero si se quiere evitar el "estigma de la pobreza" -la "trampa de la pobreza" que impide salir de ella- es necesario impulsar políticas activas de empleo 99.

Pero el IMV constituye un paso histórico en si ya muy relevante para avanzar hacia una renta mínima garantiza suficiente en términos de intensidad protectora en el sentido previsto en el art. $41 \mathrm{CE}$, por referencia al estándar multinivel de garantía de los derechos de Seguridad Social a que remite en vía interpretativa el art. 10.2 CE. Permitirá atenuar o paliar-que no a superar en términos satisfactorios- la situación de mayor desigualdad de ingresos en comparación con otros Estados Europeos de referencia. Existe una alta cronificación del desempleo en una horquilla letal porque el desempleo de larga duración afecta a jóvenes y personas maduras. En este sentido el IMV actúa como suelo de protección social respecto de la pobreza y situaciones extremas de exclusión social, sobre el cual $-\mathrm{y}$ sin perjuicio de otras prestaciones complementarias- las comunidades autónomos podrían intervenir con carácter complementario conforme a sus necesidades y posibilidades de recursos. Pero si se quiere evitar el "estigma de la pobreza" -la "trampa de la pobreza" que impide salir de ella- es necesario impulsar políticas activas de empleo $^{100}$.

La Europa Social de los Derechos, no puede quedarse sólo en palabras, entre las medidas que garanticen una Europa social y cohesionada debe estar la aprobación de una Directiva Marco sobre Rentas Mínimas, que garantice con fuerza normativa vinculante y desde el Derecho Social Comunitario ingresos mínimos adecuados a todas las personas $-\mathrm{y}$ a las personas que formen parte de su familia o unidad de convivencia- en la UE. Con ello se garantiza también "el derecho a tener derechos" en el sentido de Hannah Arendt ${ }^{101}$.

\section{5.-Balance y perspectivas y propuestas de mejora en el plano técnico-jurídico y de política del Derecho.}

En definitiva, la creación de una RMI de ámbito estatal era cada vez más necesaria. Por otra parte, la implantación de la RMI a nivel estatal es constitucionalmente legítima y tiene amparo en la normativa internacional. La base constitucional para el establecimiento de una renta mínima garantizada o renta mínima de inserción a nivel estatal está

\footnotetext{
${ }^{99}$ Un estudio completo y exhaustivo, en VV.AA.: Las políticas activas de empleo: Configuración y Estudio de su regulación jurídica e institucional, Monereo Pérez, J.L., Fernández Bernat, J.A. y López Insua, B.M. (Dirs. y Coords.), Cizur Menor (Navarra), 2016, 1086 págs.

${ }^{100}$ Un estudio completo y exhaustivo, en VV.AA.: Las políticas activas de empleo: Configuración y Estudio de su regulación jurídica e institucional, Monereo Pérez, J.L., Fernández Bernat, J.A. y López Insua, B.M. (Dirs. y Coords.), Cizur Menor (Navarra), 2016, 1086 págs.

${ }^{101}$ En este sentido MONEREO PÉREZ, J.L.: La renta mínima garantizada. De la renta mínima a la renta básica, Albacete, ed. Bomarzo, 2018, págs. 118-119.
} 
legitimada, justificada y adecuadamente en los artículos $41,9.2$ y $149.1 .17^{\text {a }}$ de la Constitución (y todas ellas interpretadas con arreglo al garantismo multinivel que se impone deducir del art. 10.2 CE), para la protección de las personas frente a situaciones necesidad no adecuadamente satisfechas por otros instrumentos de protección social pública (señaladamente, las rentas mínimas de inserción de las CC.AA) ${ }^{102}$, con cargo a Presupuestos Generales del Estado (como ocurre con las prestaciones no contributivas o con la renta activa de inserción en el marco de la protección por desempleo). Nuestro texto constitucional ex art. 41 y normas concordantes del bloque constitucional de la Seguridad Social configura un sistema mixto de Seguridad Social, con ámbitos contributivos y asistenciales o no contributivos, y con una marcada orientación a realzar el elemento o dimensión asistencialista o no contributivo. Es visible la plasmación de la tendencia hacia la universalización subjetiva y objetiva o prestacional pública y la consagración explicita del principio de suficiencia vinculado a la calidad de las prestaciones dispensadas por sistema de Seguridad Social en su doble y heterogénea dimensión contributiva y asistencial.

Esta nueva prestación de Seguridad Social "Asistencialista" o "no contributiva", aparte de que puede ser completada por las CCAA, no impide la subsistencia de las rentas mínimas autonómicas si estas lo considerasen oportuno reclamando su competencia en materia de asistencia social garantizada constitucionalmente; o, en su caso, su facultad de dictar una "legislación no básica". La instauración de esta renta mínima garantizada (acompañada en la esfera del Derecho Laboral por una política del Derecho cuyo objetivo sea el pleno empleo y la orientación hacia el "trabajo garantizado", decente o digno de la persona que trabaja; esto es, en contraposición con el trabajo precario) puede permitir completar las redes de la protección social pública atendiendo de modo más eficiente y equitativo a la tutela de las situaciones de necesidad vinculadas al desempleo prolongado y a la exclusión social. Se trata de un subsidio condicionado a la situación de necesidad y la disponibilidad de recursos del sujeto protegido; un subsidio que, por supuesto, es necesariamente compatible con la realización de políticas activas de pleno empleo para todos. Se trata de garantizar el derecho a la existencia digna de una parte de la población des-calificada socialmente como "población excedente" situada en los márgenes de la estructura social, sin excluir (más bien presuponer a medio/largo plazo) que en un futuro pudiera avanzarse reflexivamente hacia una Renta Básica o Ingreso Básico incondicionado universalista, que implicaría una refundación más intensa, en cierto

\footnotetext{
${ }^{102}$ Aparte de los grandes textos internacionales que proclaman el derecho a la existencia digna, resulta harto significativo que el "Proyecto de Código para la armonización de las legislaciones nacionales europeas de Seguridad Social”, elaborado en la Universidad de Lovaina (Bélgica) en 1977, establecía en su art. 4 que toda persona tiene derecho a "una renta mínima adecuada que le permita un existencia humana y digna", añadiendo después que tal derecho se genera para las personas que se hallen en circunstancias tales que no les permita disponer de una renta mínima, esto es, un nivel de recursos económicos necesarios para subvenir a la satisfacción de las necesidades más elementales o básicas de una existencia humana y digna (art. 39). Por otra parte, debe anotarse que, con reiteración, el Parlamento Europeo ha aprobado varias resoluciones donde se recomienda que se "estimule la instauración en todos los Estados miembros de una renta mínima garantizada para favorecer la inserción de los ciudadanos más pobres en la sociedad" (Resoluciones de 16 de septiembre y de 16 de noviembre de 1988, de 15 de marzo y de 22 de noviembre de 1989, etcétera).
} 
sentido, de los actuales sistemas de protección social pública y del propio Estado Social de Derecho.

La exigencia de este tipo de rentas de subsistencia y de inserción laboral se impone frente al problema estructural -y no sólo coyuntural- de lucha contra la pobreza y la exclusión social, ante las consecuencias de la "Revolución 4." (Cuarta Revolución Industrial) o las situaciones derivadas de Pandemias sanitarias o de las consecuencias negativas del cambio climático o el deterioro medioambiental. Es la era de la inseguridad social creciente y, en relación a ello, de la redefinición de los sistemas de protección social pública. Y en un contexto de progresivo vaciamiento (por no decir, desmantelamiento; cuando no intentos de deslegitimación) de las instituciones de la solidaridad social propias del Estado Social redistributivo e integrador ante la implantación de una sociedad de mercado de competencia generalizada.

La renta mínima garantizada se configura como derecho subjetivo de Seguridad Social (una nueva prestación no contributiva de carácter pro-activo por su orientación hacia la reinserción profesional y social) y, por tanto, gozando de la necesaria justiciabilidad a través del orden social de la jurisdicción ${ }^{103}$. La renta mínima garantizada puede ser una vía para la protección de las personas en edad de trabajar sin protección por desempleo o de personas en situación de riesgo de pobreza o exclusión social y supondrá un reforzamiento del sistema de protección social clásico del Estado social. Se configura como una prestación de Seguridad Social en su ámbito no contributivo o asistencial, con financiación íntegramente estatal y con cargo a imposición general. La prestación de renta mínima garantizada o ingresos mínimos será, de este modo, una prestación de último recurso -red de seguridad- a la que se accede tras agotar las prestaciones contributivas o

\footnotetext{
${ }^{103}$ Puede consultarse, MONEREO PÉREZ, J.L.: La renta mínima garantizada. De la renta mínima a la renta básica, Albacete, Ed. Bomarzo, 2018, págs. 98 y sigs.; MONEREO PÉREZ, J.L. y MOLINA NAVARRETE,C: El derecho a la renta de inserción, cit.; MONEREO PÉREZ, J.L.: "La renta de "subsistencia". En especial, la renta de inserción como derecho social", en VV.AA.: La jurisprudencia constitucional en materia laboral y social en el período 1999-2010. Libro homenaje a María Emilia Casas, Baylos Grau, A.P., Cabeza Pereiro, J., Cruz Villalón, J., Valdés Dal-Ré, F. (Coords.), Madrid, Ed. La Ley, 2015, págs. 713-755; SUÁREZ CORUJO, B.: "Una prestación de renta mínima garantizada: reflexiones sobre su encaje competencial en el marco constitucional", en Revista de Información Laboral, núm. 10 (2014), págs. 49-60, el cual descarta por sus inconvenientes adicionales, de carácter técnico y de política del Derecho, las otras dos opciones posibles, a saber: una Ley de Armonización de las rentas mínimas autonómicas por el cauce del art. 150.3 CE y la vía del art. 149.1.1 ${ }^{\text {a }} \mathrm{CE}$. Las dos organizaciones sindicales más representativas, CCOO y UGT han acometido una Iniciativa Legislativa Popular, proponiendo el establecimiento de una "Prestación de Ingresos Mínimos" o "Rentas mínimas garantizadas", que asegure unos recursos económicos básicos a todas las personas residentes legales en España, en edad laboral, que queriendo trabajar no pueden hacerlo, que no tengan derecho a prestaciones de desempleo y carezcan de recursos que les permitan vivir con dignidad. Para garantizar su universalidad se ha propuesto como una prestación de la Seguridad Social en su ámbito no contributivo, cuya financiación debe garantizarse vía impuestos, a través de los Presupuestos Generales del Estado. Se trata de una prestación común para todo el Estado, compatible con las competencias en materia de asistencia social de las CCAA. Esta figura sería distinta a la Renta Básica de ciudadanía, esto es, una asignación económica pública de carácter incondicional dirigida a toda la población. En realidad, hay tres propuestas novedosas para abordar los problemas del desempleo (masivo y estructural y derivado de la precariedad laboral) y la pobreza masiva y desigualdad social o desventaja social extrema, a saber: la Renta Mínima de Inserción (la renta mínima garantizada), la Renta Básica de ciudadanía o ingreso de ciudadanía universal, y el Trabajo Garantizado.
} 
asistenciales de desempleo o, en su caso, por no haber podido generar derecho a las mismas. El objetivo de la prestación de renta mínima garantizada es proteger adecuadamente a quienes queriendo y pudiendo trabajar carecen de empleo y sufren una situación de necesidad económica. La medida tendrá naturaleza estructural o permanente en su cristalización normativa, no coyuntural. Se percibirá por la persona afectada de forma indefinida mientras se mantenga la situación de necesidad y tendrá una línea "proactiva", combinando el subsidio no contributivo con políticas activas de empleo.

La creación de una renta mínima garantiza a nivel estatal en la coyuntura actual (y como posible $-y$ no exento de controversia- paso intermedio hacia el establecimiento a más largo plazo -de manera particularmente meditada- de una renta incondicionada o ingreso de ciudadanía) deriva de la constatación de las insuficiencias del tradicional sistema de protección por desempleo (prestación contributiva y subsidios asistenciales) y del conjunto heterogéneo e inorganizado de rentas mínimas autonómicas actualmente vigentes ${ }^{104}$. La renta mínima garantizada será, verdaderamente, el último recurso de la red de seguridad de los sistemas de protección social pública. En el marco de la Unión Europea se está discutiendo sobre la implantación de una "renta mínima europea" (Véase el Dictamen del Comité Económico y Social Europeo sobre la "Renta mínima europea e indicadores de pobreza" (Dictamen de iniciativa)", 2014/C 170/04), aprobado en sesión plenaria de 10 de diciembre de 2013). El CESE subraya la acuciante necesidad de garantizar una renta mínima adecuada en la Unión Europea mediante una Directiva Marco dirigida a combatir la pobreza facilitando la inclusión en el mercado de trabajo, tal y como han solicitado el Comité de las Regiones y varias organizaciones de lucha contra la pobreza, e insta a la Comisión a emprender una acción concertada que responda a la Resolución adoptada por el Parlamento Europeo en 2011 (Resolución del Parlamento Europeo, de 15 de noviembre de 2011, sobre la plataforma europea como la pobreza y la exclusión social (2011/2052(INI), DO C 153E de 31.5.2013, 57-78). La renta mínima garantizada es una ayuda a los ingresos que no está basada en el pago de cotizaciones y que proporciona una red de seguridad para las personas que no pueden optar a las prestaciones de la Seguridad Social. Como última salvaguarda contra la pobreza, está indisolublemente unida al derecho a llevar una vida digna de las personas que no tiene otra forma de asegurar sus ingresos y al de las personas que están a su cargo (familiares, o miembros de la "unidad de convivencia"). La renta mínima garantizada no debe confundirse con el "salario mínimo", que se fija por medio de la legislación o por medio de los convenios colectivos. (Otras políticas distintas al respecto son: a) una renta básica universal, que es una ayuda permanente, de cuantía fija, que se paga a intervalos preestablecidos a cada ciudadano adulto, independientemente de su situación económica o social o de su disponibilidad para el trabajo; y b) un impuesto negativo sobre la renta, basado en el concepto de tipo impositivo marginal). La medida es compatible con otras iniciativas de la lucha contra la pobreza y la desigualdad a través de otros tipos de medidas

\footnotetext{
${ }^{104}$ Rentas Mínimas de Inserción, actualmente existentes, que son, sin duda, legítimas al amparo del título competencia autonómico en materia de asistencia social (art. 148.1. 20ª CE) y tanto más después de la amplitud competencia que autoriza la doctrina establecida por la 239/2002, de 11 de diciembre.
} 
de reforma legislativas, como señaladamente a través de la fiscalidad progresiva y su gestión por la Agencia Tributaria.

El fundamento principal de la renta mínima garantizada europea estaría en el art. 34. 3 en relación con el art. 1 que establece que "la dignidad humana es inviolable. Será respetada y protegida"- de la Carta de los Derechos Fundamentales de la Unión Europea (con rango normativo asimilado al de los tratados fundamentales de la Unión ex art. 6.1 TUE), conforme al cual "con el fin de combatir la exclusión social y la pobreza, la Unión reconoce y respeta el derecho a una ayuda social y a una ayuda de vivienda para garantizar una existencia digna a todos aquellos que no dispongan de recursos suficientes". Para el CESE los nuevos regímenes de renta mínima debería ir acompañados de políticas generales y disposiciones específicas, como las políticas activas del mercado laboral, destinadas a ayudar a las personas sin empleo a reincorporarse en el mercado de trabajo, servicios de colocación, una gestión de las prestaciones y los programas relativos al mercado laboral, como la formación y la creación de empleo apoyadas por estrategias de activación adecuadas, para dar mayores oportunidades a las personas en busca de empleo. Son esenciales, asimismo, unos organismos eficaces de organización del mercado laboral, atención sanitaria y políticas de vivienda, así como servicios públicos asequibles y accesibles de gran calidad ${ }^{105}$. El establecimiento de una renta mínima de inserción permitiría combatir la pobreza y ciertos niveles de desigualdad, e incluiría junto a las ayudas o subsidios económicos la aplicación de políticas activas de empleo, sin que, por tanto, entre en juego el prejuicio de que la medida pueda desincentivar la búsqueda de empleo por parte de los sujetos protegidos.

Su implantación se situaría en la línea de política del Derecho impulsada por el denominado Pilar Europeo de los Derechos Sociales, pero yendo más allá de una mera convergencia de objetivos para abrazar un línea de armonización comunitaria de rentas mínimas garantizadas. A tiempo, tras un periodo de experimentación del modelo de solidaridad social condicionada y selectiva (RMI y fórmulas similares) habría que avanzar hacia la implantación de una renta básica universal e incondicional (sin prueba de recursos y sin contrapartidas), que completase el Sistema de Protección Social del Estado Social de Derecho; es decir, un modelo de solidaridad social incondicional y universal. Es un nuevo modelo de solidaridad social introducido en el corazón del Estado Social de Derecho. Se trataría de una garantía contra la exclusión social y de defender la libertad real para todos. Esta técnica de protección social formaría parte de las condiciones materiales de la libertad (garantizando sólo en parte las condiciones materiales de la existencia de los individuos), y será posible confirmar nuevamente y en la práctica que la generosidad de las transferencias o prestaciones sociales no constituye

\footnotetext{
${ }^{105}$ Sobre este alcance del art. 34.3 CDFUE, véase MONEREO PÉREZ, J.L.: "Seguridad Social y Ayuda Social (Artículo 34)", en VV. AA.: La Europa de los Derechos. Estudio Sistemático de la Carta de los Derechos Fundamentales de la Unión Europea, Monereo Atienza, C. y Monereo Pérez, J.L. (Dirs. y Coords.), Granada, Ed. Comares, 2012, págs. 893 y sigs.
} 
un desincentivo para trabajar (ni generalizable ni sustancialmente relevante) ${ }^{106}$. La implantación como un nuevo derecho social de desmercantilización de las personas en todos los ámbitos donde se desarrolla su personalidad y dignidad humana debe ser el objetivo principal de un renovado Estado Social de Derecho.

El Dictamen del Comité Económico y Social Europeo (CESE), "Por una Directiva marco europeo sobre la renta mínima" [Dictamen de iniciativa], aprobada en pleno $\mathrm{n}^{\circ}$. 541, el 20. 02.2019 ${ }^{107}$, apuesta una por una decidida implantación de una Directiva marco europea sobre la renta mínima. Su punto de partida es ahora más contundente, pues se indica que los textos fundamentales de la Unión y sus compromisos, como la Estrategia Europa 2020, que pretende reducir en veinte millones el número de personas en riesgo de pobreza, no han arrojado los resultados esperados. La aplicación del principio de subsidiariedad, con el método abierto de coordinación (MAC) como único instrumento, resulta por tanto insuficiente para alcanzar los objetivos fijados. Establecer un marco europeo vinculante para una renta mínima decente en Europa que permita generalizar, apoyar y convertir en decentes (adecuados) los sistemas de renta mínima de los Estados miembros constituiría, por tanto, una primera respuesta europea importante al grave y persistente problema de la pobreza en Europa.

La renta mínima decente en Europa a través de un instrumento normativamente vinculante como es la Directiva marco ${ }^{108}$ está justificada por la necesidad de garantizar el acceso a todos los que precisan ayuda y de que esta se adecúe a sus necesidades reales. La renta mínima decente es también un instrumento al servicio de la integración/reintegración laboral de las personas excluidas y de la lucha contra el fenómeno de los trabajadores en situación de pobreza, pese a tener empleo.

Los sistemas de renta mínima hay que concebirlos en términos no de carga sino de inversión social. Los sistemas de renta mínima decente benefician no solo a las personas necesitadas, sino también a la sociedad en su conjunto. Garantizan que las personas que los necesitan se mantengan activas dentro de la sociedad, les ayudan a reconciliarse con el mundo laboral y les permiten vivir dignamente. Unas rentas mínimas decentes son indispensables para conseguir una sociedad más igualitaria, constituyen la base real de la

\footnotetext{
${ }^{106}$ Para la crítica de ese enfoque del discurso del liberalismo radical -que comprende al mathusianismo, al spencerismo social, al darwinismo social y a las diversas versiones del neoliberalismo contemporáneo, puede consultarse, MONEREO PÉREZ, J.L.: El sistema de protección por desempleo en España, Valencia, Ed. Tirant Lo Blanch, 1997; Ibid., «El modelo español de protección contra el desempleo», en VV.AA.: Seguridad Social y Protección social: temas de actualidad, López López, J. (Coord.), Madrid, Marcial Pons, 1996; Ibid., «Los renglones torcidos de la política social moderna: Los derechos sociales a fin de siglo», en Rev. Facultad de Derecho Univ.Gr., núm. 2 (1999); Ibid., "Pobreza, trabajo y exclusión social en la larga duración: una reflexión crítica a partir de Henry George”, en Documentación laboral. Revista de relaciones laborales, economía y sociología del trabajo, y trabajo autónomo, núm. 83-Vol. II (2008), págs. 11-109; Ibid., "La ideología del 'darwinismo social': La política social de Herbert Spencer (I y II), en Documentación Laboral, núm. 87 (2009) y 90 (2010); Ibid., La metamorfosis del Derecho del Trabajo, Albacete, Ed. Bomarzo, 2017, y la bibliografía allí citada.

${ }^{107}$ SOC/585- EESC-2018-02210.00-00-AC-TRA (EN) 1/16- Ponente: Georges Dassis.

${ }^{108} \mathrm{El}$ recurrir a la legislación de la UE encuentra un fundamento jurídico reside en el artículo 153, apartado 1 , letras c) y h), del TFUE.
} 
protección social y garantizan una cohesión social que beneficia a toda la sociedad. Los sistemas de renta mínima apenas representan un porcentaje reducido del gasto social, pero arrojan un retorno de inversión considerable, mientras que la ausencia de inversión tiene repercusiones muy negativas para las personas y conlleva costes elevados a largo plazo. Forman un conjunto de estímulos eficaces, ya que el dinero gastado revierte inmediatamente en la economía, frecuentemente en los sectores que más acusan la crisis. Como resultado de la interacción entre las rentas mínimas y el salario mínimo, también contribuyen a garantizar salarios decentes y a evitar el aumento del número de trabajadores pobres.

En cuanto al modelo de renta mínima o renta de subsistencia se trata de una renta mínima garantizada de carácter condicionado y no de una renta básica universal e incondicionada ${ }^{109}$.

Interesa destacar que ahora se vincula directamente la renta mínima europea con el concepto de trabajo decente impulsado por la OIT. Se ha trabajado ya mucho sobre la renta mínima y se han expresado numerosas posiciones al respecto. Mediante este dictamen, el CESE insiste en el concepto de «renta mínima decente» (ingresos mínimos para llevar una vida digna, por encima del umbral de pobreza), inspirándose en el concepto de «trabajo decente» de la $\mathrm{OIT}^{110}$. De ahí que se haga referencia a una «renta mínima europea decente».

La OIT ha insistido en el contexto de la Pandemia del Covid-19 en la necesidad de la protección de los ingresos de las personas. Añadiendo que "Hay que aplicar reformas institucionales y políticas en profundidad para facilitar la recuperación sobre la base de la demanda y aumentar la resilencia por medio de sistemas de protección social universal eficaces que constituyan factores estabilizadores automáticos en los planos económicos y social frente a la crisis. Ello contribuirá asimismo a recuperar la confianza en las instituciones y en los gobiernos". Por lo demás, se subraya, el Covid-19 tendrá una amplia repercusión en el mercado laboral. Más allá de la inquietud que provoca a corto plazo para la salud de los trabajadores y de sus familias, el virus y la consiguiente crisis económica repercutirán adversamente en el mundo del trabajo en tres aspectos fundamentales: 1) la cantidad de empleo (tanto en materia de desempleo como de subempleo); 2) la calidad del trabajo (con respecto a los salarios y el acceso a protección social); y 3) los efectos en los grupos específicos más vulnerables frente a las consecuencias adversas en el mercado laboral. Es manifiesto que será preciso establecer políticas orientadas al pleno empleo en el marco de una recuperación económica y desde luego poner en valor que los sistemas de protección social refuerzan la resilencia y permiten hacer frente a emergencias a corto plazo en plano social, así como mitigar los

\footnotetext{
${ }^{109}$ Advierte que no se debe confundir el concepto de renta mínima decente, objeto del presente dictamen, con el de renta universal abonada a todos los miembros de una colectividad (municipio, región o Estado) sin requisitos relativos a sus recursos o su situación laboral. Además, aunque la mayoría de los países cuentan con sistemas de renta mínima, aún debe examinarse su adecuación con respecto a las necesidades, ya que en la mayoría de los casos sigue siendo un problema. Alemania y Francia obran en este sentido.

$110 \quad$ http://www.ilo.org/global/topics/decent-work/lang--es/index.htm.
} 
efectos de crisis venideras (y el coronavirus no se ha ido). Los sistemas de Seguridad Social eficaces y eficientes son factores estabilizadores económicos y sociales muy eficaces en los planos económico y social en particular si se implantan antes de que se produzca una crisis. Cabe reconocer nítidamente la función que desempeña la protección social para fomentar la demanda agregada en situaciones de crisis y mitigar las desigualdades sociales que propicia la justicia social y la paz social ${ }^{111}$. De este modo es posible establecer una relación virtuosa entre las medidas sociales (racionalidad social) y las medidas económicas (racionalidad económica) bajo un enfoque integrador propio del Estado Social de Derecho ${ }^{112}$.

A los fundamentos jurídicos ya aludidos se indica que revisten especial importancia las referencias jurídicas de los Tratados, como por ejemplo el art. 3 del TUE, que cita entre los objetivos de la Unión el pleno empleo y el progreso social, pero también la lucha contra la exclusión social y la discriminación y el fomento de la cohesión económica, social y territorial, así como la solidaridad entre los Estados miembros, el art. 9 del TFUE, que precisa que «[e]n la definición y ejecución de sus políticas y acciones, la Unión tendrá en cuenta las exigencias relacionadas con la promoción de un nivel de empleo elevado, con la garantía de una protección social adecuada, con la lucha contra la exclusión social y con un nivel elevado de educación, formación y protección de la salud humana», y, más concretamente, el artículo 151 del TFUE que abre el título $X$ sobre la política social y que menciona como objetivos de la Unión y de los Estados miembros «el fomento del empleo, la mejora de las condiciones de vida y de trabajo, a fin de conseguir su equiparación por la vía del progreso, una protección social adecuada, el diálogo social, el desarrollo de los recursos humanos para conseguir un nivel de empleo elevado y duradero y la lucha contra las exclusiones», objetivos que resultan realizables por la Unión en la medida en que esta (artículo 153, apartado 1, del TFUE) «apoyará y completará la acción de los Estados miembros en los siguientes ámbitos: [...] c) la seguridad social y la protección social de los trabajadores; [...] h) la integración de las personas excluidas del mercado laboral; [...] j) la lucha contra la exclusión social; [y] k) la modernización de los sistemas de protección social $[\ldots] \gg$.

El enfoque de los objetivos a perseguir con esta institución se apoya se apoya en los trabajos de economistas como Amartya $\operatorname{Sen}^{113}$ sobre lo que él mismo denomina «capabilities» (enfoque de las capacidades), compuestas por tres elementos ${ }^{114}$. Lo que

\footnotetext{
111 OIT.: Comunicado de la Organización internacional del Trabajo. Covid-19 y el mundo del trabajo: repercusiones y respuestas, 18 de marzo de 2020. Este Comunicado institucional de la OIT proporciona una evaluación preliminar de las posibles repercusiones del Covid-19 en el mundo del trabajo y se propone un conjunto de medidas a nivel político y jurídico para mitigar esas repercusiones negativas y facilitar una recuperación sólida, eficaz y solidaria.

112 MONEREO PÉREZ, J.L.: La metamorfosis del Derecho del Trabajo, Albacete, ed. Bomarzo, 2017, espec., Cap. IV ("Por un nuevo Derecho del Trabajo garantista en el marco de la construcción de una "Europa Social” basada en la tutela efectiva de los derechos fundamentales"), págs. 213 y sigs.

${ }^{113}$ SEN, A.: La idea de la justicia, Madrid, Ed. Taurus, 2010.

114 Salud/esperanza de vida _ Estudios recientes demuestran que las personas en situación de pobreza ahorran en su atención sanitaria, en particular en la dental. Adoptan un mal estilo de vida, se alimentan peor y, por tanto, padecen más problemas relacionados con la obesidad. Existen diferencias considerables en la 
implica que asume una determinada idea en cuanto a la realización de la justicia social a través de un sistema de derechos y de garantías de las capacidades humanas. Es también el enfoque básicamente análogo que ha mantenido Martha Nussbaum ${ }^{115}$.

También se intuye que la introducción de una renta mínima garantizada podría conducir a una racionalización de las ayudas sociales en determinados países. Y reténgase que se hace referencia a las prestaciones basadas en la ayuda social (técnicas de ayuda que asumen la lógica de la compensación -típicos de la asistencia social y de las prestaciones no contributivas de Seguridad Social- y no la lógica de la sustitución como sería el caso de las prestaciones contributivas de los regímenes profesionales típicos de Previsión y Seguridad Social Contributiva. Este enfoque es, por ejemplo, el que subyace a la propuesta de «renta universal del trabajo» formulada en el plan de lucha contra la pobreza presentado por el presidente de la República Francesa, que pretende «garantizar una base mínima de dignidad a todos los que puedan beneficiarse de ella, fusionando el mayor número de prestaciones sociales». Del mismo modo, el debate iniciado en Alemania sobre la introducción de una renta mínima de solidaridad contribuiría a la lucha contra la pobreza, en particular para los desempleados de larga duración, al simplificar el sistema de ayudas sociales. El Gobierno ya ha reservado 4000 millones de euros con esta finalidad hasta 2021.

Por otra parte, la instauración de una renta básica o ingreso universal no debe ser (en la lógica del reformismo democrático-social) una pretendida alternativa al objetivo irrenunciable del pleno empleo de calidad y a la lucha por el trabajo garantizado, pues se trata de dos objetivos plena y necesariamente compatibles en una perspectiva de profundización en la mejor tradición del constitucionalismo democrático-social con Estado Social Activo ${ }^{116}$. La renta básica -o ingreso básico- incondicional supondría una decisiva reforma modernizadora y de mejora de los actuales sistemas de Estados del Bienestar. Pero no una alternativa sustitutoria de la Seguridad Social contributiva tal como la conocemos, la cual deberá ser mantenida respectando su propia lógica de

esperanza de vida entre ricos y pobres. También es preciso tener en cuenta la dureza del trabajo realizado. Saber/nivel de formación _ Las estadísticas muestran claramente la tasa de desempleo en función de los distintos niveles de formación. Según los datos de Eurostat de 2015, el $11 \%$ de los europeos de entre 18 y 24 años han abandonado el colegio prematuramente. Nivel de vida _ Se trata de integrar todos los elementos de la calidad de vida en un mismo poder adquisitivo y no solo los componentes relativos a la supervivencia alimentaria. La capacidad de movilidad y el acceso a la cultura son elementos importantes de integración/inclusión en la relación con sus congéneres y la sociabilidad, es decir, los medios para no encerrar a las personas pobres en un aislamiento que supone un círculo vicioso de des-socialización.

${ }^{115}$ NUSSBAUM, M.C.: Crear capacidades. Propuesta para el desarrollo humano, Barcelona, Ed. Paidós, 2011; Ibid., Las fronteras de la justicia: consideraciones sobre la exclusión, Barcelona, Ed. Paidós, 2007. ${ }^{116}$ Véase, al respecto, el ensayo de VAN PARIJS, PH.y GENET, M.: "Ingreso universal y pleno empleo: una alianza inevitable", en VV.AA.: El ingreso universal, monográfico de Papeles de la FIM, núm. 7 (1996), págs. 29-39; y ampliamente, VAN PARIJS, PH.: Libertad real para todos (qué puede justificar el capitalismo si hay algo que pueda hacerlo), trad. Francisco Álvarez, Barcelona, Ed. Paidós, 1996; VAN PARIJS,PH. y VANDERBORGHT,Y.: Ingreso básico. Una propuesta radical para una sociedad libre y una economía sensata, trad. Laura Lecuona y Maia F. Miret, México, 2017; RAVENTÓS, D.: Las condiciones materiales de la libertad, Barcelona, Ed. El Viejo Topo, 2007; RAVENTÓS, D. y CASASSAS, D. (Eds.): La renta básica en la era de las grandes desigualdades, Barcelona, Ed. El Viejo Topo, 2011. 
sustitución de las rentas de activo dejadas de percibir durante la etapa de vida activa del sujeto protegido.

La renta básica a nivel de la Unión Europea, finalmente, tendría la virtualidad de hacer más visible la idea -o, mejor, proyecto político) de construir una Europa de los Derechos basada en la garantía de los derechos sociales fundamentales, siendo, ésta, una parte relevante de la base normativa común de una Europa Social como "derecho a la existencia digna de la persona". He aquí la posible emergencia de un welfare post-nacional en el espacio geopolítico de la Unión. Pues, en definitiva, el derecho a una renta básica acaba por asumir la función de un "derecho a tener derechos" en el sentido de Hannah Arendt ${ }^{117}$. Por tanto, estamos ante una institución que va más allá del discurso de implantar una simple "malla de seguridad" - una "última red de protección social"-, pues -sin dejar de ser eso- se sitúa en el marco de una política de rentas que autentificaría una libertad real para todos y el disfrute efectivo del conjunto de los derechos fundamentales.

La Europa social no puede quedar sólo en palabras, entre las medidas que garanticen una Europa social y cohesionada debe estar la aprobación de una Directiva Marco Europea sobre Rentas Mínimas, que garantice con fuerza normativa vinculante y desde el Derecho Social Comunitario ingresos mínimos adecuados a todas las personas -y a las personas que formen parte de su familia o unidad de convivencia- en la UE. La intensificación del proceso de construcción europea afectaría a la viabilidad política y jurídica de la propuesta de avanzar en una modelo social para una Europa Social, que se haga merecedora de esa denominación y con ello merezca una mayor adhesión y legitimación política de los pueblos europeos. Aquí la Unión Europea actuaría como una unión de transferencias redistributivas, siendo la renta básica -o ingreso básico- un pilar para la supervivencia y perfección del llamado modelo social europeo. Y contribuiría a evitar la competitividad basada en las ventajas legislativas de los sistemas de protección social nacionales, es decir, evitaría, en gran medida, la tentación de reducir la protección social dispensada en nombre de la competitividad ${ }^{118}$. Por lo demás, la renta básica no exige desmantelar el resto del sistema de protección social pública, sino tan sólo una racionalización de las prestaciones no contributivas y asistenciales a menudo desorganizadas, superpuestas y desvertebradas. Y a esa racionalización habría que añadir un incremento ponderado del papel de los impuestos en la financiación del sistema (señaladamente en el vector no contributivo del Sistema de Seguridad Social en el que se insertaría la renta mínima garantizada). De nuevo nos encontramos con un problema decisión sustancialmente política, pues de lo que se trata es de cómo acrecentar y distribuir los recursos necesarios para garantizar los derechos sociales y a través de ellos mejorar la vida de las personas ${ }^{119}$. Ello se resuelve, pues, en la exigencia de adaptación

\footnotetext{
${ }^{117}$ ARENDT, H.: La condición humana, Barcelona, Ed. Paidós, 1993; Ibid., Los orígenes del totalitarismo, Madrid, Ed. Taurus, 1998; y basándose en su pensamiento como punto de partida, RODOTÀ, S.: El derecho a tener derechos, Madrid, Ed. Trotta, 2014.

118 VAN PARIJS,PH. y VANDERBORGHT,Y.: Ingreso básico. Una propuesta radical para una sociedad libre y una economía sensata, trad. Laura Lecuona y Maia F. Miret, México, 2017, págs. 296 y sigs.

${ }^{119}$ Aparte de la obra citada en la nota anterior, véase en un sentido parcialmente análogo, BARRY, B.: Why Social Justice Matthers, Cambridge, Polity, 2005, espec., págs. 208 y sigs., en particular pág. 219.
} 
permanente-creativa, y no simplemente reactiva- de las técnicas de protección social a los cambios socio-económicos y tecnológicos en orden la cobertura de las necesidades de las personas.

Eso sí, implicaría, aparte de la racionalización y más acentuado modelo público mixto de financiación, un marco de planificación económico-social que la complete como garantía de ingresos (incluidas esas medidas de fiscalidad progresiva). Es dar cuenta de la preferencia del fin impulsando los medios de para alcanzarlos de viable realización.

Con todo la renta mínima garantizada no es una simple "fórmula mágica" de la ciencia jurídica; es un nuevo instrumento de gestión de lo social necesario para evitar la desprotección efectiva de un cada vez más amplio número de personas expulsadas del mercado de trabajo o en situación de exclusión social o de pobreza (a la que el trabajo precario no es capaz de liberar), que de lo contrario quedarían en la periferia, esto es, en los márgenes de la sociedad.

Al tiempo y tras una larga fase de experimentación de una renta mínima europea y estatal podría pensarse en un objetivo de más largo alcance, a saber: ante los cambios estructurales en curso los Sistemas de Seguridad Social deberían incorporar (en una dirección que permite el art. 34 de la Carta de la UE y las Recomendaciones de la OIT) una nueva rama de prestaciones más ambiciosa y compleja como es la Renta Básica. La implantación de la renta básica universal e incondicionada $(\mathrm{RBU})$ ha encontrado un apoyo en el Consejo de Europa (Resolución 2197/2018, de 23 de enero de 2018, de la Asamblea Parlamentaria del Consejo de Europa y en el Parlamento Europeo (Resolución del Parlamento Europeo, de 24 de octubre de 2017, sobre las políticas encaminadas a garantizar la renta mínima como instrumento para la lucha contra pobreza y la exclusión social). La renta básica aparece como una medida jurídico-institucional necesaria para repensar no sólo la Seguridad Social sino también el Estado del Bienestar en nuestra época el cual debe alcanzar siempre sus objetivos de garantizar el derecho a la existencia digna de la persona a través de una renovación constante de sus instrumentos técnicos organización de las tutelas dispensadas ${ }^{120}$. Esta renta básica o ingreso universal puede ser viable técnicamente y posible desde el punto de vista económico-financiero a condición de que se renueve el pacto social de la postguerra mundial ${ }^{121}$ sobre el alcance de la

\footnotetext{
${ }^{120} \mathrm{El}$ fundamento de esta concepción dinámica del Estado del Bienestar, en MONEREO PÉREZ, J.L.: La renta mínima garantizada. De la renta mínima a la renta básica, Albacete, Ed. Bomarzo, 2017, passim. Ibid., en una perspectiva de larga duración, Derechos sociales de la ciudadanía y ordenamiento laboral, Madrid, Ed. Consejo Económico y Social de España, 1996, espec., págs. 19 y sigs., y 159 y sigs.

${ }^{121}$ La crisis institucional del pacto social de la postguerra, que determinó la construcción de los Estados del Bienestar, es hecho verificado desde hace varias décadas. Puede consultarse, por ejemplo, MERKEL, W.: ¿Final de la socialdemocracia?, Valencia, Edicions Alfons El Magnànim, 1995, págs. 19 y sigs.; MONEREO PÉREZ, J.L.: Derechos sociales de la ciudadanía y ordenamiento laboral, Madrid, Consejo Económico y Social de España, 1996, Segunda Parte ("La crisis del Estado del Bienestar y la revisión de las políticas públicas", con referencia a "la crisis estructural del modelo de Estado del Bienestar keynesiano"), págs. 185 y sigs. Para el advenimiento de la forma "Estado de mercado" en el marco de un capitalismo financiero especulativo, puede consultarse HARVEY, D.: Breve historia del neoliberalismo, Madrid, Ed. Akal, 2007, págs. 73 y sigs.; ALTVATER, E.: El fin del capitalismo tal y como lo conocemos, Barcelona, Ediciones de Intervención Cultural/El Viejo Topo, 2011, págs. 155 y sigs.; MONEREO PÉREZ,
} 
desmercantilización que a través de los derecho sociales ha de garantizada el Estado Social y de recrear los sistemas de Seguridad Social nacionales y fomentar un impulso a la solidaridad en el nuevo horizonte de una "economía-mundo" que ha alcanzado el nivel que conocemos de "globalización", en cuyo marco se ha ampliado el "mercado-mundo" que tiende a la mercantilización y re-mercantilización de las protecciones sociales estructuradas principalmente en el ámbito nacional. Es ésta una nueva expresión por la lucha permanente en una sociedad democrática por garantizar la seguridad de la existencia de la cuna a la tumba para todas las personas (el ideal de Beveridge más allá de sus limitaciones liberales); el necesario impulso hacia una mayor redistribución de la renta que añada a los mecanismos estándar tradicionales una prestación consistente en la renta básica universal e incondicionada, la cual tiene la virtualidad de garantizar un cierto nivel de desmercantilización y con ello también una autonomía básica de las personas. Se comprenderá, así, que esta medida, lejos de una idea utópica ingenua, podría permitir en unión con otras- la renovación (o si se quiere reinvención) del modelo de Estado Social contemporáneo en una sociedad cada vez más fragmentada y compleja en su estructuración y en un contexto de construcción y dominio del capitalismo global ${ }^{122}$, que hace visible un largo giro del capitalismo de postguerra al neoliberalismo ${ }^{123}$. Y todo ello, se insiste, sin pretender en absoluto que sea una alternativa a las prestaciones de la Seguridad Social contributiva: una gestión de la reducción por reemplazo de éstas por esta nueva renta garantizada universalista e incondicional no parece deseable, ni tampoco factible en una sociedad democrática que la rechazaría. Por lo demás, hay que tener en cuenta que los fenómenos a los que responde no son coyunturales, ni pasajeros en gran medida, sino un producto de nuestra época que hunde sus raíces en la exclusión y marginación social crecientes de amplias capas de la población que evidencia una desconexión y ruptura de la sociedad entre los de abajo y los de arriba; un fenómeno que introduce una fractura desestabilizadora tanto desde la perspectiva social como desde la política, y que debilita profundamente los pilares en los que se sustentan las democracias constitucionales. Esta medida merece ser considera seriamente como una de las alternativas posibles a la crisis sociales realmente existente y la que se intuye en el porvenir de instauración de un mundo neoliberal. El derecho a una renta básica -así concebido- es un elemento importante de un proyecto de política del Derecho encaminado hacia la reconstrucción de la sociedad civilizada.

J.L.: Espacio de lo político y orden internacional. La teoría política de Carl Schmitt, Barcelona, Ediciones de Intervención Cultural/El Viejo Topo, 2015, págs.460 y sigs.

${ }^{122}$ Es suficiente reparar en las reflexiones de STIGLITZ, J.: El precio de la desigualdad, Madrid, Ed. Taurus, 2012. Raventós hace referencia a la renta básica como una de las condiciones materiales de la libertad real. Véase RAVENTÓS, D.: Las condiciones materiales de la libertad, Barcelona, Ediciones de Intervención Cultural/El Viejo Topo, 2007.

${ }^{123}$ STREECK, W.: Comprando tiempo. La crisis pospuesta del capitalismo democrático, Buenos AiresMadrid, Kartz Editores, 2016, págs. 38 y sigs., 59 y sigs., y 99 y sigs.; PIKETTY, T.: El capitalismo en el siglo XXI, Madrid, Fondo de Cultural Económica de España, 2014. 


\section{Bibliografía.}

ALFONSO MELLADO, L.C., JIMENA QUESADA, L. y SALCEDO BELTRÁN, M.C.: La jurisprudencia del Comité Europeo de Derechos Sociales frente a la crisis económica, Albacete, Ed. Bomarzo, 2014.

ALTVATER, E.: El fin del capitalismo tal y como lo conocemos, Barcelona, Ediciones de Intervención Cultural/El Viejo Topo, 2011.

AÑON ROIG, M.J.: "Derecho a un nivel de vida adecuado y medios de subsistencia", y MONEREO PÉREZ, J.L.: "Derecho a la Seguridad Social y Asistencia Social”, ambos en VV.AA.: El Sistema Universal de los Derechos Humanos, Monereo Atienza, C. y Monereo Pérez, J.L. (Dirs. y Coords.), Granada, Ed. Comares, 2014, págs. 543 y sigs. y 625 y sigs., respectivamente.

ARENDT, H.: La condición humana, Barcelona, Ed. Paidós, 1993.

ASOCIACIÓN ESPAÑOLA DE SALUD Y SEGURIDAD SOCIAL: Protección a la familia y Seguridad Social. Hacia un nuevo modelo de protección sociolaboral, 2 Tomos, Congreso Internacional y XV Congreso Nacional de la AESSS, celebrado en Madrid, octubre de 2018, publicado en Murcia, ed. Laborum, 2018.

ATIENZA RODRÍGUEZ, M.: Sobre la analogía en el Derecho. Ensayo de análisis de un razonamiento jurídico, Madrid, ed. Civitas, 1986.

BADEL, M.: "La lutte contre les exclusions en droit français le rôle des minima sociaux. Rapport France", en VV.AA.: La exclusión social: Estudio comparado desde la perspectiva jurídica laboral y constitucional, QUINTANILLA NAVARRO, R.Y. (Dir.), MATEOS Y DE CABO, Ó.I. (Coord.), Madrid, Universidad Rey Juan Carlos, 2018, págs. 317-337.

BECK, U.: La sociedad del riesgo. Hacia una nueva modernidad, Barcelona, Ed. Paidós, 1998.

CASTEL, R. El ascenso de las incertidumbres, Buenos Aires, FCE, 2010.

CASTELLS, M.: La era de la información: economía, sociedad y cultura, 3 Vols., Madrid, 1996-2003.

FERRAJOLI, L.: Derechos y garantías. La ley del más débil, trad. P. Andrés Ibañez y A. Greppi, Madrid, Ed. Trotta, 1999.

FERRAJOLI, L.: La democracia a través de los derechos. El constitucionalismo garantista como modelo teórico y como proyecto político, trad. P. Andrés Ibañez, Madrid, Ed. Trotta, 2014.

FERRAJOLI, L.: Poderes salvajes. La crisis de la democracia constitucional, Prólogo y traducción de P. Andrés Ibáñez, Ed. Trotta, 2011. 
FERRAJOLI, L.: Principia iuris. Teoría del derecho y de la democracia. 1. Teoría del derecho, trad. J. C. Bayón, P. Andrés Ibañez, A. Ruiz Miguel, L. Prieto Sanchís, Madrid, Ed. Trotta, $2^{a}$ ed., 2016

GARCÍA ROMERO, B.: Rentas mínimas garantizadas en la Unión Europea, Madrid, CES, 1999.

HARVEY, D.: Breve historia del neoliberalismo, Madrid, Ed. Aka, 2007.

HARVEY, D.: La discriminación negativa, trad. A. Martínez-Riu, Barcelona, Ed. Hacer, 2010

LÓPEZ INSUA, B.M.: La protección social de las personas inmigrantes: un modelo garantista, Barcelona, Ed. Atelier, 2020.

LUHMAN, N.: Sociología del riesgo, México, Universidad Iberoamericana, $3^{\mathrm{a}}$ ed., 2006,

MARX, K. y ENGELS, F.:. Crítica del Programa de Gotha \& Crítica del Programa de Erfurt [1875-1891], en Obras Escogidas, edición y estudio preliminar, "Marxismo y racionalidad crítica en la larga duración” (pp. XI-LXX), a cargo de J.L. Monereo Pérez, Granada, Ed. Comares (Col. Crítica del Derecho), 2012.

MÉDA, D.: El Trabajo: Un valor en peligro de extinción, Barcelona, Ed. Gedisa, 1998.

MENGER,A.: El derecho al producto íntegro del trabajo \& El Estado democrático del trabajo, edición y estudio preliminar, "Derechos sociales y Estado democrático social en Anton Menger” (pp. IX-LXXVIII), a cargo de J. L. Monereo Pérez, Granada, Ed. Comares (Col. Crítica del Derecho), 2004.

MONEREO PÉREZ, J.L. y DÍAZ-AZNARTE, T.: El Estado Social Autonómico, Albacete, Ed. Bomarzo, 2008. MONEREO PÉREZ, J.L.: "La Carta comunitaria de derechos sociales fundamentales de los trabajadores" (I) y (II), en Revista Española de Derecho del Trabajo. Civitas, núms. 56-57 (1992-1993), núm. 57 (1993), espec., págs. 85 y sigs.

MONEREO PÉREZ, J.L. y MOLINA NAVARRETE, C.: El derecho a la renta de inserción. Estudio de su régimen jurídico, Granada, Ed. Comares, 1999.

MONEREO PÉREZ, J.L., y LOPEZ INSUA,B.M.: "La garantía internacional del derecho a un "trabajo decente", en Nueva Revista Española de Derecho del Trabajo, núm. 177, 2015, págs. 27-72.

MONEREO PÉREZ, J.L.: La dignidad del trabajador. Dignidad de la persona en el sistema de relaciones laborales, Murcia, Ed. Laborum, 2019.

MONEREO PÉREZ, J.L.: "Trabajo decente y prestaciones ante situaciones de necesidad. Desempleo y políticas de activación e inserción", en VV.AA. monereo pérez, j.l; gorelli 
hernández, j y de val tena, á (dirs) y lópez insua, b.m (coord). El trabajo decente, Granada, Ed. Comares, 2018.

MONEREO PÉREZ, J.L.: "Derecho a la Seguridad Social (Artículo 41 CE)", en VV.AA.: Comentarios a la Constitución Socio-Económica de España, Monereo Pérez, J.L., Molina Navarrete, C. y Moreno Vida, M.N. (Dirs. y Coords.), Granada, ed. Comares, 2002, págs. 1425-1524.

MONEREO PÉREZ, J.L.: "Derecho a la Seguridad Social y Asistencia Social (art. 22 DUDH; art. 9 PIDESC)", en VV.AA.: El sistema Universal de los Derechos Humanos, Monereo Atienza, C. y Monereo Pérez, J.L. (Dirs. y Coords.), Granada, ed. Comares, 2014, págs. 515 y sigs.

MONEREO PÉREZ, J.L.: "Derecho al Trabajo (Artículo 1 de la Carta Social Europea)", y MONEREO PÉREZ, J.L.y LÓPEZ INSUA, B.M.: "Derecho a unas condiciones equitativas (artículo 2)", ambos en VV.AA.: La garantía multinivel de los derechos fundamentales en el Consejo de Europa. El Convenio Europeo de Derechos Humanos y la Carta Social Europea, Monereo Atienza, C. y Monereo Pérez, J.L. (Dirs. y Coords.), Granada, Ed. Comares, 2017, págs. 361 y sigs., y 395 y sigs., respectivamente.

MONEREO PÉREZ, J.L.: "Derechos a la Seguridad Social (Artículo 12 de la Carta Social Europea Revisada)", en VV.AA.: La garantía multinivel de los derechos fundamentales en el Consejo de Europa. El Convenio Europeo de los Derechos Humanos y la Carta Social Europea, Monereo Atienza, C. y Monereo Pérez, J.L. (Dirs. y Coords.), Granada, ed. Comares, 2017, págs. 629 y sigs.

MONEREO PÉREZ, J.L.: "Dignidad de la persona y protección social en la Constitución de 1978: balance y propuestas de reforma para la mejora de sus garantías de suficiencia como derecho social fundamental", en RTSS. CEF. Núm. 429 (diciembre 2018).

MONEREO PÉREZ, J.L.: "El derecho a la Seguridad Social (Art. 41 CE)”, en VV.AA.: Comentario a la Constitución Socio-Económica de España, Monereo Pérez, J.L., Molina Navarrete,C. y Moreno Vida, M.N. (Dirs. y Coords.), Granada, Ed. Comares, 2002.

MONEREO PÉREZ, J.L.: "El sistema español de protección por desempleo: Eficacia, equidad y nuevos enfoques", y LÓPEZ INSUA, B.M.: "La renta activa de inserción como instrumento de lucha contra la exclusión social", en VV.AA. La Protección por desempleo en España. XII Congreso Nacional de la Asociación Española de Salud y Seguridad Social, Murcia, Ed. Laborum, 2015, págs. 125 y sigs., y 385 y sigs., respectivamente.

MONEREO PÉREZ, J.L.: "La garantía internacional y europea de los derechos a la Seguridad Social y Asistencia Social”, en VV.AA.: Estudios sobre Seguridad Social. Libro Homenaje al Profesor José Ignacio García Ninet, Madrid, ed. Atelier, 2017, págs. 187-245. 
MONEREO PÉREZ, J.L.: "La renta de "subsistencia". En especial, la renta de inserción como derecho social", en VV.AA.: La jurisprudencia constitucional en materia laboral y social en el período 1999-2010. Libro homenaje a María Emilia Casas, Baylos Grau, A.P., Cabeza Pereiro, J., Cruz Villalón, J., Valdés Dal-Ré, F. (Coords.), Madrid, Ed. La Ley, 2015, págs. 713-755.

MONEREO PÉREZ, J.L.: "La renta Mínima para las familias sin recursos", en ASOCIACIÓN ESPAÑOLA DE SALUD Y SEGURIDAD SOCIAL: Protección a la familia y Seguridad Social. Hacia un nuevo modelo de protección sociolaboral, II Congreso Internacional y XV Congreso Nacional de la AESSS, celebrado en Madrid, octubre de 2018, publicado en Murcia, ed. Laborum, 2018, págs. 831 y sigs.

MONEREO PÉREZ, J.L.: "Los (pre)supuestos histórico-institucionales de la Seguridad Social en la constitución social del trabajo”, en ROJAS RIVERO, G. (Coord.): Orígenes del contrato de trabajo y nacimiento del Sistema de Protección Social, Albacete, ed. Bomarzo, 2012, págs. 203-328.

MONEREO PÉREZ, J.L.: "Los (pre)supuestos histórico-institucionales de la Seguridad Social en la constitución social del trabajo", VV.AA. Orígenes del contrato de trabajo y nacimiento del Sistema de Protección Social, Rojas Rivero, Gl. (Coord.), Albacete, Ed. Bomarzo, 2012.

MONEREO PÉREZ, J.L.: "Los derechos a la Seguridad Social y a la Ayuda Social (Artículo 34)", en VV.AA.: La Europa de los derechos. Estudio sistemático de la Carta de los Derechos Fundamentales de la Unión Europea, Monereo Atienza, C. y Monereo Pérez, J.L. (Dirs. y Coords.), Granada, Ed. Comares, 2012, págs. 893 y sigs.

MONEREO PÉREZ, J.L.: "Los derechos sociales fundamentales ante las recientes reformas: un desafío para el trabajo decente", y VEGA RUIZ, M.L.: "El futuro del trabajo: ¿Regular un derecho humanos? El debate sobre la centralidad del ser en el trabajo", en VVAA.: El futuro del derecho del trabajo y de la seguridad social en un panorama de reformas estructurales: Desafios para el trabajo decente, Congreso Internacional de Granada, Monereo Pérez, J.L., Túlio Barroso, F., Las Heras, H. (Dirs.), Moreno Vida, M.N. y Maldonado Molina, J.A. (Coords.), Murcia, Ed. Laborum, 2018, págs. 27-84, y págs. 11-26, respectivamente.

MONEREO PÉREZ, J.L.: "Pilar Europeo de Derechos Sociales y Sistemas de Seguridad Social”, en Lex Social. Revista de Derechos Sociales, Vol. 8, Núm. 2, 2018, págs. 251298.

MONEREO PÉREZ, J.L.: "Pobreza, trabajo y exclusión social en la larga duración: una reflexión crítica a partir de Henry George”, en Documentación laboral, núm. 83 (2008), págs. 11-109. 
MONEREO PÉREZ, J.L.: "Pobreza, trabajo y exclusión social en la larga duración: una reflexión crítica a partir de Henry George”, en revista Documentación Laboral, núm. 83 (2008), págs. 11-109.

MONEREO PÉREZ, J.L.: "Seguridad Social y Ayuda Social (Artículo 34)", en VV. AA. La Europa de los Derechos. Estudio Sistemático de la Carta de los Derechos Fundamentales de la Unión Europea, Monereo Atienza, C. y Monereo Pérez, J.L. (Dirs. y Coords.), Granada, Ed. Comares, 2012, págs. 893 y sigs.

MONEREO PÉREZ, J.L.: "Seguridad Social y ayuda social" (Artículo 34 de la Carta de la UE)", en VV.AA.: La Europa de los Derechos. Estudio Sistemático de la Carta de los Derechos Fundamentales de la Unión Europea, Monereo Atienza, C. y Monereo Pérez, J.L. (Dirs. y Coords.), Granada, ed. Comares, 2012, págs. 893 y sigs.

MONEREO PÉREZ, J.L.: «El modelo español de protección contra el desempleo», en VV.AA.: Seguridad Social y Protección social: temas de actualidad, López López, J. (Coord.), Madrid, Marcial Pons, 1996.

MONEREO PÉREZ, J.L.: «Genealogía de las Declaraciones de Derechos y su significación político-jurídica», estudio preliminar a JELLINEK,G. La declaración de los Derechos del Hombre y del ciudadano, Granada, Ed.Comares, 2009.

MONEREO PÉREZ, J.L.: Derechos sociales de la ciudadanía y ordenamiento laboral, Madrid, Ed. Consejo Económico y Social de España, 1996.

MONEREO PÉREZ, J.L.: El sistema de protección por desempleo en España, Valencia, Ed. Tirant Lo Blanch, 1997.

MONEREO PÉREZ, J.L.: Espacio de lo político y orden internacional. La teoría política de Carl Schmitt, Barcelona, Ediciones de Intervención Cultural/El Viejo Topo, 2015.

MONEREO PÉREZ, J.L.: La dignidad del trabajador. Dignidad de la persona en el sistema de relaciones laborales, Murcia, ed. Laborum, 2019.

MONEREO PÉREZ, J.L.: La metamorfosis del Derecho del Trabajo, Albacete, ed. Bomarzo, 2017.

MONEREO PÉREZ, J.L.: La protección de los derechos fundamentales. El modelo europeo, Albacete, Ed. Bomarzo, 2009.

MONEREO PÉREZ, J.L.: La renta mínima garantizada. De la renta mínima a la renta básica, Albacete, Ed. Bomarzo, 2018.

MONEREO PÉREZ, J.L.: La teoría crítica social de Thorstein Veblen: sociedad opulenta y empresa de negocios, Granada, Ed. Comares (Col. Crítica del Derecho), 2010.

MONEREO PÉREZ, J.L.: Los orígenes de la Seguridad Social en España. José Maluquer y Salvador, Granada, Ed. Comares, 2007. 
MONEREO PÉREZ, J.L.: Los orígenes de la Seguridad Social en España. José Maluquer y Salvador, Granada, ed.Comares (Col. Crítica del Derecho), 2007.

MONEREO PÉREZ, J.L.: "Refundar el ordenamiento laboral para juridificar plenamente el principio de justicia social y el trabajo decente", en Lex Social. Revista jurídica de los derechos sociales, Vol. 9, núm. 1 (2019), págs. 220-294.

MONEREO PÉREZ, J.L.: "Seguridad Social y Ayuda Social (Artículo 34 de la Carta de la UE)", en VV.AA.: La Europa de los Derechos. Estudio sistemático de la Carta de los Derechos Fundamentales de la Unión Europea, Monereo Atienza, C. y MONEREO PÉREZ, J.L. (Dirs. y Coords.), Granada, Ed. Comares, 2012, págs. 893 y sigs.

MONEREO PÉREZ, J.L.: La dignidad del trabajador. Dignidad de la persona en el sistema de relaciones laborales, Granada, Ed. Laborum, 2019.

MONEREO PÉREZ, J.L.:. Modernidad y capitalismo. Max Weber y los dilemas de la teoría política y jurídica, Barcelona, Ediciones de Intervención Cultural/El Viejo Topo, 2013.

MONEREO PÉREZ, J.L.y MOLINA NAVARRETE, C.: "La cláusula transformadora: el principio de igualdad de oportunidades", en VV.AA.: Comentario a la Constitución Socio-Económica de España, Monereo Pérez, J.L., Molina Navarrete, C. y Moreno Vida, M.N.(Dirs. y Coords.), Granada, Ed. Comares, 2002, págs. 131 y sigs.

MONEREO PÉREZ, J.L.y ORTEGA LOZANO, P.G.: "Derecho a protección contra la pobreza y la exclusión social (artículo 30 de la Carta Social Europea”, en VV.AA.: La garantía multinivel de los derechos fundamentales en el Consejo de Europa. El Convenio Europeo de Derechos Humanos y la Carta Social Europea, Monereo Atienza, C. y Monereo Pérez, J.L. (Dirs. y Coords.), Granada, Ed. Comares, 2017, págs. 925 y sigs.

NUSSBAUM, M.C.: Crear capacidades. Propuesta para el desarrollo humano, Barcelona, Ed. Paidós, 2011.

NUSSBAUM, M.C.: Las fronteras de la justicia: consideraciones sobre la exclusión, Barcelona, Ed. Paidós, 2007.

OIT. "Declaración de la OIT sobre la justicia social para una globalización equitativa, adaptada por la conferencia Internacional del trabajo en su nonagésima séptima reunión, Ginebra, Oficina Internacional del Trabajo, 10 de junio de 2008.

OIT. Comunicado de la Organización internacional del Trabajo. Covid-19 y el mundo del trabajo: repercusiones y respuestas, 18 de marzo de 2020.

OIT. La iniciativa del centenario relativa al futuro del trabajo. 4 Nota Informativa, Ginebra, OIT, 2019, págs. 1-9. 
OIT: Declaración de la OIT relativa a los principios y derechos fundamentales en el trabajo, adoptada por la Conferencia Internacional del trabajo en su octogésima sexta reunión, Ginebra, Oficina Internacional del Trabajo 18 de junio de 1998 (Anexo revisado, el 15 de junio de 2010), $2^{\text {a }}$ ed., revisada, 2010.

PIKETTY, TH.: El capitalismo en el siglo XXI, Madrid, Fondo de Cultural Económica de España, 2014.

PISARELLO, G. y DE CABO, A. (eds.): La renta básica como nuevo derecho ciudadano, Madrid, Ed. Trotta, 2006.

POLANYI, K.: La Gran Transformación. Crítica del liberalismo económico, Madrid, Ed. La Piqueta, 1989.

POLANYI, K.: La gran transformación. Crítica del liberalismo económico, Madrid, Ed. La Piqueta,1989.

RADBRUCH, G.. El hombre en el Derecho. Conferencias y artículos seleccionados sobre cuestiones fundamentales del Derecho, trad. Aníbal del Campo, revisión, edición, y estudio preliminar, "Gustav Radbruch: un modelo de jurista en el constitucionalismo democrático social" (pp. IX-LXIII), a cargo de J.L. Monereo Pérez, Ed. Comares (Col. Crítica del Derecho), 2020.

RAVENTÓS, D. y CASASSAS, D. (Eds.): La renta básica en la era de las grandes desigualdades, Barcelona, Ed. El Viejo Topo, 2011.

RAVENTÓS, D.: Las condiciones materiales de la libertad, Barcelona, Ediciones de Intervención Cultural/El Viejo Topo, 2007.

REVILLI, M.: Más allá del siglo XX. La política, las ideologías y las asechanzas del trabajo, Barcelona, Ediciones de Intervención Cultural/El Viejo Topo, 2001.

REY PÉREZ, J.L.: El derecho al trabajo y el ingreso básico ¿Cómo garantizar el derecho al trabajo?, Madrid, Ed. Dykinson, 2007.

RIFKIN, J.: El fin del trabajo. El declive de la fuerza del trabajo global y el nacimiento de la era posmercado, Barcelona, Ed. Paidós, 1996.

RODGERS, G. et altri.: La OIT y la lucha por la justicia social, 1919-2009, Ginebra, Oficina Internacional del Trabajo, 2009.

RODOTÀ, S.: El derecho a tener derechos, Madrid, Ed. Trotta, 2014.

SEARLE. J.R.: Razones para actuar. Una teoría del libre albedrío, Oviedo, Ed. Nobel, 2000.

SENNETT, R.: La corrupción del carácter. Las consecuencias personales del trabajo en el nuevo capitalismo, Barcelona, Ed. Anagrama, 2000. 
STANDING, G.: La renta básica. Un derecho para todos y para siempre, Epílogo de Daniel Raventós y Davide Casassas, Barcelona, Ediciones de Pasado y Presente, 2018.

STANDING, G.: La renta básica. Un derecho para todos y para siempre, Epílogo de Daniel Raventós y DavideCasassas, Barcelona, Ediciones de Pasado y Presente, 2018.

STIGLITZ, J.: El precio de la desigualdad, Madrid, Ed. Taurus, 2012.

STREECK, W.: Comprando tiempo. La crisis pospuesta del capitalismo democrático, Buenos Aires-Madrid, Kartz Editores, 2016.

VALLECILLO GÁMEZ, R. y MOLINA NAVARRETE, C.: Empresas de inserción y mercados de trabajo inclusivos, Granada, Ed. Comares, 2008.

VAN PARIJS, PH.: Libertad real para todos (qué puede justificar el capitalismo si hay algo que pueda hacerlo), trad. Francisco Álvarez, Barcelona, Ed. Paidós, 1996.

VAN PARIJS, PH.:Libertad real para todos, trad. Francisco Álvarez, Barcelona, Ed. Paidós, 1996.

VAN PARIJS,PH. y VANDERBORGHT,Y.: Ingreso básico. Una propuesta radical para una sociedad libre y una economía sensata, trad. Laura Lecuona y Maia F. Miret, México, 2017.

VILA TIERNO, F.: "Política de inserción laboral (I. Rentas Mínimas de Inserción)", y GOERLICH PESET, J.M. "Política de inserción laboral (II. Empresas de Inserción)", ambos trabajos en VV.AA. (2016) Las políticas Activas de Empleo: Configuración y Estudio de su regulación jurídica e institucional, Monereo Pérez, J.L., Fernández Berrnat, J.A., López Insua, B.M. (Dirs. y Coords.), Cizur Menor (Navarra), Ed. Thomson/Aranzadi, 2016, págs. 875 y sigs., y 895 y sigs., respectivamente.

VV.AA.: El trabajo decente, Monereo Pérez, J.L., Gorelli Hernández, J. y, De Val Tena, L.A. (Dirs.), López Insua, B.M. (Coord.), Granada, Ed. Comares, 2018.

VV.AA.: Las políticas activas de empleo: Configuración y Estudio de su regulación jurídica e institucional, Monereo Pérez, J.L., Fernández Bernat, J.A. y López Insua, B.M. (Dirs. y Coords.), Cizur Menor (Navarra), 2016, 1086 págs. 